\title{
Early Cretaceous angiosperm leaves from the Dakota Formation, Hoisington III locality, Kansas, USA
}

\author{
Hongshan Wang and David L. Dilcher
}

\begin{abstract}
This study reports the results of an examination of about 1,500 fossil leaf impressions from the Early Cretaceous (Albian) strata at the Hoisington III locality, Kansas, USA. We recognize 24 fossil angiosperm leaf species, of which seven are assignable to the modern orders Illiciales (1), Laurales (4) and Magnoliales (2). Two species show close relationship with modern family Nymphaeaceae. Three species are possibly related to the Chloranthaceae. One species shows affinity with the Nelumbonaceae. Three species are closely related to the Platanaceae. One new genus, Wingia gen. nov., is established. A total of seven new species and new combinations are proposed. They include: Longstrethia aspera (Lesquereux) comb. nov., Sapindopsis powelliana (Lesquereux) comb. nov., Anisodromum schimperi (Lesquereux) comb. nov., Wingia expansolobum (Upchurch and Dilcher) comb. nov., Sapindopsis retallackii sp. nov., cf. Anisodromum upchurchii sp. nov., and Dicotylophyllum skogii sp. nov. Comparisons with the angiosperm leaf assemblages from other localities indicate that the Hoisington locality represents the most species-rich leaf assemblage from the Dakota Formation along the east side of the Cretaceous Western Interior Seaway (KWIS) and equivalent units. The result provides new information for understanding the early diversity and evolution of the angiosperms during the mid-Cretaceous (late Albian - early Cenomanian), a critical time during which angiosperms began a rapid adaptive radiation.
\end{abstract}

Hongshan Wang. Florida Museum of Natural History, University of Florida, Gainesville, Florida 32611, USA. hwang@flmnh.ufl.edu

David L. Dilcher. Department of Earth and Atmospheric Sciences, Indiana University, Bloomington, Indiana 47405, USA. dilcher@indiana.edu

Keywords: new species; new genus; angiosperm; Dakota Formation; Early Cretaceous; Western Interior Seaway (WIS)

Submission: 14 December 2017 Acceptance: 6 June 2018

Wang, Hongshan and Dilcher, David L. 2018. Early Cretaceous angiosperm leaves from the Dakota Formation, Hoisington III locality, Kansas, USA. Palaeontologia Electronica 21.3.34A 1-49. https://doi.org/10.26879/841

palaeo-electronica.org/content/2018/2270-early-cretaceous-leaves

Copyright: September 2018 Palaeontological Association.

This is an open access article distributed under the terms of Attribution-NonCommercial-ShareAlike 4.0 International (CC BY-NC-SA 4.0 ), which permits users to copy and redistribute the material in any medium or format, provided it is not used for commercial purposes and the original author and source are credited, with indications if any changes are made.

creativecommons.org/licenses/by-nc-sa/4.0/ 


\section{INTRODUCTION}

Angiosperm leaves are abundant in the Dakota Formation and its equivalent units along the eastern margin of the Cretaceous Western Interior Seaway. These fossils have been studied since the late $19^{\text {th }}$ century (Lesquereux, 1868, 1872, 1873, 1874, 1876a, 1876b, 1878, 1883, 1892; Newberry, 1868, 1895, 1898; Berry, 1911a, 1911b, 1911c, 1911d, 1916, 1920, 1922a, 1922b, 1923). However, these early publications are biased against mudstone and shale specimens because the specimens studied were primarily collected from various sandstone units of the Dakota Formation. More recent works (Upchurch and Dilcher, 1990; Wang and Dilcher, 2006a, 2009) have turned attention to the fossil plant material from the mudstone and shale units of the Dakota Formation collected by David Dilcher, colleagues, and students since the 1960s. The extensive collection of angiosperm leaf megafossils from many localities in lowa, Kansas, Nebraska, and Minnesota during the past fifty-five years enables the comprehensive survey of the mid-Cretaceous Dakota Formation angiosperms. In this paper, we focus on the systematics of angiosperm leaves from the Lower Cretaceous (upper Albian) Dakota Formation at the Hoisington III locality, Kansas (Figure 1). Many publications have been generated based upon material from this locality (Dilcher, 1979; Crane and Dilcher, 1984; Dilcher and Crane, 1984; Dilcher and Kovach, 1986; Skog et al., 1992; Skog and Hill, 1992; Skog and Dilcher, 1994; Dilcher, 2000). In this study, we examined approximately 1,500 specimens and report 24 fossil species of angiosperm leaves. This research represents the third in a series of detailed studies of the Dakota flora from localities in Kansas, Nebraska, lowa, and Minnesota by the authors (Wang and Dilcher, 2006a, 2009).

\section{MATERIAL AND METHODS}

All specimens discussed in this paper were collected from the Hoisington III locality (UF15706), Barton County, Kansas (Figure 1). The clay pit is about 3.2 kilometers south of Hoisington on State Route 281 at latitude $38^{\circ} 28.31^{\prime} \mathrm{N}$ and longitude $98^{\circ} 46.92^{\prime}$ W. Specimens were collected from the claystone overlying interbedded sandstone and shales of the Terra Cotta Clay Member of the Dakota Formation (Figure 2) that outcropped at the south end of the north clay pit (Figure 3; also see Retallack and Dilcher, 1981b, text-figures 6-8 and Retallack and Dilcher, 2012, figure 2) by David
Dilcher and colleagues Greg Retallack, Karl Longstreth, Carolyn Bagley, and Frank Potter during the field excursions in 1978 and 1979.

Specimens have been assigned the locality number UF15706 and are deposited in the Paleobotany and Palynology collection at the Florida Museum of Natural History (FLMNH), University of Florida, Gainesville, Florida, USA. The locality number is followed by a specimen number (for example, UF15706-8263).

Most specimens are impressions except for a few compressions with poorly preserved cuticle. Descriptions are based on direct observation under a dissecting microscope. Details were enhanced in photographs by using a Nikon D200 digital camera under extreme oblique lighting to highlight the venation patterns.

Farley and Dilcher (1986) interpreted the age of the plant fossil-bearing strata at the Hoisington III locality as Cenomanian (early Late Cretaceous). However, based upon results of palynostratigraphic and sedimentologic analyses, Brenner et al. (2000)

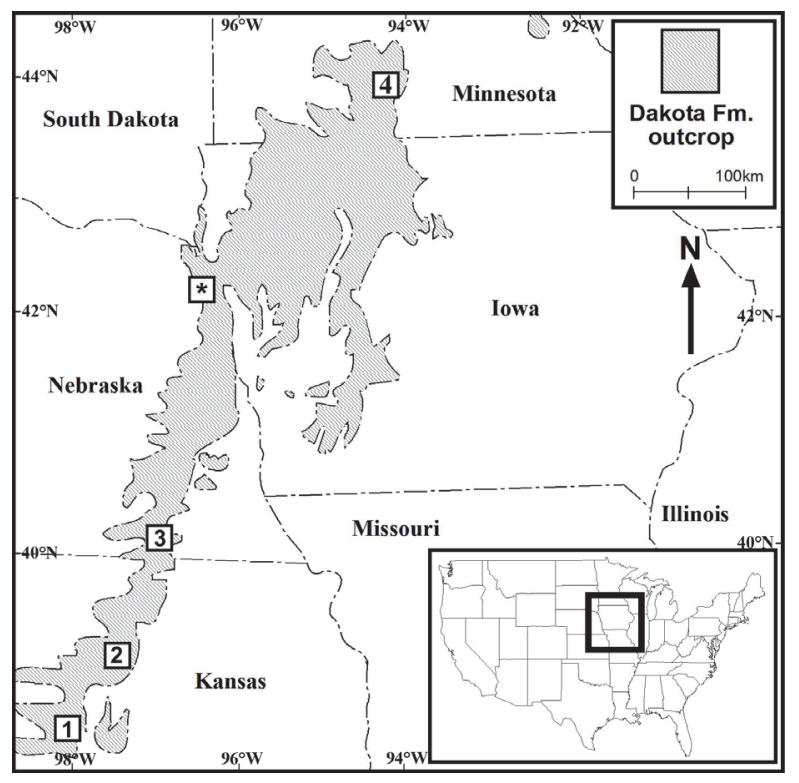

FIGURE 1. Regional outcrop of the Dakota Formation and the location of the Hoisington III locality and other plant megafossil localities discussed in the text. 1, Hoisington III, Kansas (UF 15706); 2, Braun Ranch, Kansas (UF15709); 3, Rose Creek, Nebraska (UF15713); and 4, Courtland I, Minnesota (UF18267). "*” indicates type area of the Dakota Formation. Map extends from southern Minnesota to north central Kansas along the eastern margin of the Western Interior Seaway in the United States. The inset map shows the location of the study area in USA. State boundaries are dashed. Outcrop map is based on figure 1 of Witzke and Ludvigson (1996). 


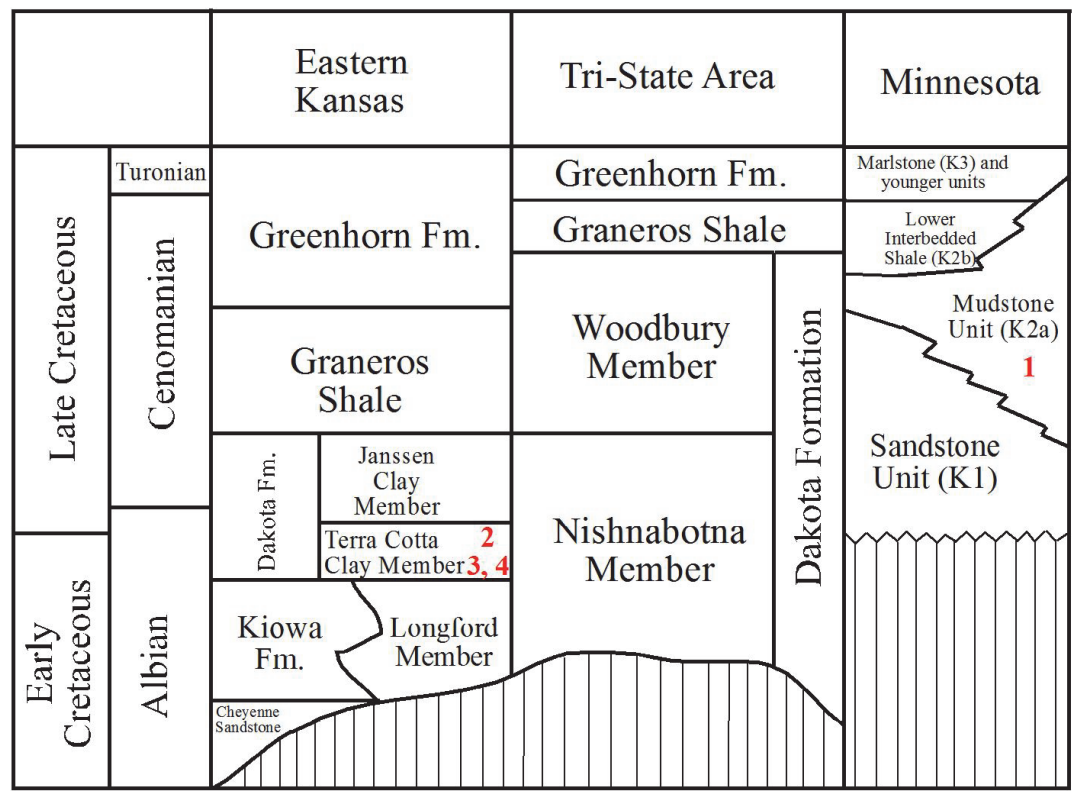

FIGURE 2. Chart shows the Albian, Cenomanian and Turonian stratigraphic units in Kansas, the Tri-state area (lowa, Nebraska, and South Dakota; modified from figure 4 of Brenner et al., 2000), and Minnesota (modified from figure 8 of Setterholm, 1994). 1, Courtland I clay pit, Minnesota; 2, Rose Creek, Nebraska; 3, Braun Ranch, Kansas; and 4, Hoisington III, Kansas.

proposed that the age of this sequence at this locality is late Albian (latest Early Cretaceous). Retallack and Dilcher (1981a, 1981b) interpreted the sedimentary environment at this locality as a brackish water lagoon or fresh water lake with river influence. The interpretation of a predominately fresh water lake was confirmed by the presence of aquatic ferns (Skog et al., 1992; Skog and Hill, 1992; Skog and Dilcher, 1994) and aquatic angiosperms (Wang and Dilcher, 2006b).

We follow Upchurch and Dilcher's (1990) scheme for specific and generic classification and the scheme of Angiosperm Phylogeny Group

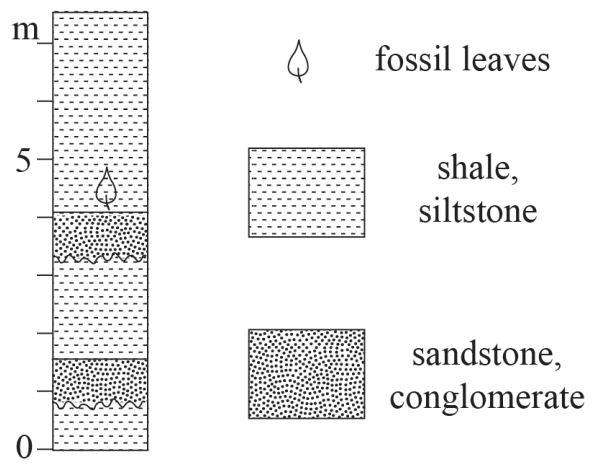

FIGURE 3. Cross section of the plant-bearing layer at the southwest end of the north clay pit at the Hoisington III locality, Kansas (Modified from figure 2 of Retallack and Dilcher, 2012).
$(2009,2016)$ for familial and ordinal classification. Comparisons with other fossil taxa are based primarily on published figures, except most of those published by Lesquereux (1892) which were examined at the Paleobiology Department of the National Museum of Natural History, Smithsonian Institution, Washington D.C., USA. All the type specimens from the Rose Creek locality (Upchurch and Dilcher, 1990), Braun Ranch locality (Wang and Dilcher, 2006a), and Courtland I locality, Minnesota (Wang and Dilcher, 2009) were examined at the Paleobotany and Palynology collection in the Florida Museum of Natural History. Comparisons with extant taxa are based on published illustrations and direct observation on modern leaf collections at the Paleobotany and Palynology collection at the Florida Museum of Natural History.

In the synonym list, we follow Matthews (1973, p. 718) and use the following two symbols to indicate the degree of confidence with which particular items (specimens) in the list are referred to the taxon under discussion: "*” in front of the year indicates that with the publication of this paper, the species can be regarded as valid under the terms of the ICBN; "v." in front of the year indicates that we have checked the deposited specimens that relate to the work cited and because of the evidence of the deposited specimens we are able to take responsibility for this assignment. 
TABLE 1. Occurrences of angiosperm leaf megafossils at the four localities of the Dakota Formation, Braun's ranch, Kansas (Wang and Dilcher 2006a), Hoisington, Kansas, Rose Creek, Nebraska (Upchurch and Dilcher 1990), and Courtland, Minnesota (Wang and Dilcher 2009). A plus sign “+” indicates the presence of a taxon at a locality.

\begin{tabular}{|c|c|c|c|c|}
\hline \multirow{2}{*}{$\begin{array}{c}\text { Taxon } \\
\text { Genus/species }\end{array}$} & \multicolumn{4}{|c|}{ Locality } \\
\hline & Hoisington & Braun Ranch & Rose Creek & Courtland \\
\hline Crassidenticulum decurrens & + & + & + & \\
\hline Crassidenticulum cracendentis & & & & + \\
\hline Crassidenticulum trilobum & + & + & & \\
\hline Crassidenticulum cf. trilobum & + & & & \\
\hline Crassidenticulum landisiae & & + & & \\
\hline Yangia glandifolia & & + & & \\
\hline Densinervum kaulii & & & + & + \\
\hline Landonia calophylla & & & + & \\
\hline Landonia callii & & + & & \\
\hline Aquatifolia fluitans & + & & & \\
\hline Brasenites kansense & + & & & \\
\hline Longstrethia varidentata & & & + & \\
\hline Longstrethia aspera & + & & & \\
\hline Pabiania variloba & + & & + & \\
\hline Setterholmia rotundifolia & & & & + \\
\hline Setterholmia deleta & & & & + \\
\hline Manchesterii macrophylla & & & & + \\
\hline Pandemophyllum kvacekii & & & + & + \\
\hline Pandemophyllum attenuatum & & & + & + \\
\hline Pandemophyllum sp. & & & + & \\
\hline Rogersia dakotensis & + & & & + \\
\hline Rogersia parlatorii & + & + & & \\
\hline Rogersia lottii & & + & & \\
\hline Wolfiophyllum daphneoides & & + & & \\
\hline Wolfiophyllum heigii & & + & & \\
\hline Wolfiophyllum pfaffianum & + & & & + \\
\hline Jarzenia kanbrasota & + & & & + \\
\hline New genus $A$ & & & + & \\
\hline Liriophyllum siemii & & & & + \\
\hline Liriophyllum kansense & + & & & \\
\hline cf. Paleonelumbo macroloba & + & & & \\
\hline Credneria quadrata & & + & & \\
\hline Credneria cyclophylla & + & & & + \\
\hline Dischidus quinquelobus & & + & & \\
\hline Eoplatanus serrata & & + & & \\
\hline
\end{tabular}

Leaf architectural terminology mostly follows Dilcher (1974), Hickey (1973, 1979), Wolfe et al. (1975), and Ellis et al. (2009) with the following exceptions. We use the term leaf and/or leaflet when describing specimens only if the specimens demonstrate enough features to show leaf organization (i.e., simple or compound). Otherwise we use the term lamina in our descriptions. We follow Upchurch and Dilcher (1990) and Upchurch et al. (1994) by using "cf." to indicate minor differences between our specimens and a previously published taxon and a fossil taxon's similarities to modern families. The following abbreviations are used: L/W represents the ratio of leaf, leaflet, or lamina length 
TABLE 1 (continued).

\begin{tabular}{|c|c|c|c|c|}
\hline \multirow{2}{*}{$\begin{array}{c}\text { Taxon } \\
\text { Genus/species }\end{array}$} & \multicolumn{4}{|c|}{ Locality } \\
\hline & Hoisington & Braun Ranch & Rose Creek & Courtland \\
\hline Aspidiophyllum denticulatum & & + & & \\
\hline Sapindopsis powelliana comb. nov. & + & & & \\
\hline Sapindopsis retallackii sp. nov. & + & & & \\
\hline Anisodromum wolfei & + & & + & \\
\hline Anisodromum upchurchii sp. nov. & + & & & \\
\hline Anisodromum schimperi comb. nov. & + & & & \\
\hline Citrophyllum doylei & & & + & \\
\hline Citrophyllum aligera & + & & & \\
\hline Trochodendroides rhomboideus & & & & + \\
\hline Trochodendroides elliptica & & + & & \\
\hline Wingia expansolobum comb. nov. & + & & + & \\
\hline Wingia cf. expansolobum & + & & & \\
\hline Acritodromum ellipticum & & & + & \\
\hline Crepetii minudentis & & & & + \\
\hline Didromophyllum basingerii & & & + & \\
\hline Glandilunatus kansense & & + & & + \\
\hline Gooleria crasseprima & & & & + \\
\hline Hickeyphyllum sandersii & & + & & \\
\hline Hickeyphyllum imhofii & & + & & \\
\hline Kladoneuron gooleri & & + & & \\
\hline Reynoldsiophyllum masonii & & & + & \\
\hline Reynoldsiophyllum nebrascense & & & + & \\
\hline New genus $B$ & & & + & \\
\hline Dicotylophyllum aliquantuliserratum & & & + & \\
\hline Dicotylophyllum angularis & & & + & \\
\hline Dicotylophyllum braunii & & + & & \\
\hline Dicotylophyllum carlsonii & & & & + \\
\hline Dicotylophyllum coughlantii & & & & + \\
\hline Dicotylophyllum fragile & & + & & \\
\hline Dicotylophyllum huangii & & + & & \\
\hline Dicotylophyllum leptovenum & + & & & + \\
\hline Dicotylophyllum myrtophylloides & & & + & \\
\hline Dicotylophyllum rosafluviatilis & & & + & \\
\hline Dicotylophyllum skogii sp. nov. & + & & & \\
\hline Dicotylophyllum tulipiferum & & & & + \\
\hline 70 & 24 & 21 & 21 & 20 \\
\hline
\end{tabular}

to width. When describing the angle of origin of tertiary veins, we use $A, R$, and $O$ to represent acute, right, and obtuse angles respectively (Dilcher, 1974). For example, AO represents tertiary veins originated from the exmedial (lower or proximal) side of the secondary veins at acute angles $(A)$ and at obtuse angles $(\mathrm{O})$ from the admedial (upper or distal) side of the secondary veins.

We only provide diagnoses for newly established taxa in this report. For new occurrences of previously published taxa we only provide descriptions. Table 1 is a list of taxa reported from the Braun (Wang and Dilcher, 2006a) and Hoisington 
III localities, Kansas (this paper), Courtland I locality, Minnesota (Wang and Dilcher, 2009), and Rose Creek locality, Nebraska (Upchurch and Dilcher, 1990).

\section{SYSTEMATIC PALEOBOTANY}

\section{Family cf. CHLORANTHACEAE R. Br. ex Sims, 1820}

Genus CRASSIDENTICULUM Upchurch and

Dilcher, 1990

Type species. Crassidenticulum decurrens (Lesquereux) Upchurch and Dilcher, 1990

Crassidenticulum decurrens (Lesquereux) Upchurch and Dilcher, 1990

Figure 4.1

*1892 Celastrophyllum decurrens Lesquereux, p. 172, plate 36, figure 1.

Description. Leaflet margin toothed. Primary venation pinnate; primary vein massive, course straight. Secondary venation mixed craspedodromous (most of the secondary veins terminating at the margin and the rest brochidodromous); secondary veins thin, angle of divergence wide acute at $80^{\circ}$; course of secondary veins irregular, straight, slightly curved or recurved; secondary veins densely arranged, 5 to 10 pairs per $\mathrm{cm}$ at middle portion of lamina, spacing irregular; intersecondary veins common. Veins of higher order not observed.

Number of specimens examined. 2 .

Specimens illustrated. UF15706-24648 (Figure 4.1).

Occurrences. Rose Creek locality, Nebraska; Braun Ranch and Hoisington III localities, Kansas.

Remarks. The venation pattern and tooth type of the two leaflet fragments are consistent with those described by Upchurch and Dilcher (1990) and Wang and Dilcher (2006a). Therefore, we interpret this specimen as conspecific and the blade as a leaflet. The chloranthoid tooth type (tooth with a prominent, often thickened gland, a medial vein and a pair of accessory veins that run along the tooth margin and fuse with the gland) and the secondary venation pattern of Crassidenticulum show its closest similarities with extant Chloranthaceae (Upchurch and Dilcher 1990).

\section{Crassidenticulum trilobum Dilcher and Wang,} 2006a

Figure 4.2

Description. Leaf trilobate. Petiole up to $6.5 \mathrm{~cm}$ long and $1 \mathrm{~mm}$ wide. Sinus between lobes more than $80 \%$ of lamina length, structurally reinforced by lamina tissue. Margin toothed with angular sinus; five to ten serrations per $\mathrm{cm}$ with axes inclined to the tangent of the leaf margin; apical angle of tooth acute. Primary venation actinodromous; primary veins massive with straight course. Middle lobe base symmetrical whereas lateral lobe bases strongly asymmetrical. Secondary veins thin; angle of divergence moderate to wide acute; course of secondary veins uniformly curved before joining exmedial branches of superadjacent secondary vein forming intercostal regions irregular in shape and size; intersecondary veins common. Veins of secondary order or higher poorly preserved.

Number of specimens examined. 1. Specimens illustrated. UF15706-24677 (Figure 4.2).

Occurrences. Braun Ranch and Hoisington III localities, Kansas.

Remarks. This species is common in the Braun Ranch locality, Kansas (Wang and Dilcher, 2006a). Though only one specimen is observed from the Hoisington III locality, a suite of characters, including trilobate leaf, massive multi-stranded primary vein, secondary venation pattern, and its chloranthoid tooth type are consistent with those described by Wang and Dilcher (2006a).

\section{cf. Crassidenticulum trilobum Dilcher and Wang, $2006 a$}

Figure 4.3-4

Description. Leaf simple, five-lobed; lobe shape lanceolate; medial lobe base symmetrical while lateral lobe base strongly asymmetrical; margin of lobes toothed except on the extreme base of lamina; axes of serrations inclined to the tangent of the margin, apical angle acute; serration type convex (basal side)-convex (apical side); sinus of tooth rounded; eight to 10 teeth per $\mathrm{cm}$, regularly spaced; teeth simple (all of one size); sinus between lobes rounded, bracing accomplished by primary veins (lamina structure lacking or less than $0.5 \mathrm{~mm}$ wide on the sinus). Petiole thin; observed petiole $5 \mathrm{~cm}$ long and $0.5 \mathrm{~mm}$ wide. Secondary venation of lamina lobes pinnate; secondary veins thin. Veins of higher order not observed.

Number of specimens examined. 1.

Specimens illustrated. UF15706-24684 (Figure 4.3-4).

Occurrences. Hoisington III locality, Kansas.

Remarks. The single specimen examined lacks the details of higher order venation pattern. The five-lobed leaf appears to be compound, but there is lamina tissue connecting adjacent lobes (Figure 4.4). The secondary venation pattern of the lamina 

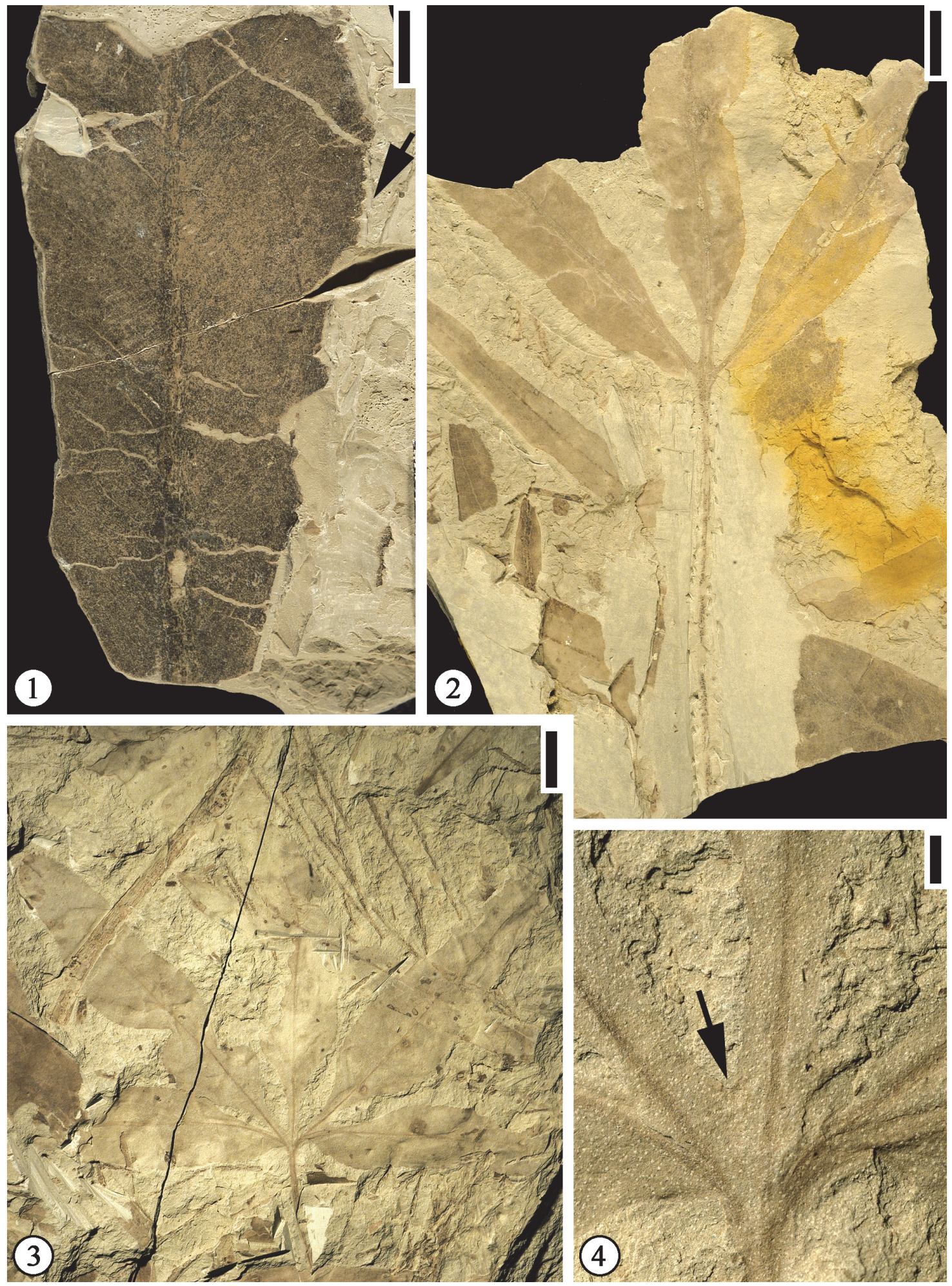

FIGURE 4. 1, Crassidenticulum decurrens (Lesquereux) Upchurch and Dilcher, 1990, UF15706-24648, fragment of leaf lamina. Note fine teeth on margin (indicated by arrow). Scale bar equals $2 \mathrm{~mm}$. 2, Crassidenticulum trilobum Dilcher and Wang, 2006a, UF15706-24677, a trilobed leaf. Note thin and long petiole. Scale bar equals $1 \mathrm{~cm} .3-4$, cf. Crassidenticulum trilobum Dilcher and Wang, 2006a, UF15706-24684, a five lobed leaf (scale bar equals $1 \mathrm{~cm})(3)$ and an enlargement of Figure 4.3 to show decurrent lamina tissue between two adjacent lobes (indicated by arrow) (scale bar equals $1 \mathrm{~mm})(\mathbf{4})$. 
lobes and the tooth type on the margin are similar to those of Crassidenticulum trilobum Dilcher and Wang (2006a). It is possible that this species is a variant of $C$. trilobum.

This species differs from those compound leaves with several petiolulate leaflets from the mid-Cretaceous Cedar Mountain Formation, Utah, i.e., Morphotype CM15 (Harris and Arens, 2016, p. 654-655, figure 7.1-4) and Europe, i.e., Debeya insignis (Hosius and von der Marck) Knobloch from southern Poland and western Ukraine (Halamski, 2013) and Austria (Herman and Kvaček, 2007a, 2007b, 2010), in that the leaf from the Hoisington III locality is simple with five lobes connected at the base with lamina tissue.

Family cf. NYMPHAEACEAE Salisbury, 1805 (including CABOMBACEAE A. Richard ex A. Richard, 1822)

Genus AQUATIFOLIA Wang and Dilcher, 2006b

Type species. Aquatifolia fluitans Wang and Dilcher, 2006b

\section{Aquatifolia fluitans Wang and Dilcher, 2006b Figure 5.1-2}

Description. Leaf shape wide ovate (length/width ratio $1.2: 1$ ) to very wide ovate (L/W ratio $1: 1$ or less). Leaf base strongly cordate, with basal lobes overlapping or wide obtuse. Observed petiole length $28 \mathrm{~mm}$ long and $1.5 \mathrm{~mm}$ wide, containing a spherical float at a distance of ca. $10 \mathrm{~mm}$ from the leaf base (measured from the center of the spherical float to the leaf base). Float present on the petiole, spherical, sometimes appearing to be bilobed, or fusiform with some fine reticulate venation. Leaf margin entire, crenate, or strongly crenate. Typically, three veins entering a tooth with one medial vein perpendicular to the leaf margin and two flanking lateral veins (tertiary or quaternary) running along the margin before joining the medial vein. Primary venation is actinodromous or basal actinodromous; course of primary veins sinuous or straight; typically, one medial and four lateral primary veins (in two pairs) present in one leaf lamina. Primary veins and lateral secondary veins may fork up to three to four times, and adjacent branches join to form five - to six - sided elongate meshes oriented perpendicular to the leaf margin. All lateral primary veins and exmedial branches of lateral primary veins apically curved. Veins of higher order (tertiary or quaternary) orthogonally reticulate, forming quadrangular or pentagonal small meshes within those meshes formed by primary and secondary veins. Near the leaf margin, the veins dichotomize into veins of tertiary or qua- ternary order to form anastomosing loops from which arise one medial and two lateral veins that enter the tooth. Quinternary veins also orthogonally reticulate, forming the smallest polygonal meshes.

Number of specimens examined. 75.

Specimens illustrated. UF15706-8263, 8263' (Figure 5.1); 24120 (Figure 5.2).

Occurrences. Hoisington III locality, Kansas.

Remarks. Two specimens from Wang and Dilcher (2006b) are illustrated in this report. Figure 5.1 is the holotype specimen of Aquatifolia fluitans, showing the spherical float on the petiole. Figure 5.2 is a paratype specimen showing actinodromous primary venation and ovate leaf shape.

Genus BRASENITES Wang and Dilcher, 2006b

Type species. Brasenites kansense Wang and Dilcher, 2006b

\section{Brasenites kansense Wang and Dilcher, 2006b}

Figure 5.3-4

Description. Leaf margin entire; shape suborbiculate $(\mathrm{L} / \mathrm{W}$ ratio $1.2: 1)$ to orbiculate (L/W ratio $1: 1)$; lamina slightly funnel form at the position where the petiole is attached; leaf base peltate central (petiole attached within the boundaries of the leaf margin and near the center of the leaf). Primary venation actinodromous, consisting of 11 primary veins in one leaf lamina; five major primary veins present, with three of them directed oppositely (apically directed) from the other two; three minor primary veins radiate from the leaf center toward each lateral side; central major primary vein of the three extending nearly to the leaf margin, producing pinnate secondary veins; two apically directed and the two basally directed primary veins having strong exmedial branches, which fork repeatedly. Secondary veins produced from forked primary veins join adjacent branches to form polygonal (five- to six-sided) meshes both variable in shape and size, intergrading with higher-order (tertiary or quaternary) veins at a fourth to a third of the distance of the radius near the margin. Numerous small rounded protuberances present on the entire lamina.

Number of specimens examined. 4.

Specimens illustrated. UF15706-14806 (Figure 5.3-4).

Occurrences. Hoisington III locality, Kansas.

Remarks. One specimen (Figure 5.3) and its line drawing (Figure 5.4) are presented in this report. Figures 5.3 and 5.4 show the typically suborbiculate leaf shape, entire leaf margin, centrally peltate base, and major primary veins of this species. Similar leaves have also been reported from the early 



FIGURE 5. 1-2, Aquatifolia fluitans Wang and Dilcher 2006b, UF15706-8263', leaf showing the spherical float on the petiole (1) and UF15706-24120, leaf showing cordate base and thin high order venation (2). Scale bars equal $5 \mathrm{~mm}$. 3-4, Brasenites kansense Wang and Dilcher, 2006b, UF15706-14806, specimen (3) and line drawing (4) to show suborbiculate leaf shape, entire leaf margin, peltate central base, major primary veins. Scale bars equal $1 \mathrm{~cm}$. 
Campanian Grünbach flora from the Grünbach Formation of the Grünbach-Neue Welt Basin, Austria (Herman and Kvaček, 2007a, 2007b), and the Late Cretaceous Arman Formation Northeastern Russia (Herman et al., 2016). Brasenites kansense differs from Exnelumbites callejasiae, a fossil taxon described from the Late Cretaceous McRae Formation, Mexico, in having much stronger bilateral symmetry to the venation, an entire margin, and suborbicular lamina (Estrada-Ruiz et al., 2011). For differences among Brasenites, Exnelumbites and other fossil members of the Nelumbonaceae, and other aquatic plants, see EstradaRuiz et al. (2011, table 1).

A phylogenetic analysis that includes three Early Cretaceous fossil species (including Brasenites kansense) with peltate leaves (Taylor et al., 2008) indicates their affinities to Cabombaceae. However, in a recent analysis by Taylor and Gee (2014), adding the fossil leaves of Brasenites kansense (Wang and Dilcher, 2006b), Pluricarpellatia peltata (Mohr et al., 2008) and Scutifolium jordanicum (Taylor et al., 2008) results in the loss of many of the monophyletic groups found in the living-taxa analysis.

cf. Family SCHISANDRACEAE Blume, 1830

(including ILLICIACEAE A.C. Smith, 1947)

Genus LONGSTRETHIA Upchurch and Dilcher, 1990

Type species. Longstrethia varidentata Upchurch and Dilcher, 1990

Longstrethia aspera (Lesquereux) comb. nov. Figure 6

*1892 "Myrica" aspera Lesquereux, p. 66, pl. 2, fig. 11.

Emended specific diagnosis. Lamina margin toothed; serrate axes inclined to the tangent of margin, serration type straight or convex-straight or convex; tooth simple, spacing irregular; sinus rounded; three veins entering each tooth with one medial secondary vein or branch from secondary vein, two accompanying veins from basal and apical side, these two veins joining superadjacent veins of the same order to form loops before entering tooth. Primary venation pinnate; primary vein stout, multi-stranded, course curved. Secondary venation mixed craspedodromous (most of the secondary veins terminating at the margin and the rest brochidodromous); secondary veins thin relative to primary vein, subopposite; originating from primary vein at moderate acute angles, uniformly apically curved before entering the tooth or running along the basal side of tooth before terminating on the tooth with superadjacent secondary veins. Intersecondary veins present, composite. Tertiary veins thin, orthogonal reticulate, forming irregular meshes. Quaternary vein orthogonal reticulate, forming imperfect areoles. Veinlets simple, linear or curved.

Description. Observed lamina $9 \mathrm{~cm}$ to $15 \mathrm{~cm}$ long and $1.5 \mathrm{~cm}$ to $2.5 \mathrm{~cm}$ wide. Margin toothed; serrate axes inclined to the tangent of margin, serration type straight or convex-straight or convex; tooth simple, spacing irregular, one per $\mathrm{cm}$; extending on all margin observed; sinus rounded, up to $1.5 \mathrm{~mm}$ deep (vertical distance from adjacent tooth apex to bottom of sinus); three veins entering each tooth with one medial secondary vein or branch from secondary vein, two accompanying veins from basal and apical side, these two veins joining superadjacent veins of same order to form loops before entering tooth. Primary venation pinnate; primary vein stout, multi-stranded, course curved. Secondary venation mixed craspedodromous (most of the secondary veins terminating at the margin and the rest brochidodromous); secondary veins thin relative to primary vein, one pair per $\mathrm{cm}$, subopposite; originating from primary vein at moderate acute angles, uniformly apically curved before entering the tooth or running along the basal side of tooth before terminating on the tooth with superadjacent secondary veins. Intersecondary veins present, composite. Tertiary veins thin, orthogonal reticulate, forming meshes irregular in shape and size. Quaternary vein orthogonal reticulate, forming imperfect areoles. Veinlets simple, linear or curved.

Number of specimens examined. 2.

Lectotype. Longstrethia aspera Lesquereux (1892, p. 66, plate 2, figure 11; designated here).

Paratypes. UF15706-24578 (Figure 6.1, 6.3); 24650 (Figure 6.2).

Occurrences. Hoisington III locality, Kansas.

Remarks. Two specimens with middle portion of lamina are examined. Lesquereux (1892, p. 66, plate 2, figure 11) reported two specimens from the Pipe Creek locality, Cloud County, Kansas and assigned them to the extant genus Myrica. However, leaf architecture and cuticular characters of these leaves show a possible relationship to Illiciales or Trimerniaceae but differ from all extant members of the Magnoliidae in at least several characters (Upchurch and Dilcher, 1990, p. 33-34). We assign these specimens to the fossil genus Longstrethia established by Upchurch and Dilcher (1990) and set up a new combination for the specimens from the Hoisington III locality, Kansas. 

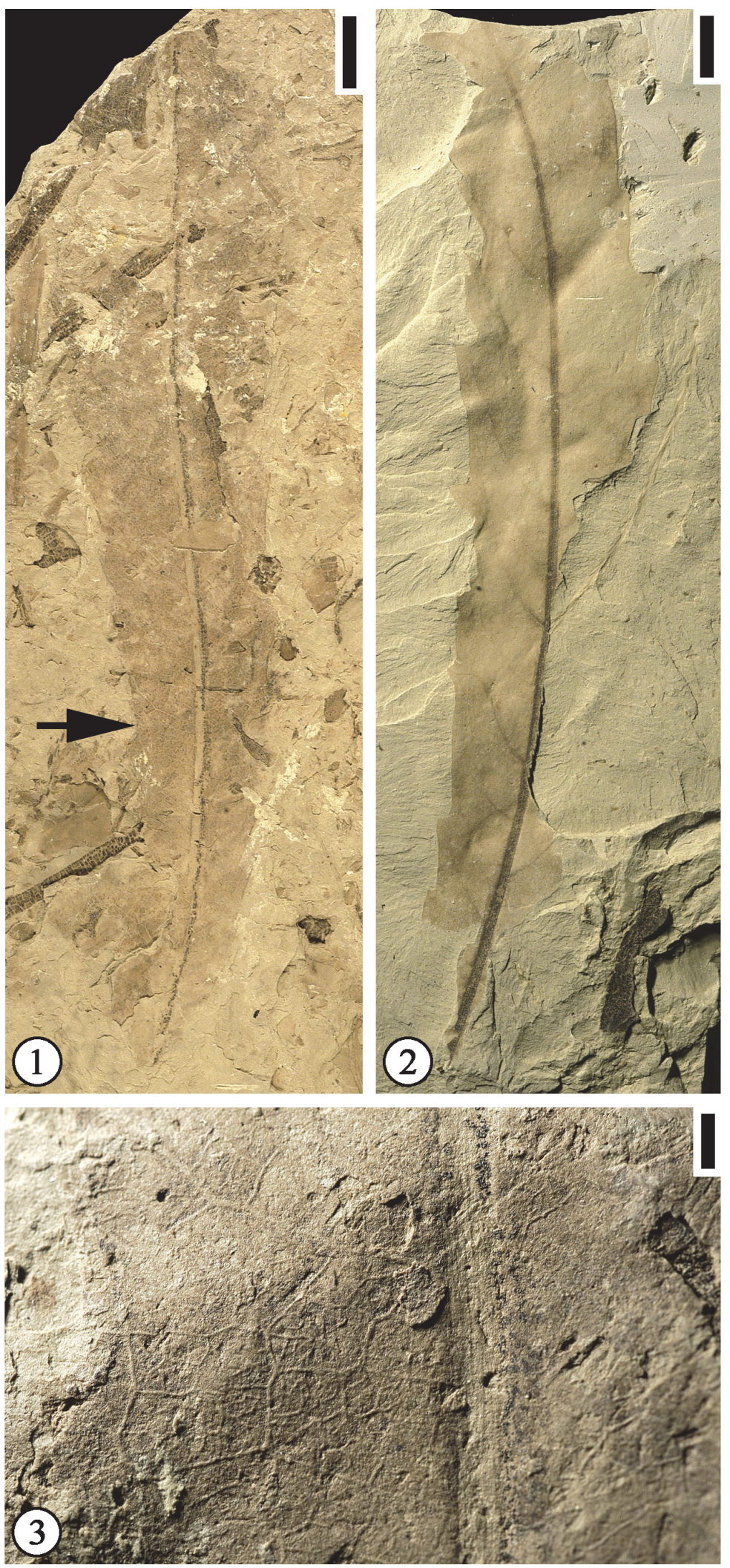

FIGURE 6. Longstrethia aspera (Lesquereux) comb. nov. 1, UF15706-24578, middle and lower portion of lamina. Scale bar equals $1 \mathrm{~cm}$. 2, UF15706-24560, specimen showing secondary veins and toothed margin. Scale bar equals $5 \mathrm{~mm}$. 3, Enlargement of Figure 6.1 (left middle portion of lamina; indicated by arrow) to show fine venation. Scale bar equals $2 \mathrm{~mm}$. 
Longstrethia aspera is similar to Longstrethia varidentata Upchurch and Dilcher in that both have linear leaf shape and toothed margin, but they differ in that (1) leaf margin of Longstrethia varidentata varies from entire to coarsely toothed, (2) secondary venation varies from brochidodromous with strongly flattened brochidodromous loops, to pinnate with an intramarginal vein, and (3) relatively thin and numerous secondary veins. Future collection of specimens with well-preserved cuticle from the Hoisington III locality may provide information to clarify the relationship between the specimens from the Hoisington III locality, Kansas and those from the Rose Creek locality, Nebraska described by Upchurch and Dilcher (1990).

\section{Clade MAGNOLIIDS Angiosperm Phylogeny Group, 2009 \\ Order LAURALES Perleb, 1826 \\ Genus PABIANIA Upchurch and Dilcher, 1990}

Type species. Pabiania variloba Upchurch and Dilcher, 1990

Pabiania variloba Upchurch and Dilcher, 1990 Figures 7-8

v. 1981a Acerites multiformis Lesquereux; Retallack and Dilcher, 1981a, p. 38, fig. 2.4.

Description. Leaf commonly trilobate, rarely bilobate or unlobed; base ranging from acute to obtuse and tending towards cuneate, with the basalmost portion of the lamina decurrent on the petiole; margin entire; apex of lobes acute to rounded; unlobed leaves broad elliptic to obovate, with rounded apex. Primary venation basal to suprabasal actinodromous in 3-lobed leaves, pinnate in unlobed leaves; midvein moderate; lateral primary veins similar to midvein in thickness, at lower angle than superadjacent secondary veins and tending to be recurved, commonly decurrent on midvein, producing one to three festooned brochidodromous external branches. Secondary venation festooned brochidodromous; secondary veins thin or moderate relative to primary veins, three to six pairs along midvein, with one pair of basilaminar secondary veins present in all leaves, alternate, moderate acute, straight to apically curved, tending to be festooned brochidodromous except near sinuses. Tertiary venation reticulate; tertiary veins thin relative to secondary veins, opposite to alternate, closely but somewhat irregularly spaced, originating at acute to right angles. Quaternary venation intergrading with tertiary veins, generally unbranched; quaternary veins opposite to alternate, non-orthogonal, enclosing somewhat elongate, 4-sided regions. Quinternary venation highly irregular, both ramified and reticulate, arising both from thick lateral branches of the quaternary veins and from the sides of lower order veins; quinternary veins weak, curved, often producing branches to form an open venation. Areolation poorly developed. Marginal venation consisting of a thin fimbrial vein

Number of specimens examined. 90.

Specimens illustrated. UF15706-24423 (Figure 7.1-3); 30154 (Figure 7.4-5); 14832 (Figure 7.6); 14823 (Figure 8.1); 24464 (Figure 8.2, 8.4); 24587 (Figure 8.3).

Occurrences. Rose Creek locality, Nebraska and Hoisington III locality, Kansas.

Remarks. In Upchurch and Dilcher's (1990) diagnosis and description of this species, the primary venation was described as palinactinodromous. Observations based on Hoisington III locality specimens indicate that the primary venation of $P$. variloba can vary from basal actinodromous (Figure 8.1), suprabasal actinodromous (Figure 7.6), to suprabasal palinactinodromous (Figure 7.1-3). The leaves from the Rose Creek locality, Nebraska described by Upchurch and Dilcher (1990) and stored at the Paleobotany collection in the Florida Museum of Natural History (more than 100 specimens) are smaller in size compared with the specimens from the Hoisington III locality, Kansas. The specimens from the Hoisington III locality also show that the petioles are long and they have winged lamina tissue along both sides. The petiole base may be ocreate (Figure 7.4, 7.5). Other variations of leaf morphological characters include: (1) lamina from unlobed (Figure 8.3) to trilobed (Figures 7.1, 7.6, 8.1-2); leaf base from acute (Figure $7.6)$ to rounded (Figure 8.1); (2) apex of lamina lobes from acute (Figure 7.6), rounded (Figure 7.1 ), to mucronate (Figure 8.2). All other leaf morphological characters are consistent with those described by Upchurch and Dilcher (1990).

Heer (1883, plate 38 , figure 3 ) and Lesquereux (1892, plate 54, figures 1-3) described a few specimens with similar leaf morphology and assigned them to Aralia grœnlandica Heer. Unfortunately, only primary and secondary venation are observed on these leaves, which makes it difficult to compare them with the specimens from the Rose Creek and Hoisington III localities.

\section{cf. Family LAURACEAE de Jussieu, 1789 Genus ROGERSIA Fontaine, 1889}

Type species. Rogersia longifolia Fontaine, 1889

Rogersia dakotensis Wang and Dilcher, 2009 Figures 9.1, 9.3, 10.1 

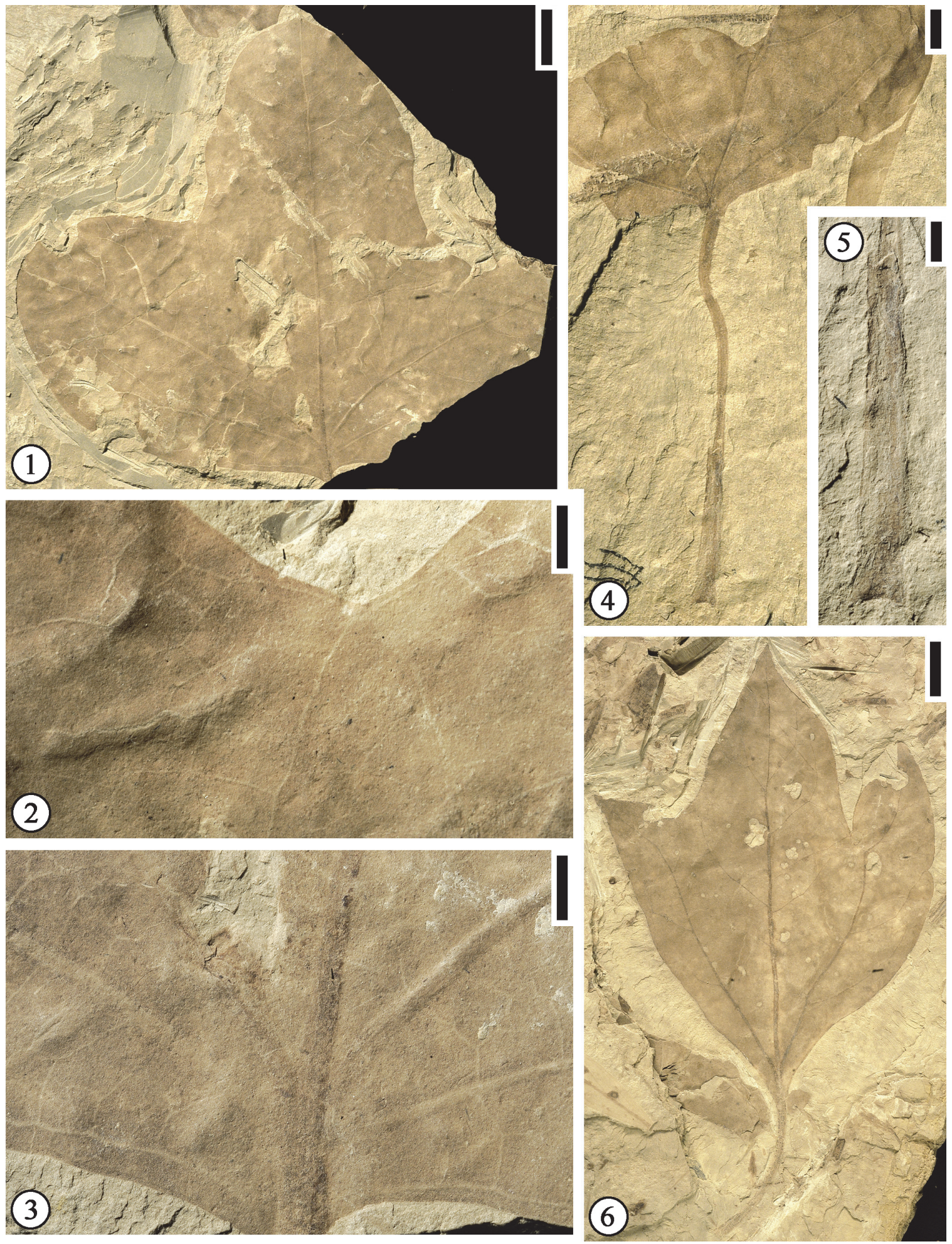

FIGURE 7. Pabiania variloba Upchurch and Dilcher, 1990. 1-3, UF15706-24423, specimen showing suprabasal actinodromous primary venation (scale bar equals $1 \mathrm{~cm})(1)$, enlargement of a sinus area to show sinus bracing by secondary veins (scale bar equals $2 \mathrm{~mm}$ ) (2); and enlargement of basal portion of leaf to show two pairs of basal secondary veins (scale bar equals $2 \mathrm{~mm}$ ) (3). 4-5, UF15706-30154, specimen showing a long petiole and ocrea-like structure at the base (scale bar equals $5 \mathrm{~mm}$ ) (4) and enlargement of the petiole to show the ocrea-like structure (scale bar equals $2 \mathrm{~mm}$ ) (5). 6, UF15706-14832, specimen showing suprabasal actinodromous primary venation and acute apices of the lobes. Scale bar equals $1 \mathrm{~cm}$. 


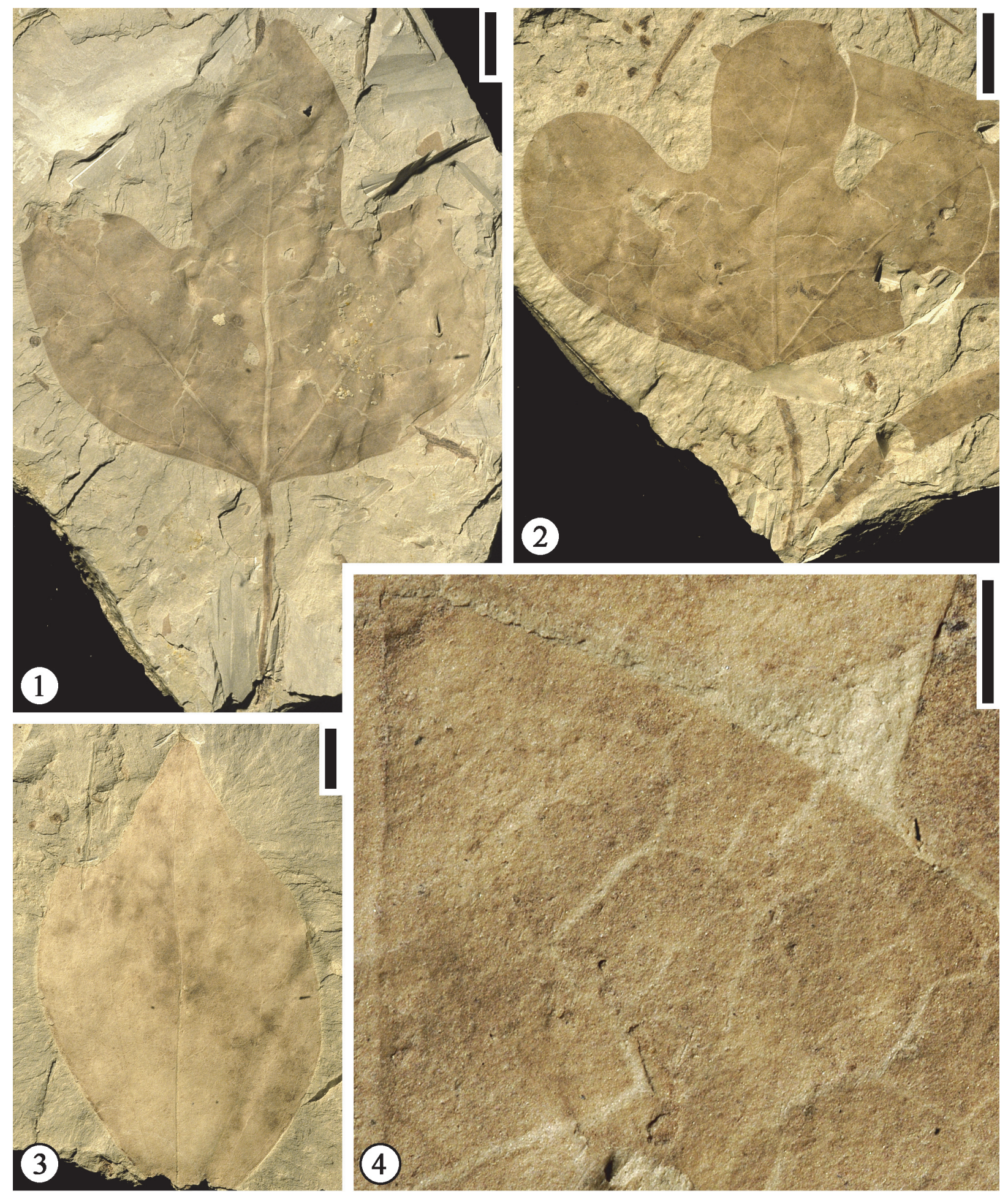

FIGURE 8. Pabiania variloba Upchurch and Dilcher, 1990. 1, UF15706-14823, leaf showing basal actinodromous primary venation and basal secondary veins. Scale bar equals $1 \mathrm{~cm}$. 2, UF15706-24464, leaf showing rounded lobe apex. Scale bar equals $1 \mathrm{~cm}$. 3, UF15706-24587, specimen showing a small lobe on the left and entire margin on the right of the leaf. Scale bar equals $5 \mathrm{~mm}$. 4, Enlargement of Figure 8.2 to show straight primary vein extending to lobe apex and two series of loops in the excostal region. Scale bar equals $1 \mathrm{~mm}$. 

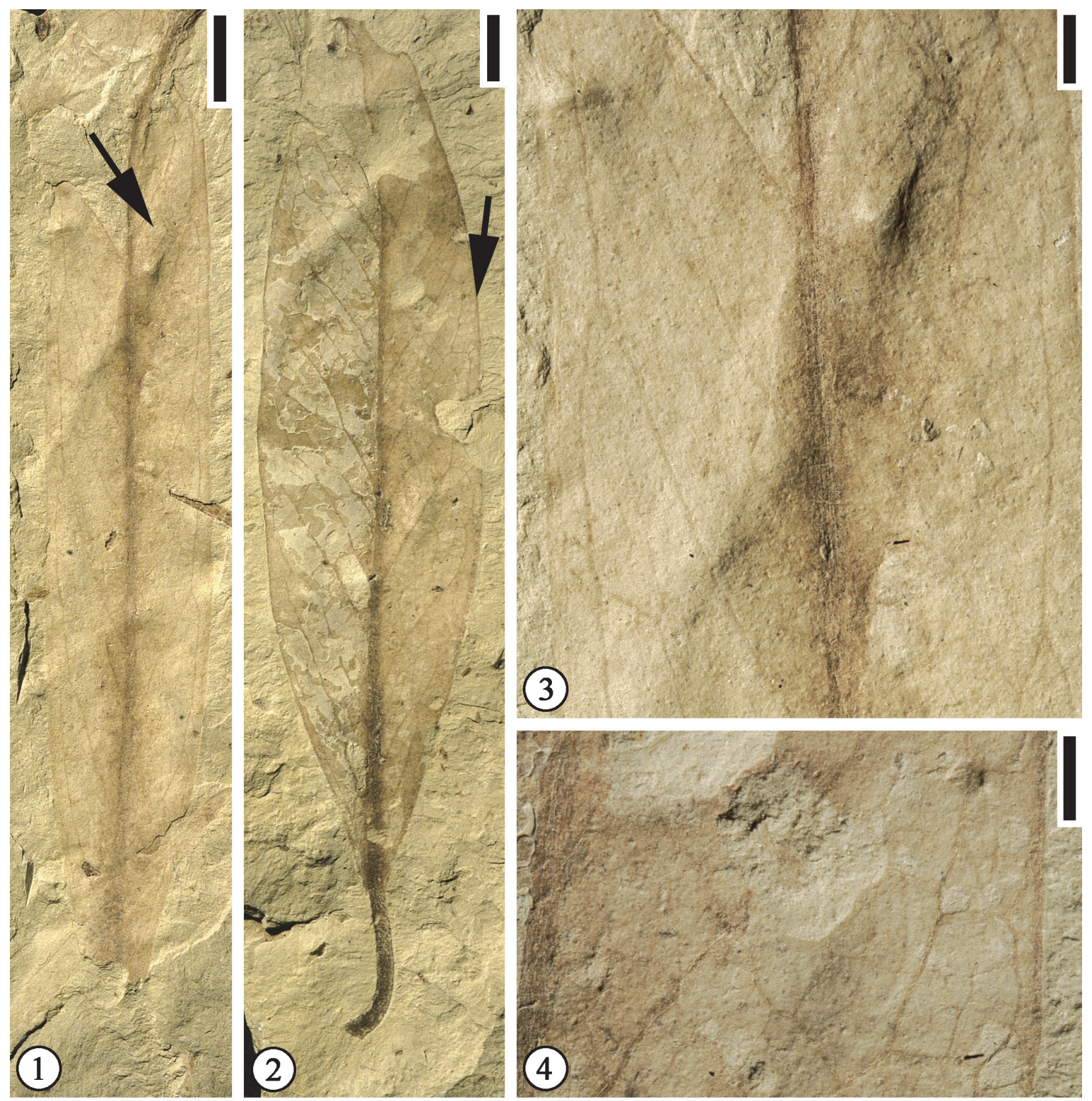

FIGURE 9. 1 and 3, Rogersia dakotensis Wang and Dilcher, 2009, UF15706-24798, general leaf shape, note thin secondary veins forming intramarginal veins (scale bar equals $5 \mathrm{~mm}$ ) (1) and enlargement to show intramarginal veins formed by looping secondary veins (scale bar equals $1 \mathrm{~mm}$ ) (3). 2 and 4, Rogersia parlatorii Dilcher and Wang, 2006, UF15706-7529, specimen showing leaf shape (scale bar equals $5 \mathrm{~mm}$ ) (2) and enlargement to show secondary venation (scale bar equals $5 \mathrm{~mm}$ ) (4).

Description. Leaf simple; whole lamina and base symmetrical; form linear oblong, L/W >9, $7.5 \mathrm{~cm}$ to $9 \mathrm{~cm}$ long and $0.5 \mathrm{~cm}$ to $1 \mathrm{~cm}$ wide. Apex attenuate. Base acute, decurrent. Margin entire. Petiole short, stout. Primary venation pinnate; primary vein stout, multi-stranded; course straight or slightly curved. Secondary venation brochidodromous; secondary veins thin relative to primary vein; subopposite, decurrent on primary vein; angle of divergence narrow acute (ca. $30^{\circ}$ ), spacing irregular; secondary veins uniformly curved to join exmedial branches of superadjacent secondary veins or superadjacent secondary veins at a distance of one fifth to one fourth of half lamina to form an 

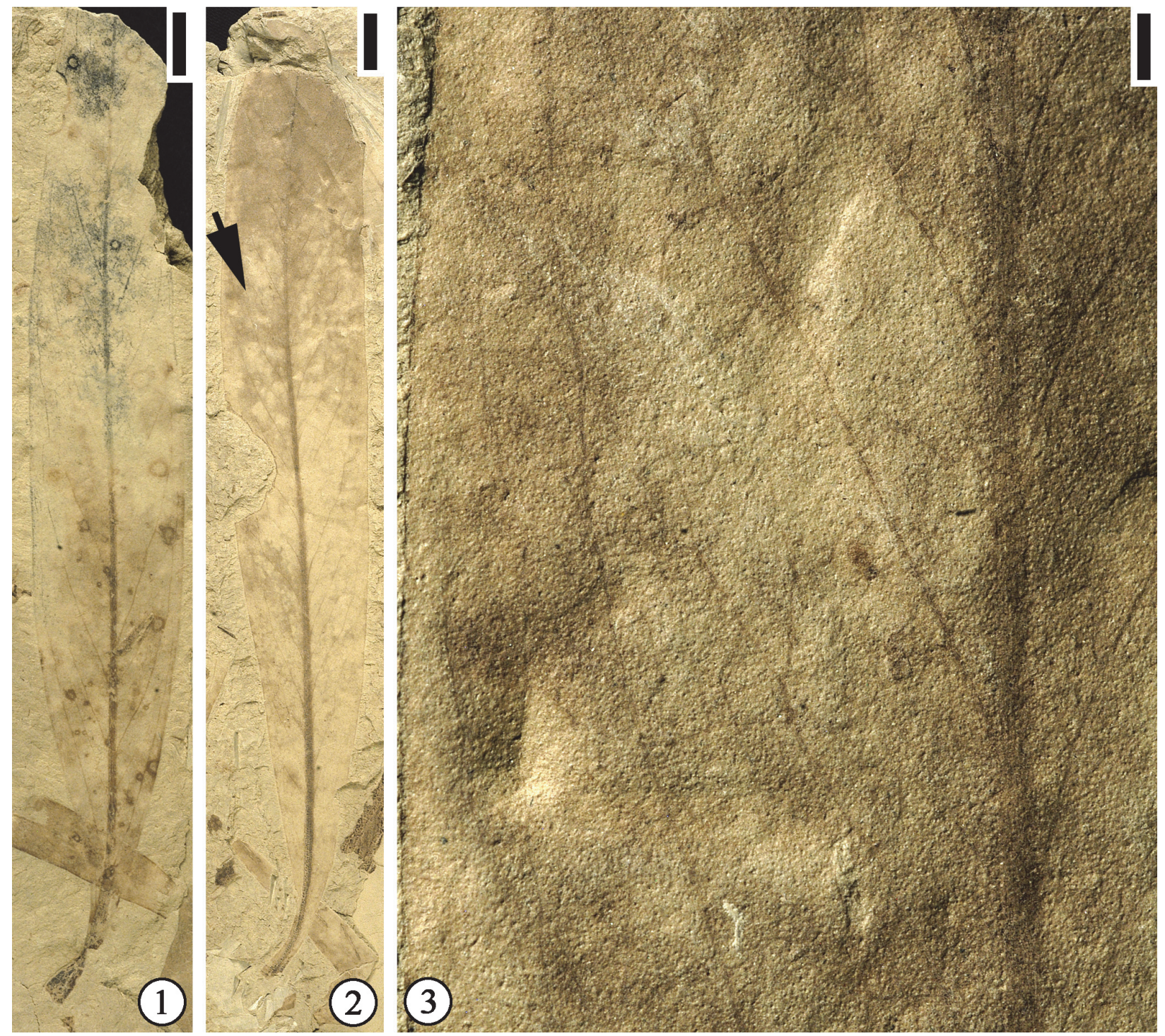

FIGURE 10. 1, Rogersia dakotensis Wang and Dilcher, 2009, UF15706-24620, general leaf shape. Note short petiole. Scale bar equals $5 \mathrm{~mm}$. 2-3, Wolfiophyllum pfaffianum (Heer) Wang and Dilcher, 2009, UF15706-14815, basal and middle portion of leaf, note strong primary vein and entire margin (scale bar equals $1 \mathrm{~cm})(2)$ and enlargement of Figure 10.2 (area indicated by arrow) to show eucamptodromous venation, note intersecondary veins (Scale bar equals $1 \mathrm{~mm})(3)$.

intercostal region with its long axis oblique primary vein $\left(\right.$ ca. $\left.30^{\circ}\right)$, then continuing to join exmedial branches of adjacent secondary veins to form two series of loops; these loops enclosing elongate areas with long axis almost parallel to leaf margin; secondary veins running along the margin appearing to be intramarginal veins. Intersecondary veins present, one per intercostal region, simple, extending about one half of the distance from primary vein to leaf margin and then intersect with superadjacent secondary veins. Tertiary veins thin, irregular, percurrent with retroflexed or straight course. Veins of higher order not observed.

Number of specimens examined. 200.

Occurrences. Hoisington III locality, Kansas and Courtland I locality, Minnesota.

Specimens illustrated. UF15706-24798 (Figure 9.1, 9.3); UF15706-24620 (Figure 10.1).

Remarks. Rogersia dakotensis is similar in leaf shape and angle of divergence of secondary veins to Wolfiophyllum heigii from the Braun's Ranch locality of Kansas, but they differ in that $W$. heigii has eucamptodromous secondary venation, fork- 
TABLE 2. Comparisons of leaf shape and venation of Rogersia and Wolfiophyllum species (modified from table 1 of Wang and Dilcher, 2009).

\begin{tabular}{|c|c|c|c|c|c|c|c|}
\hline Taxon & Leaf shape & $2^{\circ}$ venation & $\begin{array}{c}\text { Number of } 2^{\circ} \\
\text { veins }\end{array}$ & $\begin{array}{l}\text { Loops near } \\
\text { margin }\end{array}$ & $\begin{array}{l}\text { Intercostal } \\
\text { region }\end{array}$ & $\begin{array}{l}\text { Intersecondary } \\
\text { veins }\end{array}$ & $\begin{array}{l}\text { Tertiary } \\
\text { veins }\end{array}$ \\
\hline $\begin{array}{l}\text { Wolfiophyllum } \\
\text { pfaffianum }\end{array}$ & $\begin{array}{l}\text { very narrow } \\
\text { elliptic }\end{array}$ & eucamptodromous & 8 & no & no & common & reticulate \\
\hline $\begin{array}{l}\text { Wolfiophyllum } \\
\text { heigii }\end{array}$ & lorate or linear & eucamptodromous & 10 to 12 & no & no & present & $\begin{array}{l}\text { percurrent or } \\
\text { exmedially } \\
\text { ramified }\end{array}$ \\
\hline $\begin{array}{l}\text { Wolfiophyllum } \\
\text { daphneoides }\end{array}$ & $\begin{array}{l}\text { narrow ovate to } \\
\text { lanceolate }\end{array}$ & eucamptodromous & 5 to 7 & no & no & common, simple & Not observed \\
\hline $\begin{array}{l}\text { Rogersia } \\
\text { dakotensis }\end{array}$ & linear oblong & brochidodromous & $>10$ & $\begin{array}{l}\text { two series, } \\
\text { elongate area }\end{array}$ & well defined & present & $\begin{array}{l}\text { percurrent, } \\
\text { more or less } \\
\text { irregular }\end{array}$ \\
\hline Rogersia lottii & narrow elliptic & $\begin{array}{l}\text { festooned } \\
\text { brochidodromous }\end{array}$ & 10 & one series & well defined & present, simple & $\begin{array}{l}\text { random } \\
\text { reticulate }\end{array}$ \\
\hline $\begin{array}{l}\text { Rogersia } \\
\text { parlatorii }\end{array}$ & $\begin{array}{l}\text { oblong, lorate to } \\
\text { linear }\end{array}$ & brochidodromous & $>10$ & irregular & $\begin{array}{l}\text { elongate and } \\
\text { admedially } \\
\text { oriented }\end{array}$ & common & $\begin{array}{l}\text { intergrading } \\
\text { with } 2^{\circ} \text { and } 4^{\circ}\end{array}$ \\
\hline
\end{tabular}

ing secondary veins near margin, and percurrent or exmedially ramified tertiary veins (Table 2).

Rogersia parlatorii Wang and Dilcher, 2006a

Figure 9.2, 9.4

Description. Leaf simple; whole lamina and base symmetrical; form narrow elliptic, $7.5 \mathrm{~cm}$ long and $1.8 \mathrm{~cm}$ wide. Apex probably attenuate. Base acute, decurrent. Margin entire. Petiole normal, $1.1 \mathrm{~cm}$ long and $1 \mathrm{~mm}$ wide. Primary venation pinnate; primary vein stout, multi-stranded, course straight. Secondary venation festooned brochidodromous; ca. 10 pairs per lamina, opposite or subopposite, decurrent; angle of divergence narrow acute (ca. $30^{\circ}$ ), with lowest two or three pairs more acute than pairs above; spacing of secondary veins irregular, course uniformly curved; secondary veins joining exmedial branches of superadjacent secondary veins to form two series of loops. Intersecondary veins present, simple. Tertiary veins thin, predominately percurrent; angle of origin $\mathrm{AO}$ (acute on the lower side of the secondary and obtuse on the upper side), primary vein-tertiary vein angle oblique; course slightly wavy. Quaternary veins thin, orthogonal reticulate, anastomosing to form pentagonal or quadrangular meshes. Veins of higher order not observed.

Number of specimens examined. 2.

Occurrences. Braun Ranch and Hoisington III localities, Kansas.

Specimens illustrated. UF15706-7529 (Figure 9.2, 9.4).

Remarks. This species is abundant at the Braun Ranch locality, Kansas. See Table 2 for the differ- ences between this species and other Dakota Formation entire margined leaves.

\section{Genus WOLFIOPHYLLUM Dilcher and Wang, 2006}

Type species. Wolfiophyllum heigii Dilcher and Wang, 2006

\section{Wolfiophyllum pfaffianum (Heer) Wang and Dilcher, 2009 \\ Figure 10.2-3}

Description. Leaf simple; whole lamina and base symmetrical; form very narrow elliptic to narrow oblong, L/W 4 to $>7,10 \mathrm{~cm}$ to $12 \mathrm{~cm}$ long (estimated maximum length) and $1.3 \mathrm{~cm}$ to $2.6 \mathrm{~cm}$ wide. Apex missing. Base acute, decurrent. Margin entire. Petiole normal, short, stout, up to $1 \mathrm{~cm}$ long and $1.5 \mathrm{~mm}$ wide, with decurrent lamina tissue on both sides, curved to one side. Primary venation pinnate; primary vein stout, multi-stranded, course straight or slightly curved. Secondary venation eucamptodromous, secondary veins upturned and gradually diminishing apically near the margin, connected to the superadjacent secondary veins by a series of cross veins without forming prominent marginal loops; secondary veins up to 12 pairs per lamina; angle of divergence uniform, narrow acute (less than $45^{\circ}$ ); secondary veins uniformly curved and gradually diminishing apically inside the margin, connected to the superadjacent secondary veins without forming prominent loops; secondary vein course apically curved, occasionally forking near the margin; intersecondary veins common, one per intercostal region, extending half to almost the same distance as adjacent second- 
ary veins; intersecondary veins simple. Tertiary veins predominately percurrent, course straight; angle of origin $\mathrm{AO}$ (acute on lower side of secondary veins and obtuse on upper side of secondary veins), forming cross veins between adjacent secondary and intersecondary veins. Veins of higher order poorly preserved.

Number of specimens examined. 1.

Specimens illustrated. UF15706-14815 (Figure 10.2-3).

Occurrences. Hoisington III locality, Kansas and Courtland I locality, Minnesota.

Remarks. The suite of characters, especially the combination of narrow elliptic simple leaf and eucamptodromous venation is different from any other angiosperm leaf megafossils from the Hoisington III locality, Kansas. The distinction between Wolfiophyllum pfaffianum with other similar leaves from the Dakota Formation is presented in Table 2.

Order MAGNOLIALES Bromhead, 1838 Genus JARZENIA Wang and Dilcher, 2009

Type species. Jarzenia kanbrasota Wang and Dilcher, 2009

Jarzenia kanbrasota Wang and Dilcher, 2009 Figure 11.1

Description. Lamina elliptic, L/W 2.5, 3.5 to $4 \mathrm{~cm}$ wide and 9 to $10 \mathrm{~cm}$ long (estimated length). Apex missing. Base acute, decurrent. Margin entire. Petiole missing. Primary venation pinnate; primary vein stout, multi-stranded, course straight. Secondary venation brochidodromous; secondary vein moderate relative to primary vein. >eight pairs per lamina, opposite to subopposite, decurrent; spacing irregular; angle of divergence narrow acute $\left(<45^{\circ}\right)$, uniformly curved to join exmedial branches of superadjacent secondary veins to form one series of loops. Intersecondary veins present, course simple. Tertiary veins not well preserved.

Number of specimens examined. 2.

Specimens illustrated. UF15706-3171 (Figure 11.1).

Occurrences. Hoisington III locality, Kansas and Courtland I locality, Minnesota.

Remarks. Jarzenia kanbrasota differs from Setterholmia rotundifolia (Lesquereux) Wang and Dilcher, 2009 in that $J$. kanbrasota has oblanceolate or narrow obovate shape, more cuneate leaf base, lowest one or two pairs of secondary veins originating at more acute angles than those above, not well defined intercostal regions, less percurrent tertiary veins, and the absence of glands on leaf lamina and veins. Jarzenia kanbrasota is very common at several localities of the Dakota Formation in Kansas and Nebraska based upon observation of specimens stored in the Paleobotany and Palynology collection at the Florida Museum of Natural History.

\section{Genus LIRIOPHYLLUM Lesquereux, 1878}

Type species. Liriophyllum populoides Lesquereux (designated by Berry 1902)

Liriophyllum kansense Dilcher and Crane, 1984 Figure 11.2

Description. Leaf petiolate, bilobed and deeply divided. Leaf $13.5 \mathrm{~cm}$ long and $16 \mathrm{~cm}$ wide; petiole $13 \mathrm{~cm}$ long and $3 \mathrm{~mm}$ wide. Primary vein stout, 3 $\mathrm{mm}$ wide, extending to the base of the sinus and forking at about $45^{\circ}$ into two prominent veins forming the leaf margin in the lower part of the sinus. Apex of the lobes broadly rounded; leaf base straight. Secondary venation pinnate, camptodromous; secondary veins alternately arranged; angle of divergence of secondary veins gradually decreasing apically; secondary veins branching and gradually becoming thinner close to the margin to form weak, camptodromous loops, typically of tertiary order. Tertiary veins more or less decurrent where they join the secondary veins and the primary vein. Toward the leaf margin, tertiary, quaternary, and quinternary veins forming polygonal areolae.

Number of specimens examined. 30 .

Specimens illustrated. UF15826-3188 (Figure 11.2).

Occurrences. Linnenberger Ranch and Hoisington III localities, Kansas.

Remarks. The primary vein running to the apex and dividing into a pair of prominent veins contiguous with the lamina margin in the sinus is unique in fossil and extant angiosperm leaves. Based upon the evidence of co-occurrence and common presence of distinctive resin-bodies in both the leaves and fruits, Dilcher and Crane (1984) suggested that Liriophyllum kansense leaves and Archaeanthus, multifollicular angiosperm fruiting axes, are from the same plant species. This plant is closely related to Liriophyllum in Magnoliaceae (Romanov and Dilcher, 2013).

Clade EUDICOTS Doyle and Hotton, 1991 Order PROTEALES Jussieu ex von Berchtold and J. Presl, 1820

Family cf. NELUMBONACEAE von Berchtold and J. Presl, 1820

Genus PALEONELUMBO Knowlton, 1930 


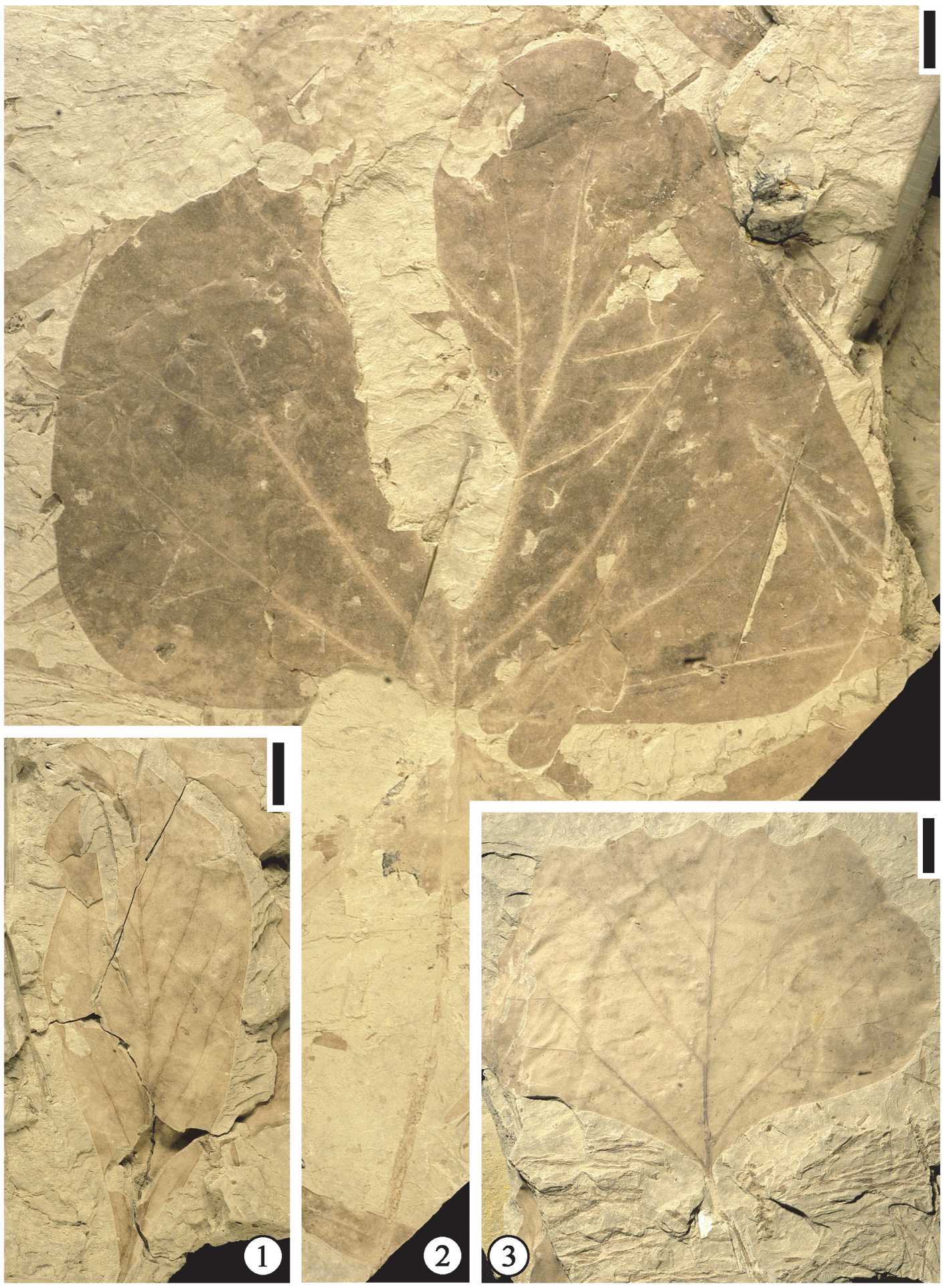

FIGURE 11. 1, Jarzenia kanbrasota Wang and Dilcher, 2009, UF15706-3171, showing elliptic leaf shape and secondary venation. Scale bar equals $1 \mathrm{~cm}$. 2, Liriophyllum kansense Dilcher and Crane, 1984, UF15826-3188, showing deeply lobed leaf, long petiole, and secondary venation. Scale bar equals $1 \mathrm{~cm} .3$, Credneria cyclophylla (Heer) Wang and Dilcher, 2009, UF15706-14821, leaf showing craspedodromous venation. Note all secondary veins and their exmedial branches terminating on leaf margin, resulting in a wavy appearance of leaf margin. Scale bar equals $1 \mathrm{~cm}$. 
Type species. Paleonelumbo macroloba Knowlton, 1930

Paleonelumbo cf. macroloba Knowlton, 1930

Figure 12

Description. Leaf incomplete. Base peltate central; margin lobed with glandular teeth. Primary venation actinodromous with at least eight primary veins extending directly into individual lobes; sinus depth varying from one tenth to one half length of primary vein. Pinnate secondary veins present on the distal portion of lamina, brochidodromous. Tertiary and quaternary veins random reticulate. Vein of higher order not observed.

Number of specimens examined. 1.

Specimens illustrated. UF15826-24649 (Figure 12).

Occurrences. Hoisington III locality, Kansas.

Remarks. One incomplete specimen is observed. This specimen is different from other Cretaceous and Cenozoic species that are assigned to Nelumbonaceae (Saporta, 1894; Berry, 1911d; Knowlton, 1922, 1930; Brown, 1933, 1962; Matsuo, 1954, 1962; Upchurch et al., 1994; Johnson, 2002; Barclay et al., 2003; Gandolfo and Cúneo, 2005; Estrada-Ruiz et al., 2011) in that the specimen from Hoisington III locality is lobed with varying depth of sinus and toothed margin. This specimen resembles Paleonelumbo macroloba Knowlton (Knowlton, 1930, plate 39, figure. 3, plate 42, figures 3, 4; Brown, 1963, plate 35, figure 7; Johnson, 2002; Barclay et al., 2003, figure 9A) and Nelumbo tenuifolia (Lesquereux) Knowlton (Knowlton, 1922, plate 26, figure 7) in having a lobed lamina. They differ in that (1) the Hoisington III specimen has fewer primary veins; (2) it has veins of primary to tertiary order entering the marginal teeth; and (3) it does not possess transverse tertiary veins.

This leaf appears to be sagittate in shape but it only has one pointed lobe. The direction of this lobe is unknown since the leaf is incomplete. The deep sinus (Figure 12.1) does not seem to be the result of insect or mechanical damage since there are consistent looping veins along the margin. We tentatively assign this specimen to Paleonelumbo macroloba because its morphology is more similar to this species than other species assigned to Nelumbonaceae.

Family cf. PLATANACEAE T. Lestiboudois, 1826 Genus CREDNERIA Zenker, 1883

Type species. Credneria denticulata Zenker, 1883
Credneria cyclophylla (Heer) Wang and Dilcher, 2009

Figure 11.3

Description. Whole lamina and base symmetrical, very wide ovate, $L / W<1,8 \mathrm{~cm}$ long (estimated length) and $8.5 \mathrm{~cm}$ wide. Apex missing. Base obtuse, decurrent. Margin toothed; tooth simple, extending on upper two-thirds of the margin, spacing irregular, two or three teeth per $\mathrm{cm}$ on middle portion of margin; dentate axes approximately perpendicular to the tangent of the margin; dentate apex obtuse $\left(>90^{\circ}\right)$, mucronate; toothed type concave on both sides; sinus rounded, shallow (less than $1 \mathrm{~mm}$ deep-vertical distance from tooth apex to bottom of sinus). Observed petiole $3 \mathrm{~cm}$ long and $1 \mathrm{~mm}$ wide. Primary venation pinnate; primary vein stout, multi-stranded, course straight. Secondary venation simple craspedodromous (all of the secondary veins and their branches terminating at the margin); secondary veins thick relative to primary veins, multi-stranded, ca. five pairs per leaf lamina, opposite or subopposite; angle of divergence narrow acute $\left(<45^{\circ}\right)$ with uniform variation; secondary vein course straight or slightly curved, all terminating at the margin; two or three exmedial branches from basal two pairs of secondary veins also terminating on the margin. Intersecondary vein absent. Tertiary veins thick, percurrent, course convex (middle portion of vein curve away from the center of the leaf); angle of origin AA (acute on both sides of secondary veins); arrangement on secondary veins close (interval between veins less than $0.5 \mathrm{~cm}$ ). Quaternary veins percurrent (perpendicular to tertiary veins), course straight; quinternary veins orthogonal reticulate, forming quadrangular well-developed areoles. Veinlets simple, linear or curved.

Number of specimens examined. 3.

Specimen illustrated. UF15706-14821 (Figure 11.3).

Occurrences. Hoisington III locality, Kansas and Courtland I locality, Minnesota.

Remarks. The specimens from Hoisington III locality are less variable in leaf shape and they are less abundant than those from the Courtland I locality, Minnesota.

\section{Genus SAPINDOPSIS (Fontaine) Dilcher and Basson, 1990}

Type species. Sapindopsis magnifolia Fontaine, 1889 (designated by Dilcher and Basson, 1990)

Sapindopsis powelliana (Lesquereux) comb. nov. Figures 13-16 

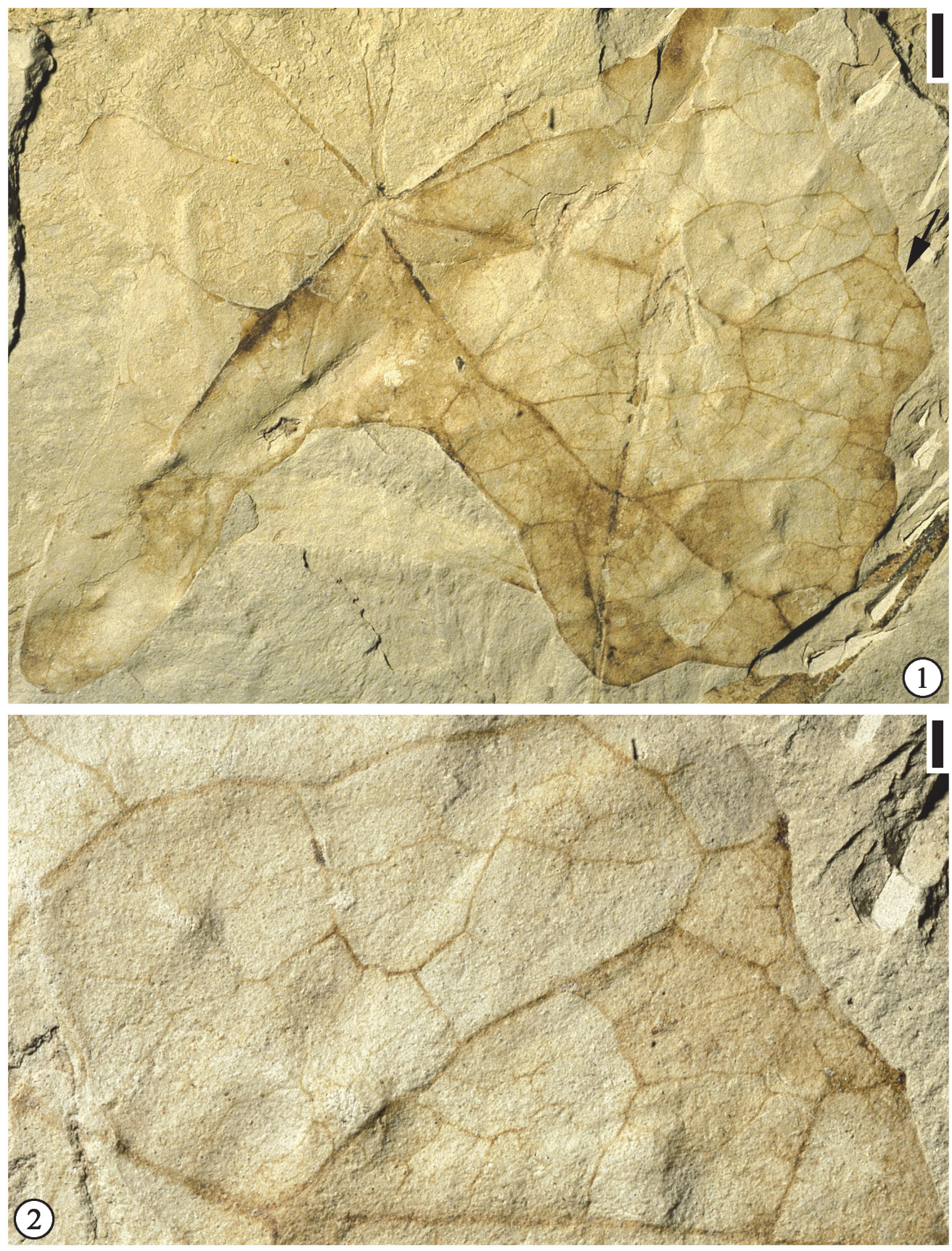

FIGURE 12. Paleonelumbo cf. macroloba Knowlton, 1930. 1, UF15826-24649, specimen showing primary venation (scale bar equals $5 \mathrm{~mm}$ ) and $\mathbf{2}$, enlargement to show high order venation and toothed margin (scale bar equals 1 $\mathrm{mm})$.

Basionym. Rhus powelliana Lesquereux (1892, p. 155, plate 56, figures 4,5 ).

Emended specific diagnosis. Leaf compound, trifoliolate or paripinnate, consisting of three to six pinnately alternate to opposite leaflets; leaf stipulate, petiole thin; lateral leaflets petiolulate, terminal leaflets petiolulate or sessile, narrow oblong to nar- row elliptic; leaflet margin entire. Primary venation of leaflets pinnate; primary vein multi-stranded, stout to massive, course straight. Secondary venation eucamptodromous or slightly brochidodromous; intersecondary veins common, composite. Tertiary veins thick relative to secondary veins, predominately percurrent, slightly convex; arrange- 


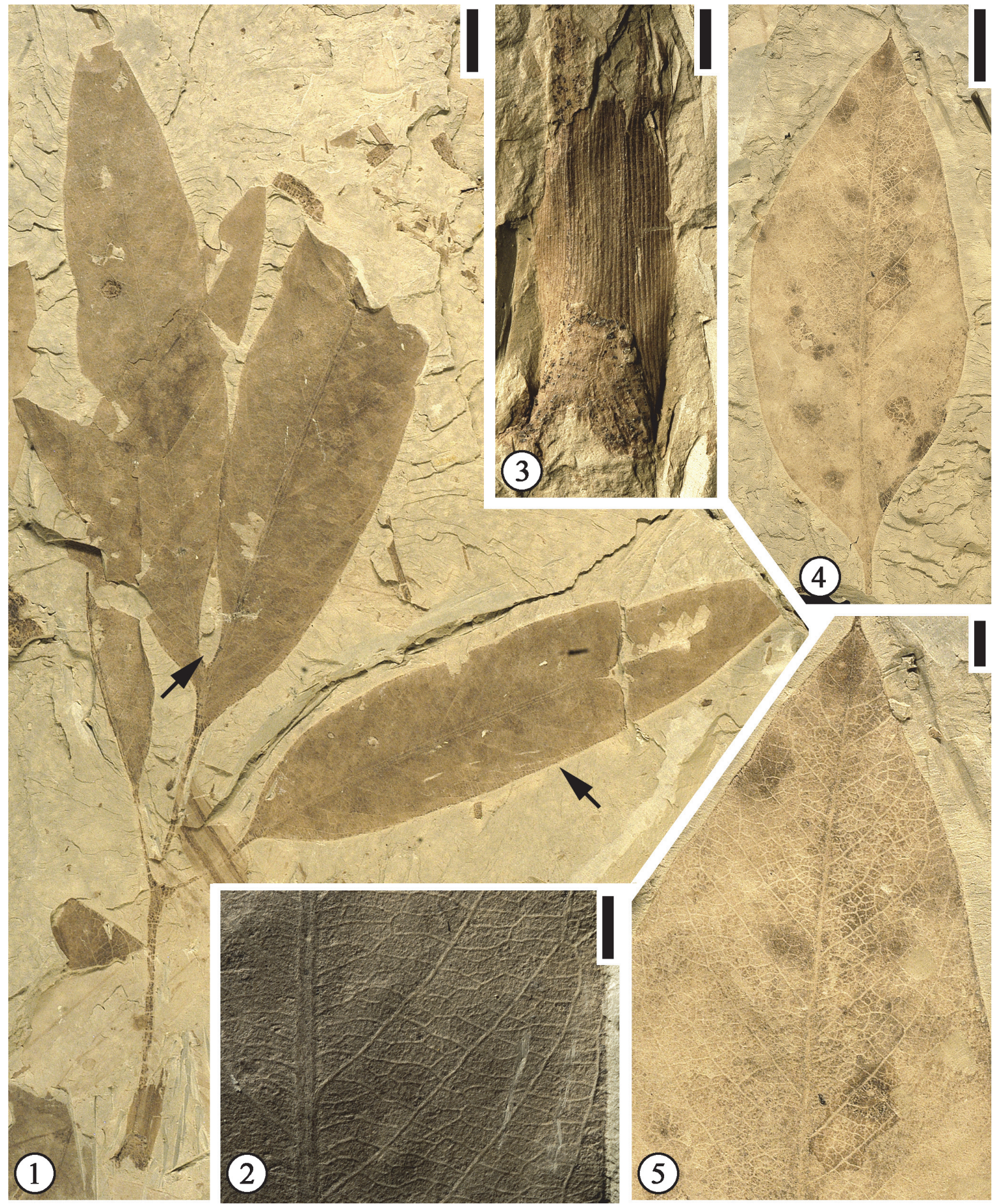

FIGURE 13. Sapindopsis powelliana (Lesquereux) comb. nov. 1, UF15706-14830. leaf with four leaflets. Note two ultimate leaflets appearing to be bilobed (indicated by arrow on the left), two oppositely arranged lateral leaflets, and stipule at the base. Scale bar equals $1 \mathrm{~cm}$. 2, Enlargement of Figure 13.1 (indicated by arrow on the right) to show secondary and tertiary venation. Scale bar equals $2 \mathrm{~mm}$. 3. Enlargement to of Figure 13.1 to show venation of the stipule. Scale bar equals $2 \mathrm{~mm}$. 4, UF15706-14814, an elliptic leaflet with acuminate apex. Scale bar equals $1 \mathrm{~cm} . \mathbf{5}$, Enlargement of Figure 13.4 to show secondary and tertiary venation. Scale bar equals $3 \mathrm{~mm}$. 


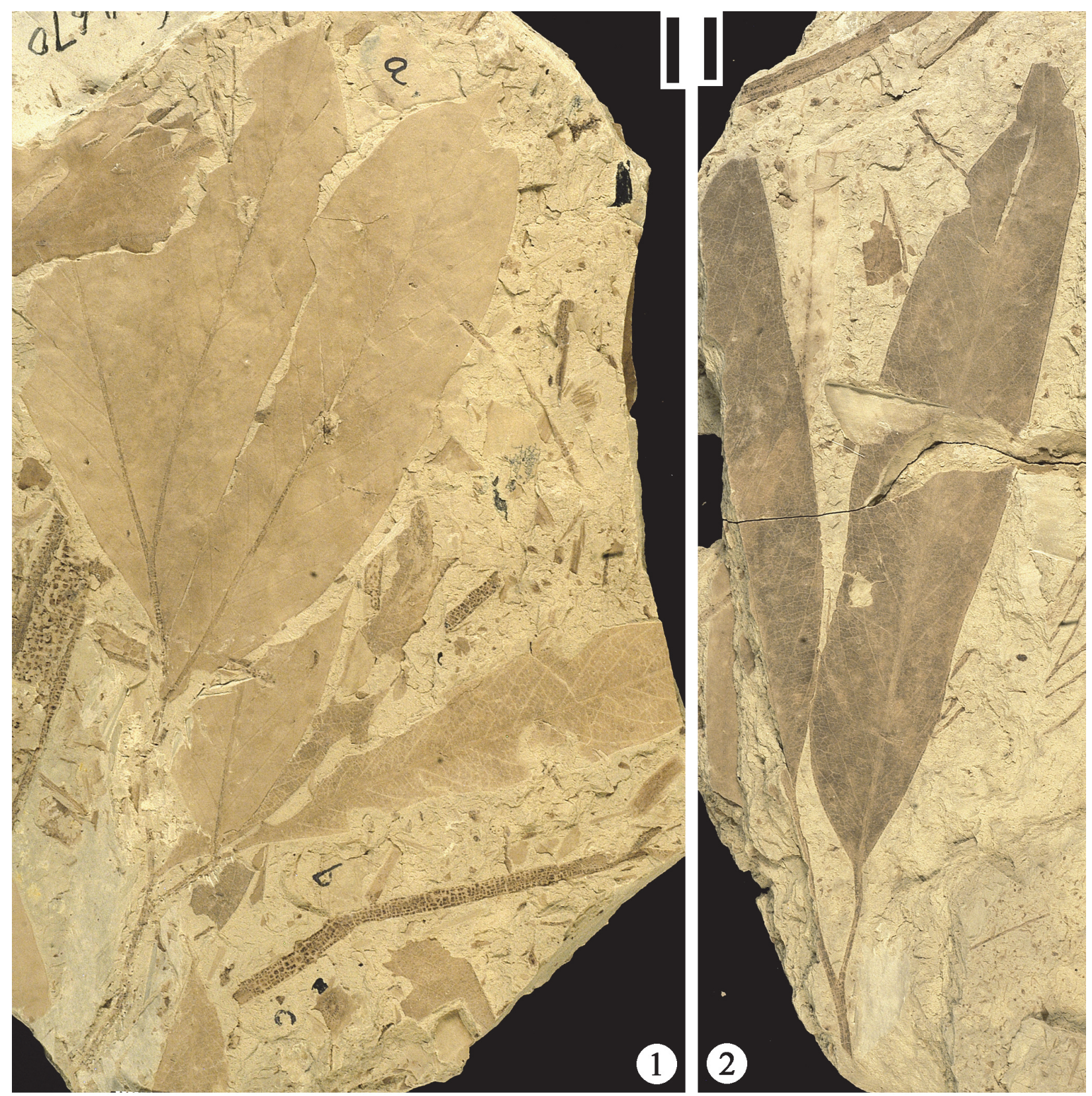

FIGURE 14. Sapindopsis powelliana (Lesquereux) comb. nov. 1, UF15706-24670, leaf with three leaflets. Note bilobed ultimate leaflet. Scale bar equals $1 \mathrm{~cm}$. 2, UF15706-4812, leaf with narrow oblong leaflets. Scale bar equals $1 \mathrm{~cm}$.

ment on secondary vein predominately alternate. Quaternary veins orthogonal, forming quadrangular or pentagonal imperfect areoles; veinlets simple, curved or straight.

Description. Leaf compound, trifoliolate (Figure 15) or paripinnate (Figure 16.1); leaflets alternate (Figure 16.1) to opposite (Figures 13.1, 14); leaf stipulate (Figures 13.1, 15), petiole thin, stipules up to $1.5 \mathrm{~cm}$ long and $0.6 \mathrm{~cm}$ wide, with venation parallel to the long axis; leaflets narrow oblong (Fig- ures 13.1, 14.1-2, 15) to narrow elliptic (Figure 13.4); leaflet $6.5 \mathrm{~cm}$ to $13.5 \mathrm{~cm}$ long and $1.5 \mathrm{~cm}$ to $2.5 \mathrm{~cm}$ wide (L/W 4.3 to 5.4 ); leaflet margins entire, structurally reinforced, apex acute to acuminate, base acute and asymmetrical, terminal leaflet tissue decurrent on rachis; two ultimate leaflets oppositely arranged, with outer sides lamina decurrent on rachis (Figure 13.1), giving a bilobed appearance; the apex of the ultimate leaflets sometimes lobed once, with deep sinus extending about $30 \%$ 


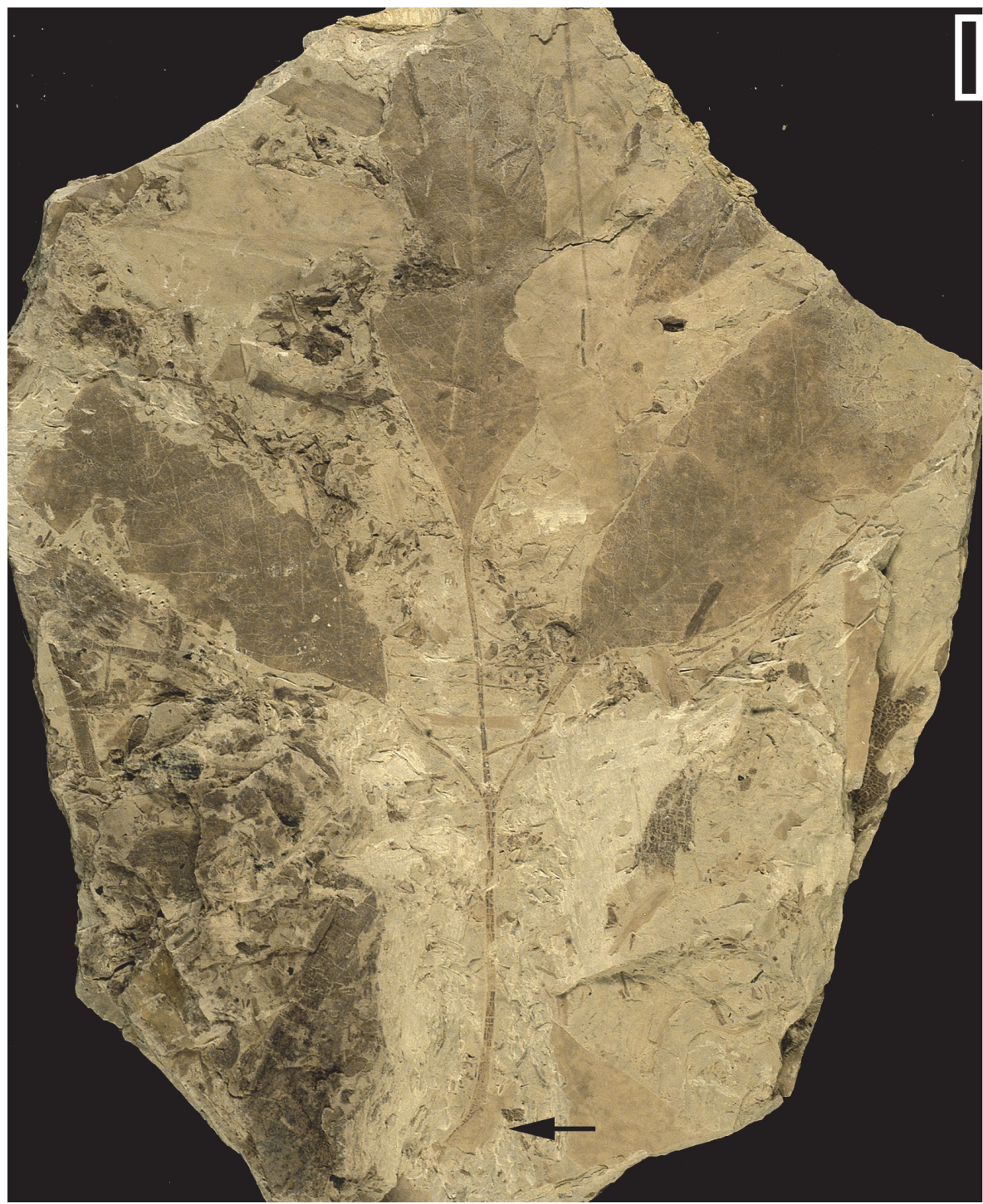

FIGURE 15. Sapindopsis powelliana (Lesquereux) comb. nov. UF15706-24719, leaf with two opposite lateral leaflets, one ultimate leaflet with long and thin petiolule, and a stipule at the base of petiole (indicated by arrow). Scale bar equals $1 \mathrm{~cm}$.

distance of lamina length, bracing of the sinus accomplished by forking of primary veins and then running along the margin within sinus (Figure 14.2). Lateral leaflets petiolulate and terminal leaflets petiolulate or sessile (Figure 14.2); petiolule thin, about $1 \mathrm{~mm}$ wide and up to $3.5 \mathrm{~cm}$ long (Figure 15). Primary venation of leaflets pinnate; primary vein multi-stranded, stout to massive (the ratio of vein width to lamina width is ca. 4\%), course straight. Secondary venation eucamptodromous (Figure 9.2, 9.5; secondary veins upturned and gradually diminishing apically inside the margin, connected to the superadjacent secondary veins by a series of cross veins without forming prominent marginal loops) or slightly brochidodromous; secondary veins moderate in thickness, ca. 15 pairs per leaflet lamina; secondary veins uniformly originate from primary vein at moderate to narrow acute (less than $65^{\circ}$ ) angle, up to 15 pairs per leaflet, subopposite, uniformly curved and diminish near lamina margin; intersecondary veins common, composite (made up of coalesced tertiary vein segments for over $50 \%$ of its length). Tertiary veins thick relative to secondary veins, angle of origin acute-obtuse (AO, lower side of the secondary vein and upper side of the secondary veins), predominately percurrent, slightly convex; arrangement on secondary vein predominately alternate. 


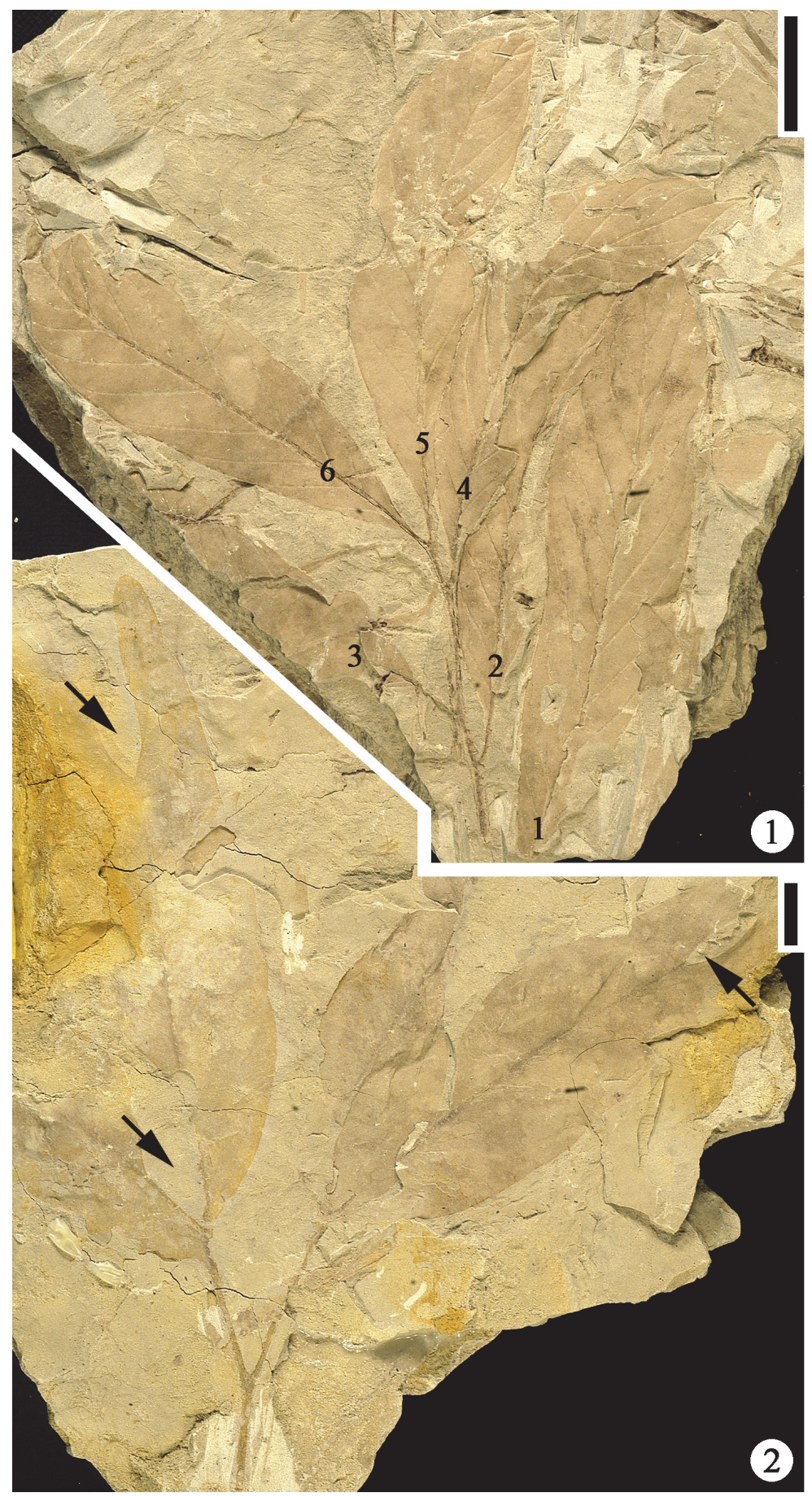

FIGURE 16. Sapindopsis powelliana (Lesquereux) comb. nov. 1, UF15706-24711, leaf with six leaflets (indicated by numbers). Note eucamptodromous secondary venation and strong secondary veins. Scale bar equals $1 \mathrm{~cm}$. 2 , UF15706-24675, leaf with two ultimate lobed leaflets. Note that the apex of each lobe of the two leaflets dissects one more time to form two smaller lobes (indicated by arrows). Scale bar equals $1 \mathrm{~cm}$.

Quaternary veins orthogonal (arising at right angles), forming quadrangular or pentagonal imperfect areoles; veinlets simple, curved or straight.

Number of specimens examined. 110.
Neotype (designated here). UF15706-14830

(Figure 13.1-3).

Other specimens illustrated. UF15706-14814 (Figure 13.4-5); 24670 (Figure 14.1); 4812 (Figure 
14.2); 24719 (Figure 15); 24711 (Figure 16.1); 24675 (Figure 16.2).

Remarks. Lesquereux (1892, p. 155, plate 56, figures 4,5$)$ described two specimens from the Dakota flora and assigned them to an extant genus and established a new species, Rhus powelliana. $\mathrm{He}$ did not designate a holotype specimen for the new species and both specimens he described are currently missing. Based on Article 9.7 of the International Code of Botanical Nomenclature (McNeill et al., 2012), we here designate one specimen from Hoisington III locality, Kansas (UF1570614830; Figure 13.1-3) as the neotype. We transfer this species to the genus Sapindopsis based upon the following diagnostic characters: 1) pinnately compound leaf with terminal lobes or leaflets commonly more or less united at their base (Figure 13.1); 2) distal leaflets with lamina decurrent to the leaf rachis and continuing as a narrow marginal lamina on either side of the rachis (Figure 14.1); 3) the decurrent lamina on the rachis missing entirely toward the leaf base (Figure 14.2); 4) leaflets elliptical to lanceolate-shaped, stout midrib extending to the apex of each leaflet (Figures 13-15); and 5) eucamptodromous secondary venation.

The genus Sapindopsis was established by Fontaine (1889) and the generic diagnosis was emended by Berry (1911d). A total of eight species were originally proposed. Dilcher and Basson (1990) emended the generic diagnosis and proposed that the simple leaf forms (e.g., Sapindopsis cordata Fontaine, 1889 , p. 296, plate 147, figure $1)$, in synonymy with Ficophyllum crassinerve Knowlton (1919) and Sapindopsis elliptica Fontaine (1889, p. 297, plate 147, figure 3 ), and in synonymy with Rogersia longifolia Berry (1911d) should be excluded from the genus Sapindopsis. The large distance between adjacent secondary veins and the well-defined intercostal region by secondary veins in Rogersia are distinct from those of the Sapindopsis powelliana leaves. The other six species, including Sapindopsis magnifolia Fontaine (Fontaine, 1889, p. 297, plate 151, figures 2, 3 , plate 152 , figures 2,3 , plate 153 , figures 2,3 , plate 154 , figures 1,5 , plate 155 , figure 6 ; Berry, 1911 d, p. 471 , plate 86 , figures $1-3$, plate 87 , figure 1 , plate 88 , figure 1 ; Berry, 1922 , p. 214 , plate 55 , figure 5 , plate 56 , plate 57 , figure. 2 , plate 59 , figure 3; Doyle and Hickey, 1976, p. 166-167, figures 17-19; Hickey and Doyle, 1977, p. 35, figures 3338), Sapindopsis variabilis (Fontaine, 1889, plate 151 , figure 1 , plate 152 , figures 1,4 , plate 153 , figure 3 , plate 154, figures 2-4, plate 155 , figures $2-5$; Berry, 1911d, p. 469, plate 83, figures 109, plate
84, figures 1-2, plate 85, figure 1; Berry, 1922, p. 213, plate 55, figures 2-4), Sapindopsis parvifolia Fontaine (Fontaine, 1889, p. 300, plate 154, figure 6), Sapindopsis brevifolia Fontaine (Fontaine, 1889 , p. 300 , plate 153 , figure 4 , plate 155 , figures 1,7 , plate 163, figure 3; Berry, 1911d, p. 473, plate 87, figures 2-5; Berry, 1922, p. 216, plate 55, figure 1 , plate 59 , figure 1), Sapindopsis tenuinervis Fontaine (Fontaine, 1889, p. 301, plate 153, figure 1), and Sapindopsis obtusifolia Fontaine (Fontaine, 1889 , p. 301 , plate 156 , figure 13 , plate 159 , figures 3-6), can be distinguished from Sapindopsis powelliana by their sessile leaflets. Sapindopsis belviderensis Berry (Berry, 1922a, p. 216-217, plates 49-54; Hickey and Doyle, 1977, p. 35-36, figures 39-40) has toothed leaflets which is different from Sapindopsis powelliana.

Sapindopsis powelliana is similar to a specimen (Sapindopsis sp.) illustrated as the frontispiece by Hickey and Doyle (1977). This specimen is from Red Point, Cecil County, Maryland (upper Subzone II-B; late Albian), and it may belong to the same species. They are similar in that both species have lateral leaflets with long petiolules and lobed terminal leaflets.

Dilcher and Basson (1990) described one species (also see Krassilov and Bacchia, 2000), Sapindopsis anhouryi from the Nammoura locality, Lebanon. The stipules of this species are similar to those of $S$. powelliana leaves but they differ in that the leaflets of Sapindopsis powelliana are petiolulate and the secondary venation is eucamptodromous. Well-defined intercostal regions by secondary veins and intramarginal veins are also absent from the leaflets of Sapindopsis powelliana.

Huang and Dilcher (1994) described four types of pinnately lobed leaves from the Cheyenne Sandstone. Of these leaves, Sapindopsis sp. B is similar to the trifoliate leaf (Figure 15) from the Hoisington III locality. Unfortunately, it is difficult to compare them in detail because no venation higher than the second order can be observed for the Cheyenne Sandstone specimens.

Sapindopsis powelliana leaves can be distinguished from other Cretaceous species of Sapindopsis reported around the world by its entire leaflet margin, petiolulate leaflets, eucamptodromous secondary venation, and predominately percurrent tertiary venation. These species include, Sapindopsis cf. Sapindopsis magnifolia/variabilis Fontaine (Upchurch et al., 1994, p. 40, figures 5457), Sapindopsis minutifolia Upchurch et al. (1994, p. 41, figures 58, 59), Sapindopsis lebanensis Krassilov and Bacchia (Krassilov and Bacchia, 
2000, p. 782, figures 8, 9A-D; Golovneva, 2007, p. 1081, plate 3, figure 1), Sapindopsis neuburgae Golovneva (2007, p. 1081, plate 3, figure 1), Sapindopsis janschinii Golovneva (2007, p. 1081, plate 3, figures 2-5, plate 4), Sapindopsis kryshtofovichii Golovneva (2007, p. 1083, plate 5, figures 1-4; plate 6, figures 1-4).

Doyle and Hickey (1976) and Dilcher and Basson (1990) recognized two distinct types of Sapindopsis leaves. One type has fused terminal leaflets and decurrent lamina tissue on the rachis. The other type rarely has fused terminal leaflets and frequently the leaflets are petiolulate and lack any decurrent lamina tissue on the rachis. Most leaves of Sapindopsis powelliana belong to the second type but with occasional exceptions (Figure 14.1). As suggested by Dilcher and Basson (1990), a detailed study of the leaf types of Sapindopsis is needed in order to separate these forms into distinct genera. A reexamination of the actual stratigraphic positions of these leaf forms is also needed in order to understand the direction of leaf evolution.

Compared with all other species assigned to Sapindopsis, S. powelliana seems to have the highest leaf venation rank. Most other species of Sapindopsis from the Potomac Group have the second leaf rank. This is in agreement with Doyle and Hickey (1976) and Hickey and Doyle's (1977) summary of the Potomac leaf sequence because the Dakota Formation is younger than the Potomac Group.

Although the genus Sapindopsis was originally proposed by Fontaine (1889) as a member of the Sapindaceae, there is no evidence that Sapindopsis is more closely related to extant Sapindaceae than to other groups (Crane, 1989; Crane et al., 1993; Upchurch et al., 1994). Many features of leaf architecture and cuticular anatomy in fossil Sapindopsis, and its co-occurrence with platanoid reproductive structures show that they are probably more closely related to Platanaceae (Hickey and Wolfe, 1975; Hickey and Doyle, 1977; Upchurch, 1984; Upchurch and Dilcher, 1990; Wang et al., 2011).

\section{Sapindopsis retallackii sp. nov.} Figure 17

Specific diagnosis. Leaf compound, with three or four leaflets; most commonly three leaflets closely arranged on the distal portion of the rachis, occasionally with one leaflet attached at some distance proximally on rachis; rachis thin. Leaflet lorate, always curved abaxially; apex attenuate; base normal acute; lateral leaflets sessile and terminal leaf- lets petiolulate; margin entire, usually revolute. Primary venation pinnate; primary vein stout; course straight (medial leaflet) or recurved (lateral leaflets). Secondary venation brochidodromous; secondary veins thin relative to primary vein; opposite to subopposite, decurrent; angle of divergence acute, joining superadjacent secondary veins to form a loop enclosing an intercostal area, with two series of loops (tertiary and quaternary in order) in excostal region; exmedial branches of secondary veins common, forming tertiary veins. Intersecondary veins common. Tertiary vein moderate; orthogonal reticulate but tending to be percurrent, retroflexed. Quaternary veins random reticulate, forming incompletely closed meshes. Veinlets simple, linear.

Description. Leaflet lamina base symmetrical. Form lanceolate, L/W $>5,10 \mathrm{~cm}$ long (estimated length) and $1.8 \mathrm{~cm}$ wide. Apex missing. Base normal, acute; petiolule $1 \mathrm{~cm}$ long and $1 \mathrm{~mm}$ wide. Margin entire. Petiole normal, short, $0.8 \mathrm{~cm}$ long and $0.5 \mathrm{~mm}$ wide. Primary venation pinnate; primary vein stout, slightly curved, up to $0.5 \mathrm{~mm}$ wide at the widest portion of lamina. Secondary venation festooned brochidodromous; secondary vein fine relative to primary vein; secondary veins diverging from primary vein at narrow acute angles, with lowest one to two pairs more acute than pairs above; secondary veins slightly recurved after diverging from primary vein, then extending a distance to about one fourth to one half of half lamina before joining superadjacent secondary or intersecondary veins to form two series of loops in the excostal region. Intersecondary veins common, one to three pairs per intercostal region; intersecondary veins simple or occasionally forking at variable distance after diverging from primary vein; intersecondary veins almost the same width as secondary veins. Tertiary veins hair-like; diverging from primary veins, exmedial (lower) side of secondary veins or intersecondary veins at moderate acute to narrow acute angles, predominately exmedially ramified, orientation parallel to secondary or intersecondary veins, connected by cross veins of the same order.

Number of specimens examined. 30 .

Holotype. UF15706-3153 (Figure 17).

Species epithet. In recognition of Greg Retallack and his contribution to the Dakota Formation geology and paleobotany.

Occurrences. Hoisington III locality, Kansas.

Remarks. Only one specimen, representing a terminal leaflet of a compound leaf, is observed from the Hoisington III locality. The venation pattern matches that of the compound leaves from the 


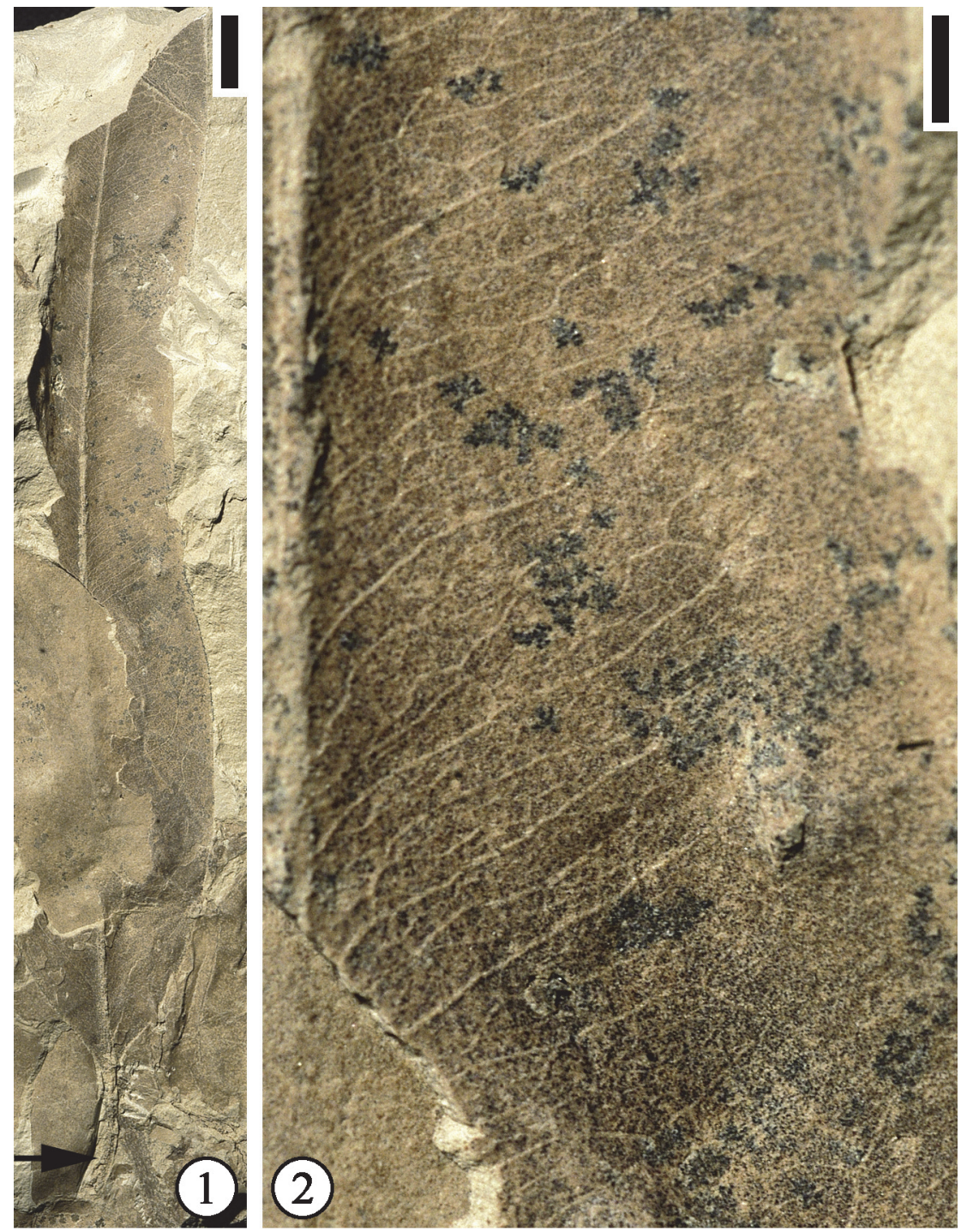

FIGURE 17. Sapindopsis retallackii sp. nov. 1, UF15706-3153, showing a leaflet with entire margin. Note the petiolule at the base (indicated by arrow). Scale bar equals $5 \mathrm{~mm}$. 2, Enlargement of Figure 17.1 to show numerous thin secondary and intersecondary veins. Scale bar equals $1 \mathrm{~mm}$.

Springfield locality and Pleasant Dale locality, Nebraska (Wang and Dilcher, in preparation).

Sapindopsis retallackii is similar to Sapindopsis sp. A (Huang and Dilcher, 1994) in having three leaflets but they differ in that $S$. retallackii occasionally has four lorate leaflets, and brochidodromous secondary venation. Sapindopsis retallackii can be distinguished from other Sapindopsis species (see previous section) by the following suite of characters: compound leaf with petiolulate terminal leaflets, sessile lateral leaflets, lorate leaflet shape, brochidodromous secondary venation, the presence of exmedial branches of secondary veins that branch into tertiary veins, and common intersecondary veins.
Clade ROSIDS Angiosperm Phylogeny Group, 2009

Genus ANISODROMUM Upchurch and Dilcher, 1990

Type species. Anisodromum wolfei Upchurch and Dilcher, 1990

Anisodromum wolfei Upchurch and Dilcher 1990 Figure 18

Description. Leaflet lamina and base symmetrical. Shape narrow ovate or elliptic, L/W 2 to 2.6, lamina 3 to $4.7 \mathrm{~cm}$ wide and 8 to $9 \mathrm{~cm}$ long. Apex missing. Base obtuse. Margin entire. Observed petiolule with a 0.2 to $0.3 \mathrm{~mm}$ wide decurrent lamina tissue; petiole $0.5 \mathrm{~mm}$ wide and $2 \mathrm{~mm}$ long. Primary vena- 

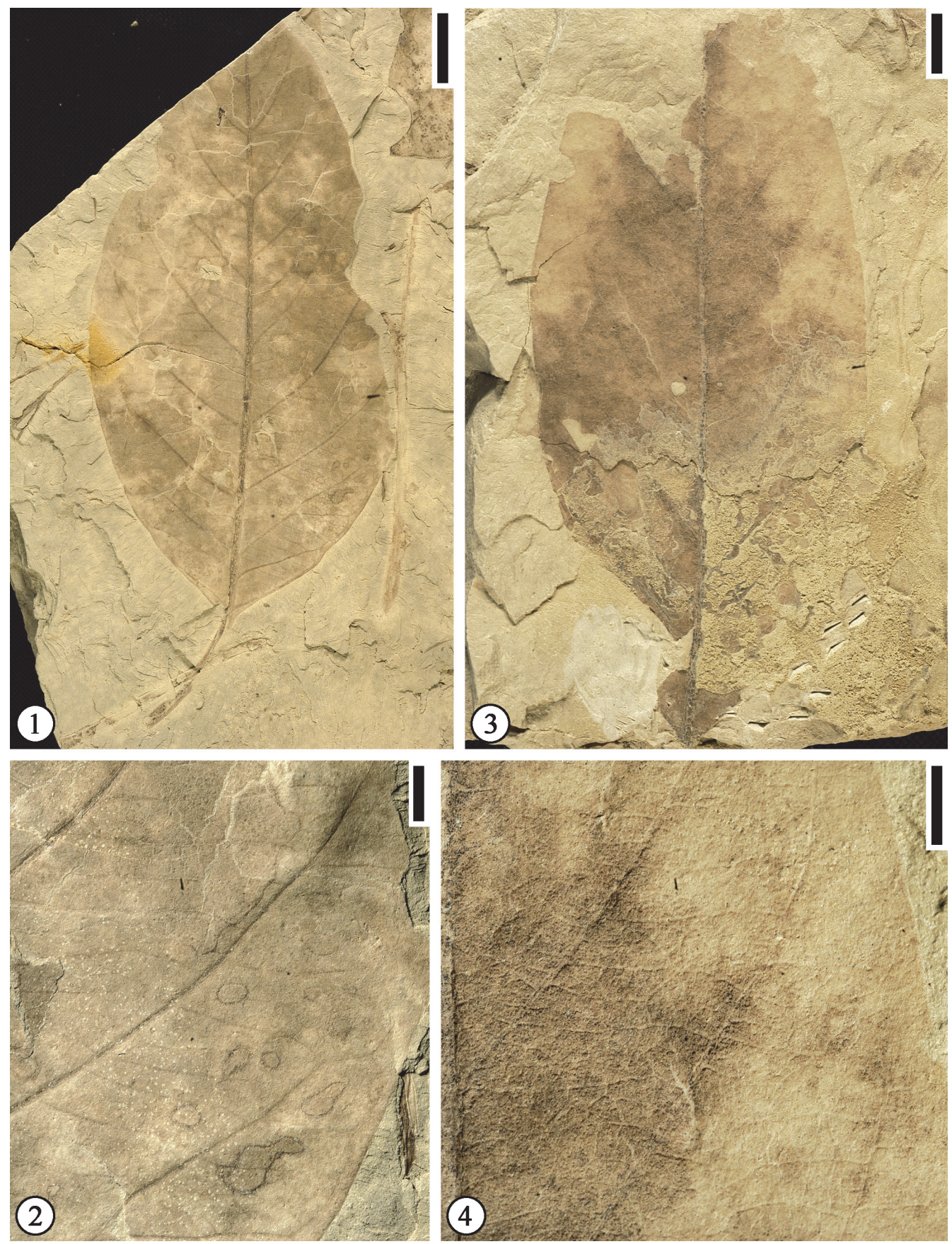

FIGURE 18. Anisodromum wolfei Upchurch and Dilcher, 1990. 1, UF15706-14818, general leaflet shape. Note long petiolule. Scale bar equals $1 \mathrm{~cm}$. 2, Enlargement of Figure 18.1 to show strong secondary veins and percurrent tertiary veins oriented perpendicular to the primary vein. Scale bar equals $2 \mathrm{~mm}$. 3, UF15706-24566, general leaflet shape. Scale bar equals $5 \mathrm{~mm}$. 4, Enlargement of Figure 18.3 to show percurrent tertiary veins oriented almost perpendicular to the primary vein. Scale bar equals $2 \mathrm{~mm}$.

tion of leaflets pinnate; primary vein stout, multistranded, course straight. Secondary venation predominately eucamptodromous; secondary veins moderate relative to primary vein, multi-stranded, ca. nine pairs per lamina, opposite or slightly subopposite, decurrent; angle of divergence moderate acute $\left(45^{\circ}\right.$ to $\left.65^{\circ}\right)$, with basal pairs at slightly more obtuse angles; basal secondary veins joining superadjacent secondary veins or their exmedial branches to form loops very close to margin; other secondary veins uniformly curved and diminishing near margin; adjacent secondary veins connected 
by percurrent tertiary veins. Tertiary veins percurrent, moderate relative to secondary veins; angle of origin $\mathrm{AO}$ (acute on exmedial side of secondary vein and obtuse on admedial side of secondary veins) or RO (right on primary vein and obtuse on admedial side of secondary vein); course predominately straight, oriented almost at right angle with primary vein; arrangement close (interval between veins less than $0.5 \mathrm{~cm}$ ). Quaternary vein orthogonal reticulate. Veins of higher order not observed.

Number of specimens examined. 3 .

Specimens illustrated. UF15706-14818 (Figure 18.1-2); 24566 (Figure 18.3-4).

Remarks. Upchurch and Dilcher (1990) described six specimens from the Rose Creek locality, Nebraska and they proposed that the compound leaves most closely resemble Sapindopsis but they differ in that Anisodromum wolfei has secondary venation that shows asymmetric behavior and much less brochidodromous looping, more percurrent and closely spaced tertiary venation, and a structurally reinforced margin. These characters were interpreted as significant at generic level by analogy to extant pinnately compound Rosidae, where genera are distinguished on the basis of secondary, tertiary, and marginal venation (Upchurch and Dilcher, 1990).

\section{Anisodromum upchurchii sp. nov.}

Figure 19.1-2

Specific diagnosis. Lamina base acute, decurrent. Margin entire. Primary venation pinnate; primary vein stout, multi-stranded, straight. Secondary venation brochidodromous, secondary veins moderate relative to primary vein, opposite, subopposite or alternate; angle of divergence wide acute, uniformly curved apically; secondary vein spacing distant. Intersecondary veins common, usually opposite to a secondary vein on the other side of lamina. Tertiary veins moderate relative to secondary veins, percurrent, course straight, oriented almost at right angles with primary vein.

Description. Incomplete leaves observed. Apex missing. Base acute, decurrent. Margin entire. Primary venation pinnate; primary vein stout, multistranded, straight. Secondary venation brochidodromous, secondary veins moderate relative to primary vein, ca. six pairs per lamina, opposite, subopposite or alternate; angle of divergence wide acute, with lowest pair more acute than pairs above, uniformly curved apically; secondary vein spacing distant (distance between veins 1 to 1.5 $\mathrm{cm}$. Intersecondary veins common, one or two per intercostal region; extending less than one half distance of half lamina, usually opposite to a second- ary vein on the other side of lamina. Tertiary veins moderate relative to secondary veins, percurrent, course straight; angle of origin AO (acute on exmedial side and obtuse on admedial side of secondary veins or intersecondary vein) or RO (right on primary vein and obtuse on admedial side of secondary or intersecondary veins), primary vein-tertiary vein angle almost right $\left(90^{\circ}\right)$; tertiary vein interval close (interval between veins less than $0.5 \mathrm{~cm}$ ). Veins of higher order not observed.

Number of specimens examined. 4.

Holotype. UF15706-24576 (Figure 19.1-2).

Derivation of epithet. In honor of Garland R. Upchurch in recognition of his contributions to Dakota Formation angiosperm paleobotany.

Remarks. Anisodromum upchurchii differs from Anisodromum wolfei in that it has large angles of divergence for secondary veins, large distance between secondary veins, fewer secondary veins, and intersecondary veins arranged opposite to secondary vein on the opposite side of the lamina. Anisodromum upchurchii and $A$. schimperi are similar in that they both have irregularly spaced secondary veins. They differ in that the secondary venation of $A$. schimperi is festooned brochidodromous and its tertiary veins are orthogonally reticulate near primary vein.

The wide divergence angle of the secondary veins and the primary-tertiary vein angle of Anisodromum upchurchii are similar to Morphotype CM05 (Magnoliaephyllum sp.) from the mid-Cretaceous Cedar Mountain Formation of Utah, USA (Harris and Arens, 2016, p. 646-648, figure 4.1-3). They differ in that the divergence angle of secondary veins is larger and the percurrent tertiary veins is less dense in Anisodromum upchurchii compared with those of Morphotype CM05.

It is unknown if the specimens from the Hoisington III locality represent simple or compound leaves. Therefore, we tentatively assign these specimens to the genus Anisodromum. Future collection with better preserved specimens may confirm this assignment or help separate them from this genus.

Anisodromum schimperi (Lesquereux) comb. nov. Figure 19.3-4

Basionym. "Persea" schimperi Lesquereux (1892, p. 103 , plate 16 , figure 5 ).

Emended specific diagnosis. Lamina margin entire. Primary venation pinnate; primary vein stout, multi-stranded, course straight. Secondary venation festooned brochidodromous; secondary veins moderate relative to primary veins, subopposite to alternate, decurrent, spacing irregular, with 

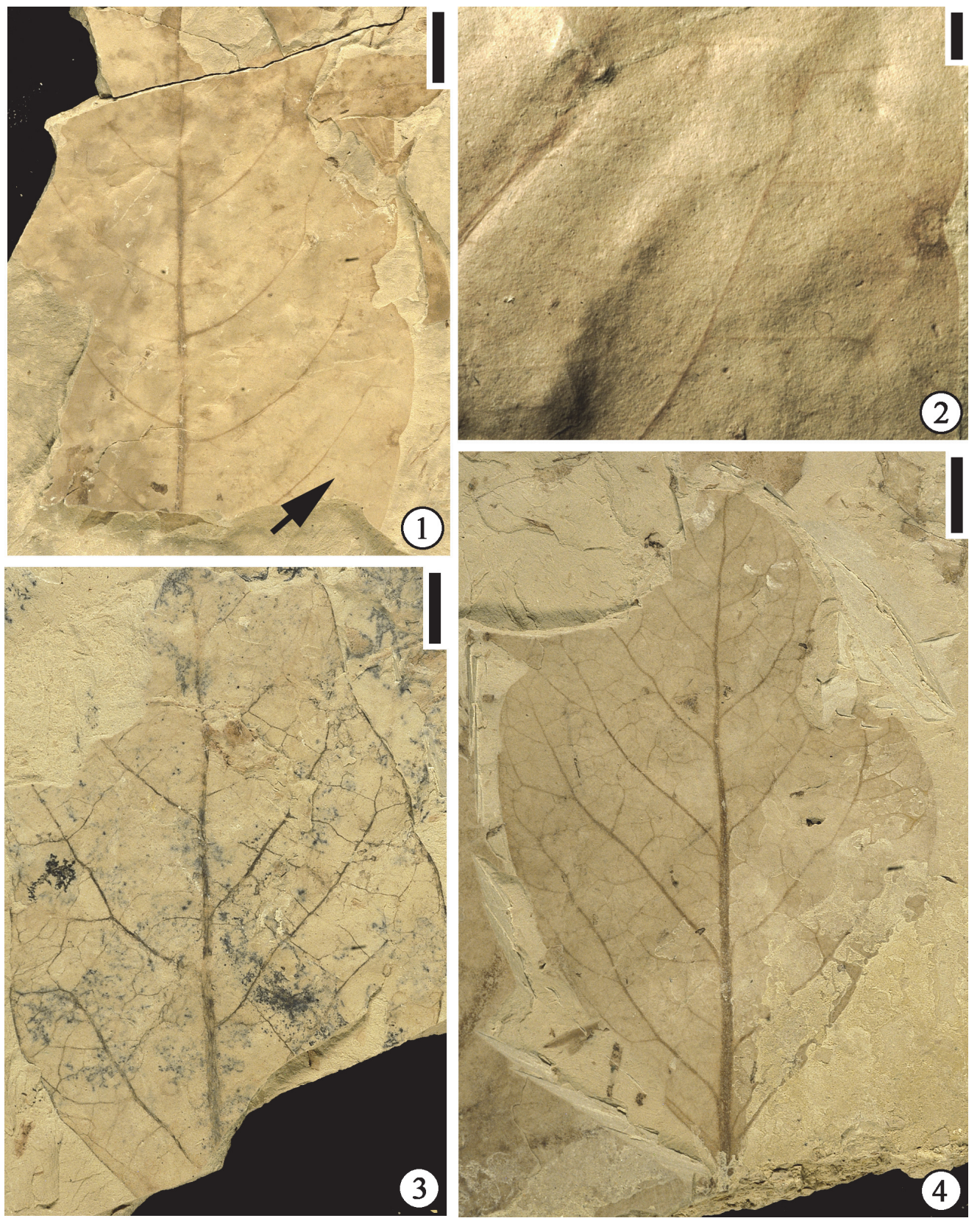

FIGURE 19. 1-2, Anisodromum upchurchii sp. nov., UF15706-24576, middle portion of lamina showing strong primary and secondary veins (scale bar equals $1 \mathrm{~cm}$ ) (1) and enlargement of an area in Figure 19.1 (indicated by arrow) to show percurrent tertiary veins (scale bar equals $2 \mathrm{~mm}$ ) (2). 3-4, Anisodromum schimperi (Lesquereux) comb. nov., UF15706-24635, leaf showing uneven spacing of secondary veins and reticulate tertiary veins (scale bar equals 5 mm) (3) and; UF15706-24633, leaf showing secondary venation and reticulate tertiary veins (scale bar equals $5 \mathrm{~mm}$ ) (4).

one side more closely spaced than the other side; secondary vein curved apically, joining tertiary veins from superadjacent secondary veins to form two series of loops. Tertiary veins moderate relative to secondary veins, predominately percurrent, orthogonal reticulate near primary vein; course irregular, straight or sinuous; primary-tertiary vein angle oblique.

Description. Whole lamina and base symmetrical, lamina elliptic, L/W 1.5, lamina $2.9 \mathrm{~cm}$ to $3.1 \mathrm{~cm}$ wide and $4.5 \mathrm{~cm}$ to $5.5 \mathrm{~cm}$ long. Apex obtuse. Base acute normal. Margin entire. Petiole not observed. Primary venation pinnate; primary vein stout, multi- 
stranded, course straight. Secondary venation festooned brochidodromous; secondary veins moderate relative to primary vein, ca. seven pairs per lamina, subopposite to alternate, decurrent, spacing irregular, with one side more close than the other side; angle of divergence narrow acute to moderate acute $\left(45^{\circ}\right.$ to $\left.65^{\circ}\right)$, with one side apparently more acute than those of the other side; secondary vein curved apically, joining tertiary veins from superadjacent secondary veins to form two series of loops. Tertiary veins moderate relative to secondary veins, predominately percurrent, orthogonal reticulate near primary vein; angle of origin (AO); course irregular, straight or sinuous; primarytertiary vein angle oblique. Veins of higher order not observed.

Number of specimens examined. 2.

Neotype (designated here). UF15706-24633 (Figure 19.4).

Other specimens illustrated. UF15706-24635 (Figure 19.3).

Remarks. Characters such as entire margin, multistranded primary vein, and festooned brochidodromous secondary venation indicate the affinity of this species with Magnoliales, but the uneven secondary vein spacing may indicate these specimens may represent leaflets of a compound leaf.

Lesquereux (1893, p. 103, plate 16, figure 5) described one specimen from a locality in Minnesota, USA and assigned it to the extant genus Persea. In this report, we retain Lesquereux's species epithet and transfer his specimen to Anisodromum. Because his original specimen is lost and he did not designate a type, we here emend his species diagnosis and designate a specimen from the Hoisington III locality as the neotype.

Genus CITROPHYLLUM Berry, 1911a

Type species. Citrophyllum aligera Lesquereux, 1892 (designated by Upchurch and Dilcher 1990)

\section{Citrophyllum aligera Lesquereux, 1892}

Figure 20

*1892 Ficus aligera Lesquereux, p. 84, pl. 10, figs. 3-6.

*1909 Citrophyllum aligerum (Lesquereux) Berry: Berry, p. 258, pl. 18a, figs. 1-8.

*1911a Citrophyllum aligera (Lesquereux) Berry: Berry, p. 169, pl. 21, figs. 1-8.

Emended specific diagnosis. Leaf simple, whole lamina and base symmetrical. Apex obtuse. Margin entire. Petiole aliform, base inflated; demarcation between lamina wing and lamina distinct. Primary venation pinnate; primary vein stout, course straight. Secondary venation festooned brochi- dodromous; secondary veins thin relative to primary vein, subopposite to alternate; angle of divergence moderate acute; secondary veins uniformly curved, joining exmedial branches of superadjacent secondary vein at right or obtuse angles to form two series of loops. Intersecondary veins common, simple. Tertiary veins random reticulate, but tending to be percurrent near leaf margin. Quaternary and quinternary veins random reticulate.

Description. Leaf simple, whole lamina and base symmetrical. Form ovate to narrow elliptic, L/W 1.3 to 2.6, lamina 3 to $6 \mathrm{~cm}$ wide and $8 \mathrm{~cm}$ long. Apex obtuse. Base normal obtuse or cuneate. Margin entire. Petiole aliform, base inflated; petiole 0.5 to $1.8 \mathrm{~mm}$ wide and $2.5 \mathrm{~cm}$ to $4 \mathrm{~cm}$ long; lamina wing $0.2 \mathrm{~mm}$ to $1.8 \mathrm{~mm}$ wide on each side; demarcation between lamina wing and lamina distinct. Primary venation pinnate; primary vein stout, $0.5 \mathrm{~mm}$ to 1 $\mathrm{mm}$ wide, course straight. Secondary venation festooned brochidodromous; secondary veins thin relative to primary vein, ca. nine pairs per leaf lamina, subopposite to alternate; angle of divergence moderate acute (ca. $50^{\circ}$ ), with lowest pair more obtuse than pairs above; secondary vein uniformly curved, joining exmedial branches of superadjacent secondary vein at right or obtuse angles to form two series of loops. Intersecondary veins common, one to two between adjacent secondary veins, simple, extending a distance of one third to one half of half lamina. Tertiary veins random reticulate, but tending to be percurrent near leaf margin. Quaternary and quinternary veins random reticulate.

Number of specimens examined. 6 .

Neotype (designated here). UF15706-24646 (Figure 20.1).

Other specimens illustrated. UF15706-24645 (Figure 20.2); 24332 (Figure 20.3-4).

Remarks. Citrophyllum aligera differs from Citrophyllum doylei, a species established by Upchurch and Dilcher (1990, p.43-45, plate 27, figures 1, 3, 4; text-figure 21), in having a longer petiole and festooned brochidodromous secondary venation. Some specimens from the Hoisington III locality occasionally don't have alate petioles. These specimens may represent the further reduction of lamina tissue on the petiole.

The genus Citrophyllum was established by Berry (1909) to accommodate fossil leaves with elliptical to ovate or ovate-lanceolate, coriaceous leaves, with entire or slightly undulate margins and stout conspicuously alate petioles. These characters are generally similar to those of the modern genus Citrus. Berry (1909, p. 258) transferred Les- 

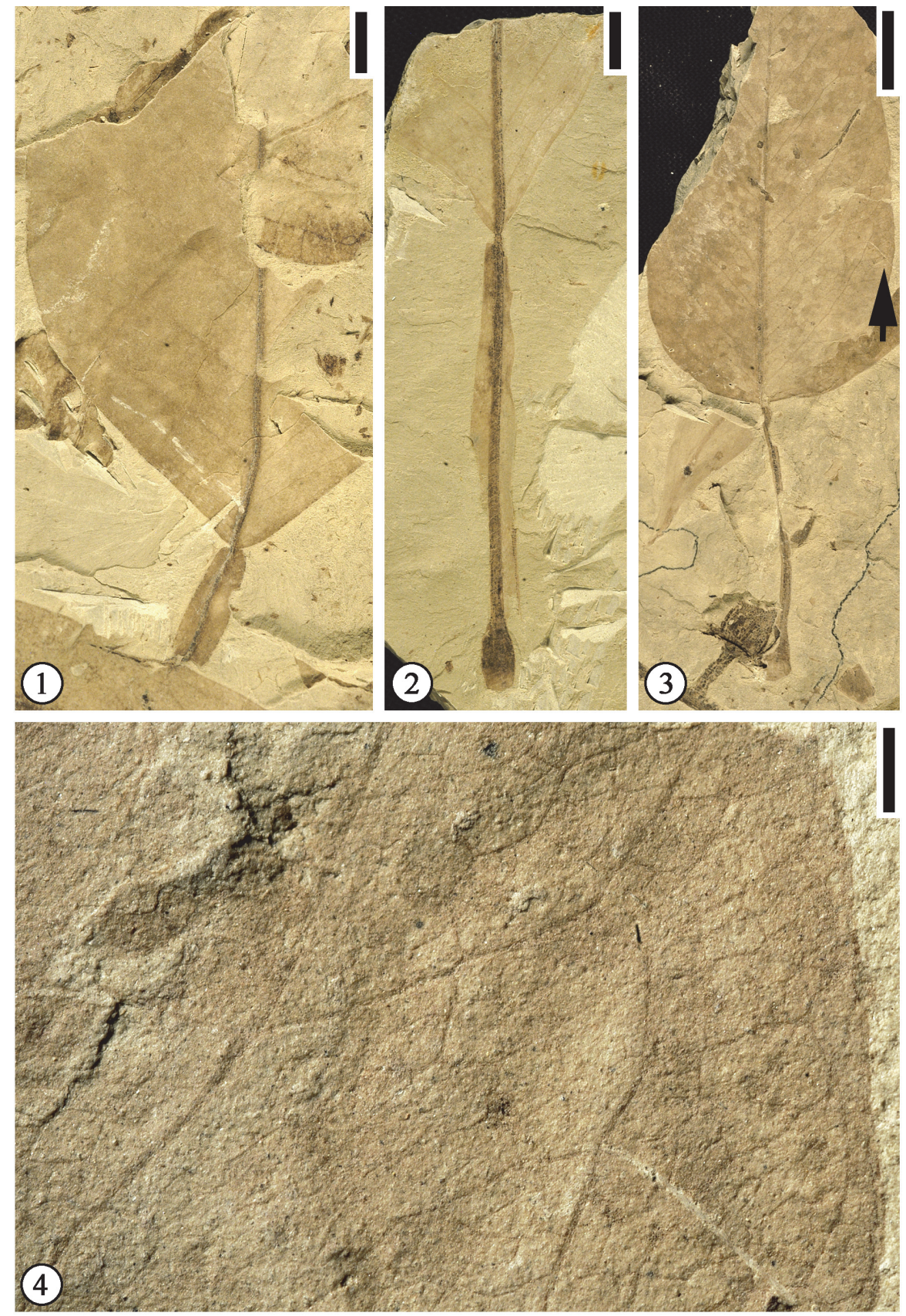

FIGURE 20. Citrophyllum aligera Lesquereux, 1892. 1, UF15706-24646, base of leaf showing lamina wing on petiole. Scale bar equals $5 \mathrm{~mm}$. 2, UF15706-24645, base of leaf showing a long petiole with lamina wing and inflated petiolar base. Scale bar equals $5 \mathrm{~mm}$. 3, UF15706-24332. leaf with a long petiole with thin lamina wing and inflated petiolar base. Scale bar equals $1 \mathrm{~cm} .4$, Enlargement of an area in Figure 20.3 (indicated by arrow) to show looping marginal veins. Scale bar equals $1 \mathrm{~mm}$.

quereux's (1892) Dakota specimens, originally assigned to the extant genus Ficus, to Citrophyllum. As discussed by Upchurch and Dilcher (1990, p. 44), the modern affinities of the genus Citrophyllum is with Sapindales instead of Rutaceae because it doesn't possess features that characterize Rutaceae. Leaves of Rutaceae have been reported only from the Cenozoic of Asia (Guo, 2011; Xie et al., 2013) and Africa (Pan, 2010), but no Rutaceae fossils have been found from the Cretaceous.

\author{
Clade Unknown \\ Genus WINGIA gen. nov.
}


Generic diagnosis. Leaf simple, irregularly fivelobed; lamina margin with glandular teeth at or near apex of lobes, strongly reinforced; sinus rounded, bracing accomplished by two secondary veins originated from adjacent primary veins; serrations minute, simple, typically three veins entering a tooth, medial vein originating from exmedial side of secondary vein, basal vein tertiary in order and running very close to the margin before entering the tooth, vein of apical side not well developed. Petiole long and thin, enlarged both distally and proximally (perhaps these are pulvini). Primary venation basal actinodromous; primary vein stout to massive, multi-stranded; medial primary vein straight in course; inner lateral primary veins apically curved; outer primary veins apically curved or recurved. Secondary venation predominately brochidodromous or semicraspedodromous when margin is toothed near apex; secondary veins thin relative to primary veins; originating from primary veins at wide acute to angle, straight or slightly curved and then abruptly curved very close to the margin to join superadjacent secondary veins to form rectangular or rhomboidal intercostal regions; Intersecondary veins common, composite. Tertiary veins orthogonal reticulate, forming predominately quadrangular meshes.

Type species. Wingia expansolobum (Upchurch and Dilcher) Wang and Dilcher (designated here).

Derivation of generic name. In honor of Scott Wing in recognition of his contribution to angiosperm paleobotany.

Remarks. Upchurch and Dilcher (1990, p. 48-49, plate 31 , text figure 25) established a new species based upon one specimen from the Rose Creek locality, Nebraska and assigned this species to Dicotylophyllum. This species differs from all other lobed leaves from the Dakota Formation of Kansas, including "Aralia" quinquepartita Lesquereux (1871, p. 302, 1874, plate 15, figure 6) and "Sterculia" lugubris Lesquereux (1883, plate 6, figures 13 ), in having small teeth and five lobes. The genus Dicotylophyllum, first established by Saporta (1894), is heterogeneous and it may only include probable nymphaealean leaves (see Halamski, 2013 , p. $429-430$ for detailed discussion). Therefore, we establish a new genus for this species from the Dakota Formation.

\section{Wingia expansolobum (Upchurch and Dilcher)} comb. nov.

Figures 21-23

Basionym. Dicotylophyllum expansolobum Upchurch and Dilcher (1990, p. 48-49, plate 31, text-figure 25).
Specific diagnosis. Leaf simple, irregularly fivelobed, margin toothed near apex of lobes, serrations minute, simple. Petiole long and thin, enlarged both distally and proximally. Primary venation basal actinodromous. Secondary venation predominately brochidodromous or semicraspedodromous when margin is toothed near apex; typically, one series of loops present in the excostal region if margin is entire; secondary veins below sinus and between adjacent primary veins forming inverted ' $\mathrm{V}$ ' pattern. Intersecondary veins common, composite. Tertiary and quaternary veins orthogonal reticulate, forming predominately quadrangular meshes.

Description. Leaf simple, five-lobed, lamina varies from $3.2 \mathrm{~cm}$ long and $6 \mathrm{~cm}$ wide to $15 \mathrm{~cm}$ long and $15 \mathrm{~cm}$ wide; sinus deep, extending $75 \%$ to $80 \%$ of distance from apex to lamina base; medial lobe narrow obovate, narrow ovate or narrow oblong, symmetrical; lateral lobes asymmetrical, shape irregular, curved apically; outer lobes occasionally underdeveloped (leaf tending to be trilobate); apex of lobes obtuse; base of lamina obtusely cuneate or strongly rounded to give a truncate appearance; margin toothed near apex of lobes, strongly reinforced; sinus rounded, bracing accomplished by two secondary veins originated from adjacent primary veins, these two veins join and then fork to run along the margin; serrations minute, simple; serration type ranging from concave to straight on apical side and straight to convex on basal side, spacing irregular; typically three veins entering a tooth, medial vein originating form exmedial side of secondary vein, basal vein tertiary in order and running very close to the margin before entering the tooth, vein of apical side not well developed. Petiole long, thin, $8 \mathrm{~cm}$ long and $1 \mathrm{~mm}$ wide; pulvini (lower and upper) present; upper pulvinus extending up to $1 \mathrm{~cm}$ proximally along the petiole. Primary venation basal actinodromous; primary veins stout to massive, multi-stranded; medial primary vein straight in course; inner lateral primary veins apically curved; outer primary veins apically curved or recurved. Secondary venation predominately brochidodromous or occasionally semicraspedodromous near apex; secondary veins thin relative to primary veins; originating from primary veins at wide acute angles, straight or slightly curved and then abruptly curved very close to the margin to join superadjacent secondary veins to form rectangular or rhomboidal intercostal regions; typically one series of loops present in the excostal region if margin is entire; secondary veins below sinus and between adjacent primary veins forming inverted 


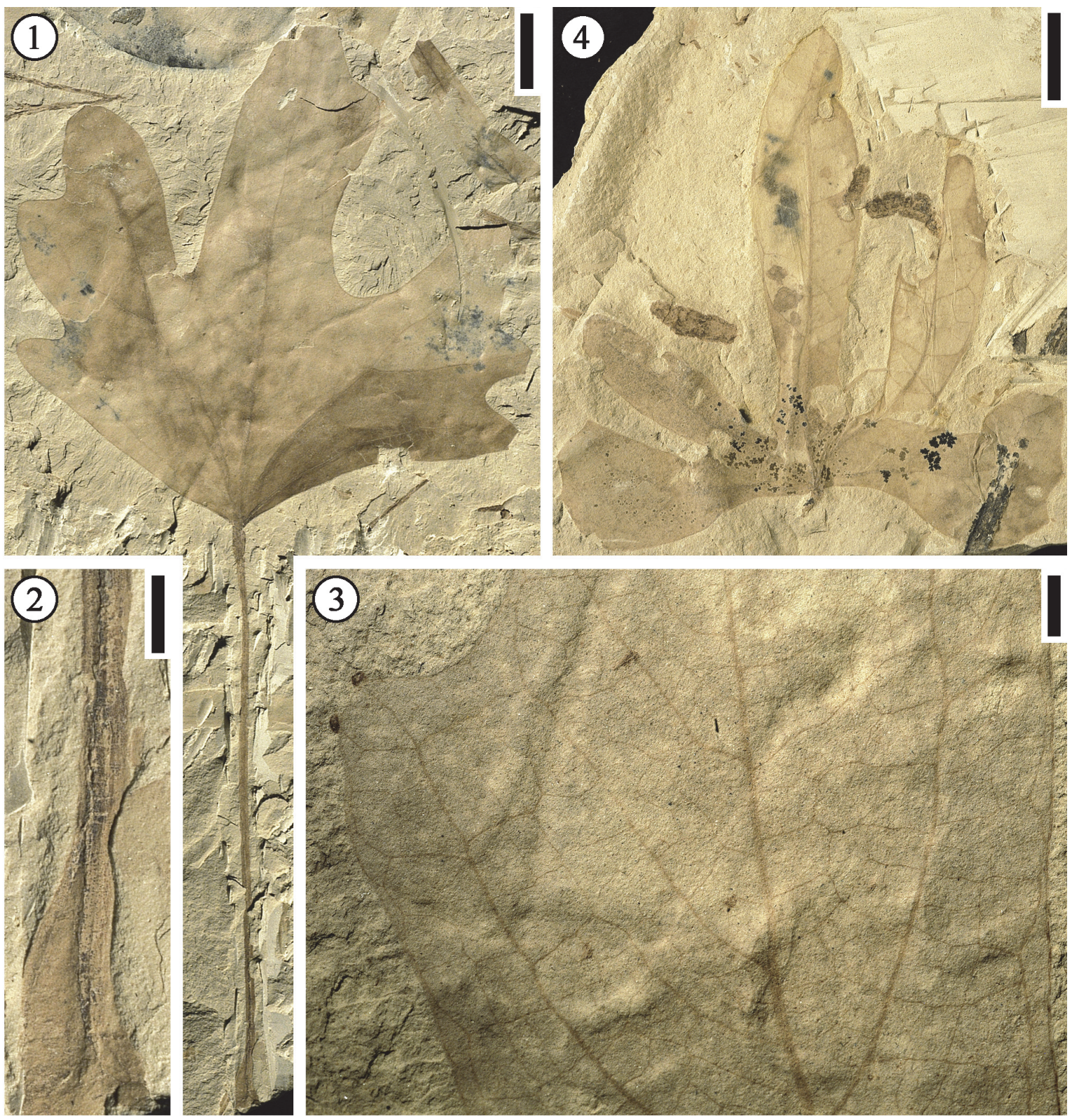

FIGURE 21. Wingia expansolobum (Upchurch and Dilcher) comb. nov. 1, UF15706-30158a, specimen showing a complete leaf. Note the long petiole with a swollen base and the extension of lamina tissue on the petiole. Scale bar equals $1 \mathrm{~cm}$. 2, Enlargement of the petiole in Figure 21.1 to show the swollen base. Scale bar equals $2 \mathrm{~mm}$. 3, UF15706-30158b, enlargement of a leaf on the back of the same specimen to show high order venation and glandular teeth. Scale bar equals $3 \mathrm{~mm}$. 4, UF15706-24788, specimen showing a deeply lobed leaf. Note apically curved outer lateral lobes. Scale bar equals $1 \mathrm{~cm}$.

'V' pattern. Intersecondary veins common, composite, one to three per intercostal region. Tertiary veins orthogonal reticulate, forming predominately quadrangular meshes, tending to be percurrent and arranged at very oblique angles $\left(<20^{\circ}\right)$ with primary veins. Quaternary veins orthogonal reticulate. Veins of higher order not observed.

Number of specimens examined. 52 .
Holotype. UF15713-8304 (designated by Upchurch and Dilcher, 1990).

Specimens illustrated. UF15705-30158 (Figure 21.1-3); 24788 (Figure 21.4); 14825 (Figure 22.12); 24461 (Figure 22.3-4); 14828 (Figure 23.1-3).

Remarks. This species was established by Upchurch and Dilcher (1990) based on one specimen from the Rose Creek I locality, Nebraska. We emend the specific diagnosis because specimens 


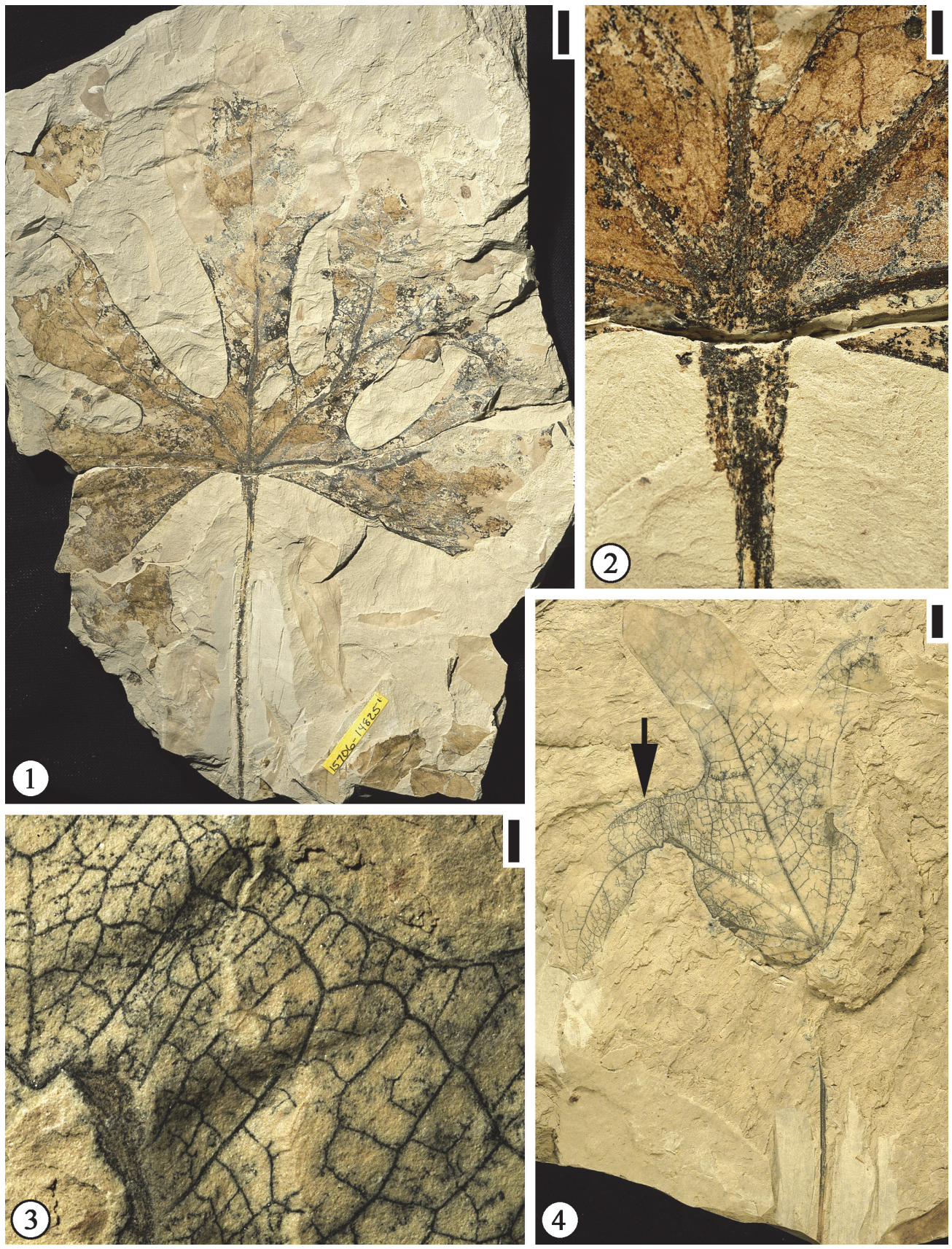

FIGURE 22. Wingia expansolobum (Upchurch and Dilcher) comb. nov. 1, UF15706-14825, specimen showing a large leaf with irregular shape of lateral lobes. Note the structurally reinforced margin on sinus, pluvinus lamina extension on the thin and long petiole. Scale bar equals $1 \mathrm{~cm}$. 2, Enlargement of Figure 22.1 to show the pluvinus lamina extension on the petiole. Scale bar equals $2 \mathrm{~mm}$. 3, UF15706-24461, enlargement of Figure 22.4 (area indicated by arrow) to show looping of secondary veins near the lamina margin. Scale bar equals $1 \mathrm{~mm}$. 4, UF15706-24461, specimen showing a small leaf. Scale bar equals $5 \mathrm{~mm}$.

from the Hoisington III locality yield more information on the leaf features, especially the variations of leaf morphology. For example, secondary venation of Wingia expansolobum can vary from predominately brochidodromous to semicraspedodromous. High order venation (tertiary and quaternary veins) is well preserved on the specimens from the Hoisington III locality, Kansas.

The proximal and distal enlarged areas on the petioles of Wingia expansolobum leaves may be pulvini. In extant plants, the pulvinus, a motor organ for leaf movement (regulating leaf position), 

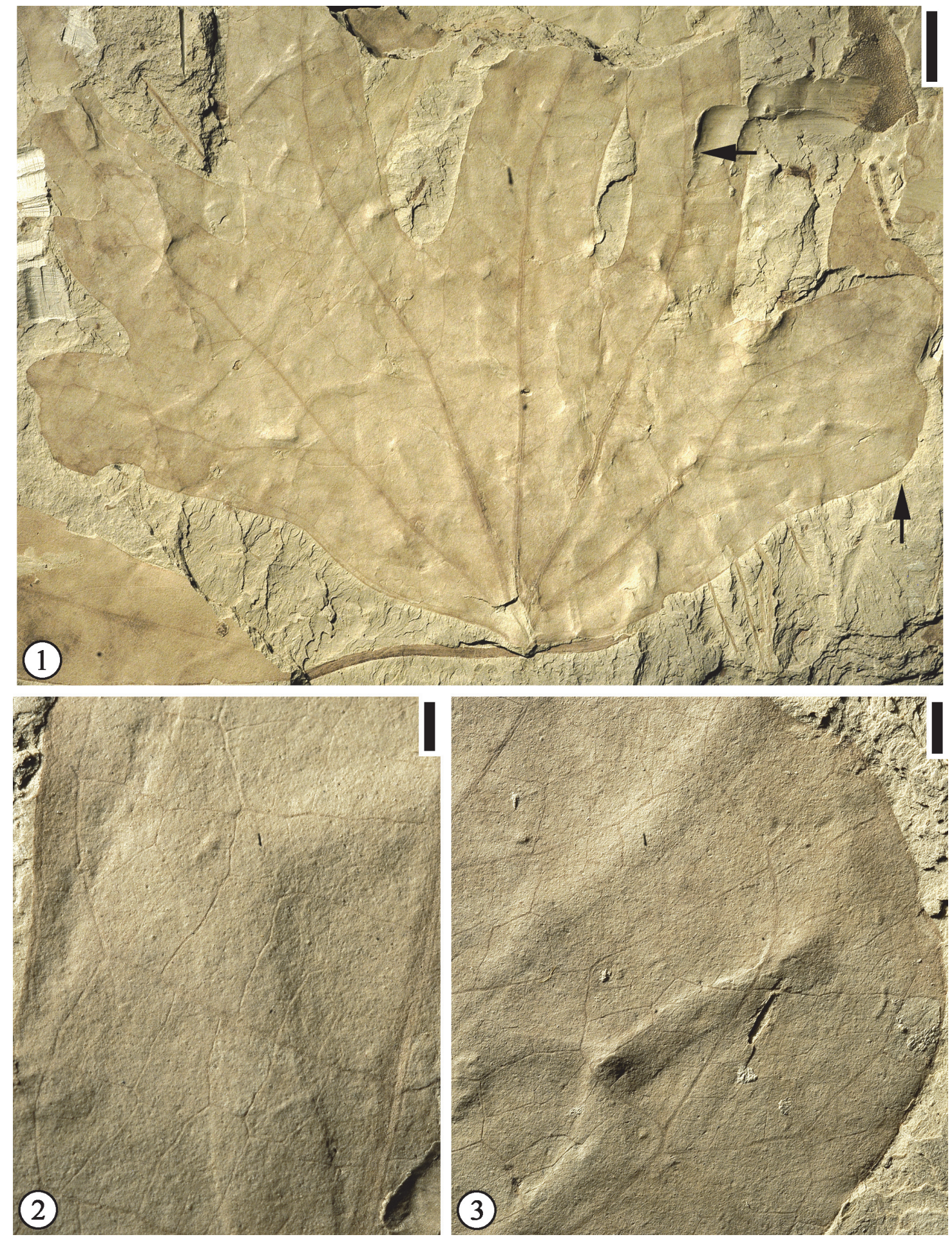

FIGURE 23. Wingia expansolobum (Upchurch and Dilcher) comb. nov. 1, UF15706-14828, specimen showing a multi-lobed leaf. Scale bar equals $1 \mathrm{~cm}$. 2, Enlargement of Figure 23.1 (area indicated by the upper arrow) to show secondary and tertiary venation. Scale bar equals $1 \mathrm{~mm}$. 3, Enlargement of Figure 23.1 (area indicated by the lower arrow) to show venation near the lamina margin. Scale bar equals $2 \mathrm{~mm}$. 
is often found in the Fabaceae (Satter and Morse, 1990; Rodrigues and Machado, 2008). A search using a subset of characters (vegetative morphology and anatomy: leaves [form]) in Intkey (Dallwitz et al., 1995) and using two characters (pulvinate and well-developed leaves) of Wingia expansolobum resulted in 11 families (Averrhoaceae, Barbeuiaceae, Empetraceae, Lardizabalaceae, Leguminosae, Marantaceae, Santalaceae, Sapindaceae, Staphyleaceae, Umbelliferae, and Zygophyllaceae) that have pulvinate leaves. When more characters (including leaf petiolate, simple, palmately-lobed, and primary vein palmate and in this order) are used, only two families, Leguminosae and Umbelliferae, remain. Both families do not seem to have similar leaf morphology as that of Wingia expansolobum. As indicated by Upchurch and Dilcher (1990), no extant species of Magnoliidae has five-lobed organization with basally palmate (actinodromous) primary venation. The modern affinities of Wingia expansolobum remain indeterminate but future collection of specimens with cuticular material may help clear this uncertainty.

Many recent discoveries of the Early Cretaceous fossil leaves with similar tooth pattern have been proposed to be related to the Eudicots. For example, Iterophyllum lobatum Barral et al. (Ranucuales; Barral et al., 2013) is a fossil species based on leaves from the late Barremian of Las Hoyas, Spain. The simple leaf is petiolate and pinnately lobed with chloranthoid-like glands at the lobe apices and the sinuses. Fairlingtonia thyrsopteroides (Fontaine) Jud (Jud, 2015) and Vernifolium tenuiloba Jud and Sohn (Jud and Sohn, 2016) from the Early Cretaceous Potomac Group in Maryland and Virginia, USA were also placed within the Eudicot clade, although their familial and ordinal affinities are unknown.

\section{Wingia cf. expansolobum (Upchurch and Dilcher) comb. nov.}

Figure 24

Description. Leaf simple, five-lobed, leaf $4 \mathrm{~cm}$ long and $8 \mathrm{~cm}$ wide (estimated maximum width); sinus deep, extending $75 \%$ to $80 \%$ of distance from apex to lamina base; medial lobe narrow ovate, symmetrical; lateral lobes asymmetrical, curved apically; apex of lobes obtuse or slightly acute; base of lamina obtusely cuneate or truncate; margin toothed; sinus rounded; serrations minute, simple; serration type ranging from concave to straight on apical side and straight to convex on basal side, spacing irregular; typically three veins entering a tooth, medial vein originating from exmedial side of secondary vein, basal vein tertiary in order and running very close to the margin before entering the tooth, vein of apical side not well developed. Petiole not observed. Primary venation basal actinodromous; primary veins thin, multi-stranded; medial primary vein straight in course; inner lateral primary veins apically curved; outer primary veins apically curved. Secondary venation semicraspedodromous; secondary veins thick relative to primary veins; originating from primary veins at moderate acute angle, slightly curved. One pair of secondary veins in each lobe originating from the extreme base of the leaf lamina and running almost parallel to the primary veins for almost half of the lobe length before joining the secondary veins originated from the primary veins within the lobes. Tertiary veins orthogonal reticulate. Veins of higher order not observed.

Number of species examined. 2.

Specimens illustrated. UF15705-14824 (Figure 24.1, 24.3); 24460 (Figure 24.2).

Remarks. These two specimens are placed in Wingia cf. expansolobum. They differ from Wingia expansolobum in having smaller leaves, relatively thin secondary veins, a pair of distinctive secondary veins originating from the extreme base of the leaf lamina and running parallel to the primary veins for almost half of the lobe length, semicraspedodromous secondary venation, and a predominately toothed margin. Even leaves of the same size (Figure 21.4) of Wingia expansolobum have different venation patterns. We currently separate these two specimens from Wingia expansolobum because of these differences.

\section{Genus DICOTYLOPHYLLUM Saporta, 1894 Dicotylophyllum skogii sp. nov.} Figure 25

Specific diagnosis. Lamina thin. Base cordate. Margin entire. Petiole thin, multi-stranded. Primary venation pinnate; primary vein multi-stranded. Secondary vein thin, decurrent on primary vein, subopposite; angle of divergence moderate acute, uniform. Intersecondary veins common, simple. Tertiary veins thin, originating from secondary or intersecondary veins at right angles, forming rectangular or square meshes that are oriented with long axis parallel to secondary veins.

Description. Observed lamina $11 \mathrm{~cm}$ long and 5 $\mathrm{cm}$ wide; lamina very thin. Base cordate. Observed margin entire. Petiole thin, multi-stranded, $6 \mathrm{~cm}$ long and $1.5 \mathrm{~mm}$ wide. Primary venation pinnate; observed primary vein $1.5 \mathrm{~mm}$ wide, multistranded, slightly curved. Secondary venation not observed; secondary vein thin relative to primary 

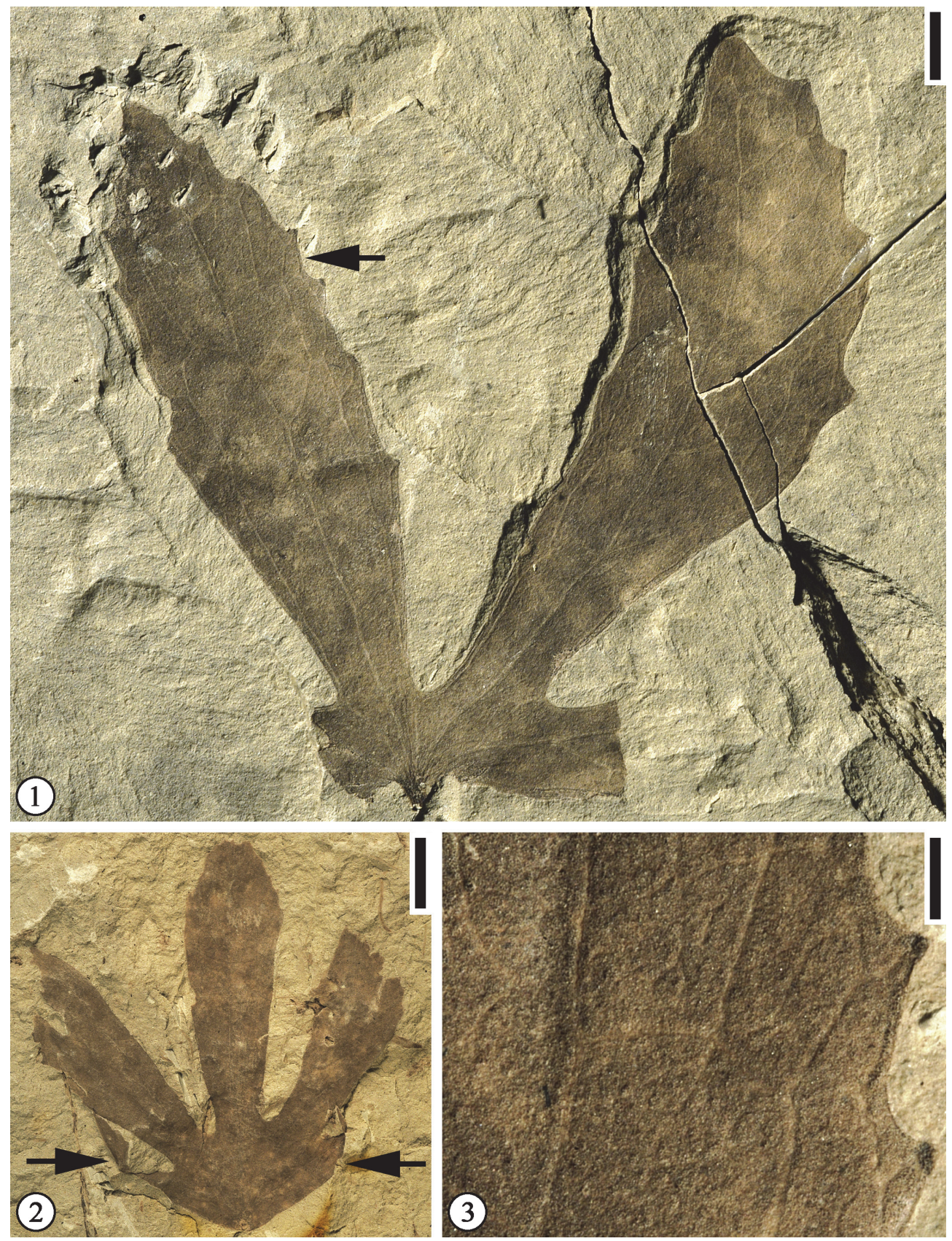

FIGURE 24. Wingia cf. expansolobum (Upchurch and Dilcher) comb. nov. 1, UF15706-14824, specimen showing two complete and two broken lobes. Note thin venation and glandular teeth. Scale bar equals $3 \mathrm{~mm}$. 2, UF15706-24460, specimen showing five lobes. Note that two lobes (indicated by arrows) are broken. Scale bar equals $1 \mathrm{~cm}$. 3 , Enlargement of Figure 24.1 (area indicated by arrow) to show glandular teeth. Scale bar equals $1 \mathrm{~mm}$.

vein, 8 pairs observed, decurrent on primary vein, subopposite; angle of divergence moderate acute (ca. $45^{\circ}$ ), uniform. Intersecondary veins common, simple, 1 to 2 pairs between two adjacent secondary veins. Tertiary veins thin, originating from secondary or intersecondary veins at right angles, forming meshes rectangular or square in shape and oriented with long axis parallel to secondary veins. Veins of higher order not observed.

Number of specimens examined. 1.

Holotype. UF15706-24573 (Figure 25).

Derivation of epithet. In honor of Judith Skog in recognition of her contribution to Dakota paleobotany. 

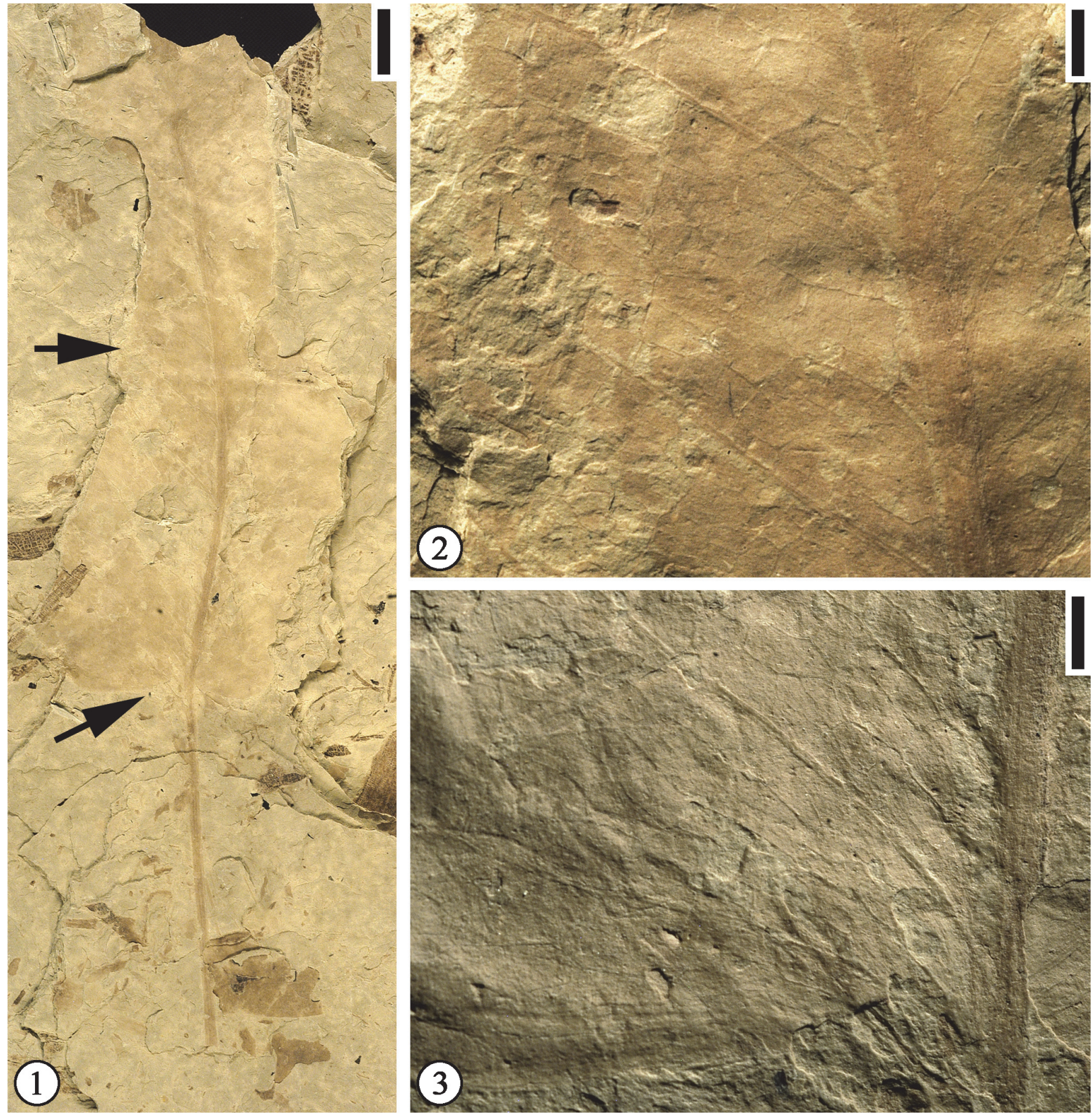

FIGURE 25. Dicotylophyllum skogii sp. nov. 1, UF15706-24573, fragment of leaf to show the petiole and strong primary vein. Scale bar equals $1 \mathrm{~cm}$. 2, Enlargement of Figure 25.1 (area indicated by the upper arrow) to show secondary and intersecondary veins. Scale bar equals $2 \mathrm{~mm}$. 3, Enlargement of the base of the leaf in Figure 25.1 (are indicated by the lower arrow) to show venation. Scale bar equals $2 \mathrm{~mm}$.

Remarks. The observed lamina is $11 \mathrm{~cm}$ long and estimated leaf length may be up to at least $15 \mathrm{~cm}$. Although secondary venation pattern is not observed because of the fragmented nature of the specimen, the combined features of this leaf type, including thin lamina structure, thin primary and higher order veins, large spacing of secondary veins (eight pairs observed on $11 \mathrm{~cm}$ lamina), the presence of intersecondary veins, and tertiary venation patterns is distinctive from any other Dakota Formation angiosperm leaves. The multistranded primary vein and the presence of intersecondary veins indicate its possible affinity within the Magnoliidae. The thin lamina texture, tertiary and quaternary veins forming rectangular meshes with long axes parallel to secondary veins are observed in some extant herbaceous angio- 

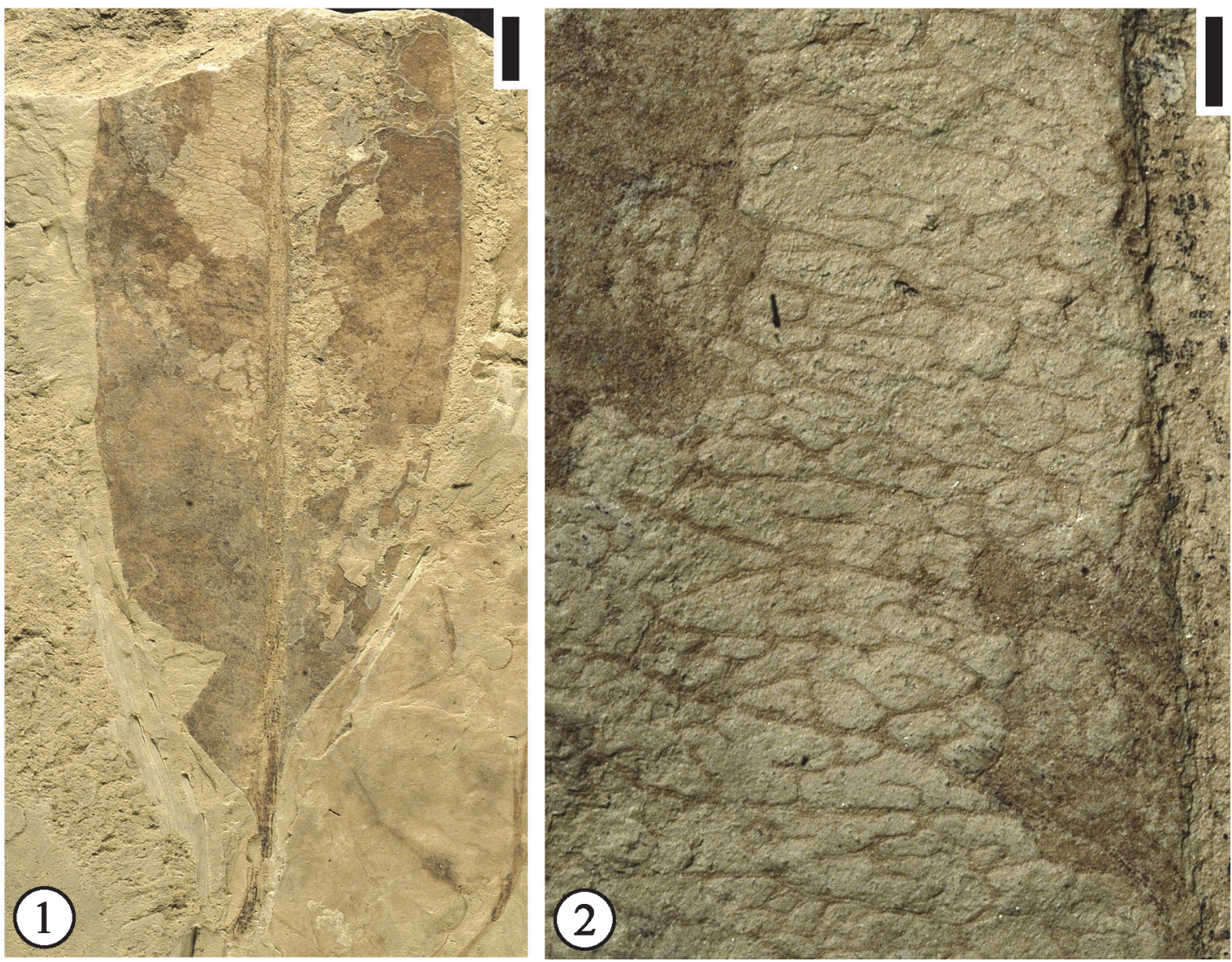

FIGURE 26. Dicotylophyllum leptovenum Wang and Dilcher, 2009. 1, UF15706-24734, incomplete leaf showing strong primary vein and asymmetric lamina base. Scale bar equals $5 \mathrm{~mm}$. 2, Enlargement of Figure 26.1 to show secondary and tertiary veins. Scale bar equals $1 \mathrm{~mm}$.

sperms, indicating that Dicotylophyllum skogii may be an herbaceous plant which grows near water.

Dicotylophyllum leptovenum Wang and Dilcher,
2009

Figure 26

Description. Leaf base asymmetrical. Apex missing. Base acute, decurrent. Margin entire. Petiole short, stout, $1 \mathrm{~cm}$ long and $1.5 \mathrm{~mm}$ wide. Primary venation pinnate; primary vein massive, multistranded, course straight, observed primary vein about $1.2 \mathrm{~mm}$ wide. Secondary venation brochidodromous; secondary veins thin relative to primary vein, 6 pairs observed in a $6 \mathrm{~cm}$ long lamina; secondary veins originating from primary vein at wide acute angle (ca. $70^{\circ}$ ), joining superadjacent secondary veins at a distance of about one fifth of half lamina to enclose an intercostal region; secondary veins uniformly curved, but becoming sinuous when they intersect with intersecondary veins. Intersecondary veins always present, two or three per intercostal region, simple. Tertiary veins course irregular, intersecting with intersecondary veins or randomly reticulate, anastomosing to form meshes irregular in shape and size. Quaternary veins irregular in course, exmedially ramified or forming incompletely closed meshes irregular in shape and size. Veinlets simple, curved. Vein pattern in excostal region not observed.

Number of specimens examined. 1.

Specimens illustrated. UF15706-24734 (Figure 26).

Remarks. The specimen from Hoisington III locality has well-preserved high order veins compared with the specimen from the Courtland I locality, Minnesota.

\section{DISCUSSION}

\section{Vegetation along the East Margin of the Cretaceous Western Interior Seaway (WIS) during the Mid-Cretaceous}

During the latest Albian, angiosperms were widespread and replaced gymnosperms as the 
dominant plants in many environments, as shown at the Hoisington III and other localities (Retallack and Dilcher, 1986). The Hoisington plant fossil assemblage is the best representative of a mixed deposit of several distinct, local plant communities (Retallack and Dilcher, 1981a, 1981b; Retallack and Dilcher, 2012). A swamp woodland vegetation probably included Archaeanthus linnenbergeri (or Liriophyllum kansense; Crane and Dilcher, 1984; Dilcher and Crane, 1984), Lesqueria elocata (Crane and Dilcher, 1984); Caloda delevoryana (Dilcher and Kovach, 1986); Sapindopsis bagleyae, Sapindopsis retallackii, and other members of the Platanaceae; Prisca reynoldsii and members of the Lauraceae, and conifers. Prominent understory plants include ferns, Anemia dicksoniana (Heer) Krassilov, Anemia dakotensis (Rushforth) Skog and Dilcher, Gleichenia camptoniaefolia (Debenham and Ettinghausen) Heer, Gleichenia delicatula Heer, Matonidium brownii Rushforth (Skog and Dilcher, 1994; Hu et al., 2006) and some herbaceous angiosperms (e.g., Skogia leptoselis). Free floating aquatic plants in the open lake water include Marsilea johnhallii (Skog and Dilcher, 1992), Aquatifolia fluitans, and Brasenites kansense (Wang and Dilcher, 2006a). Submerged aquatic plants, e.g., Donlesia dakotensis (Dilcher and Wang, 2009), an extinct member of the Ceratophyllaceae from the coeval Dakota Formation localities, probably also occupied some of the habitat in the fresh water lakes. The semi-aquatic plant, Isoetites phyllophila (Skog and Dilcher, 1994), lived in shallow water or on wet margin that may have experienced short-term drying.

Among all localities from the Dakota Formation, angiosperm leaves are the most species-rich at the Hoisington III locality based on raw counts of species from a collection of 1,500 specimens stored in the Paleobotany collection at the Florida Museum of Natural History. Six species of ferns, one species of quillworts, and six species of conifers have been reported from this locality (Table 3 ). This further confirms the observation that flowering plants were the dominant group in the local floras along the Cretaceous Western Interior Seaway. The abundant conifer pollen in the microfossil record represents the inland and more elevated floras to the east (Retallack and Dilcher, 1986).

\section{Comparisons of Angiosperm Species Richness among Dakota Localities}

Compared with the Braun Ranch locality in Kansas (Wang and Dilcher, 2006a), the Rose Creek locality in Nebraska (Upchurch and Dilcher,
1990), and the Courtland I locality in Minnesota (Wang and Dilcher, 2009), the Hoisington III locality is the most species-rich in angiosperms with 24 species (Table 1). The Hoisington III locality and the Rose Creek I locality share four species, i.e., Crassidenticulum decurrens, Pabiania variloba, Anisodromum wolfei, and Wingia expansolobum. The Hoisington III and Courtland I also have four species in common, i.e., Jarzenia kanbrasota, Rogersia dakotensis Wolfiophyllum pfaffianum, Dicotylophyllum leptovenum, and Credneria cyclophylla. Of the 70 species recognized from the four localities, only one species, i.e., Crassidenticulum decurrens is shared by three localities (Hoisington III, Rose Creek and Braun Ranch). In summary, there is little species overlap between any two localities of the Dakota Formation leaf assemblages. These leaf assemblages are all Dakota time (late Albian to early Cenomanian) equivalent. However, they do not represent floras living at exactly the same time because the deposition of the Dakota Formation extended over at least five million years (Koch and Brenner, 2009). At present, there is no reliable dating of these megafossil localities. Therefore, their relative ages are uncertain. It is not known how the time difference may have affected the diversity pattern of the leaf assemblages among these localities.

\section{Effects of Environments on the Diversity of the Dakota Flora}

Paleoenvironmental interpretation of the four localities by various authors indicates that angiosperm leaf megafossils represent floras that lived under different environments. For example, Farley and Dilcher (1986) interpreted the Braun's Ranch locality as marsh lakeside and the Rose Creek I locality as tidally influenced distributary margin. The Hoisington III locality was interpreted as a fresh water lake or lagoon environment with river influence (Retallack and Dilcher, 1981a, 1981b; Skog and Dilcher, 1992). It has not been possible for us to resolve the relative age of these localities with sufficient precision in order to place them in chronological sequence in the stratigraphic column. This makes it difficult to assess the effects of floristic changes through time on the evolution/ diversity of the Dakota flora. At present, the small number of overlapping species might be explained by the environmental differences at the various localities (Table 1). Similar environments, even though separated by a great geographical distance (or with a great time difference with similar paleoclimate condition, see discussion below), tend to 
TABLE 3. List of quillworts, ferns, and conifers from the Hoisington III locality, Kansas.

\begin{tabular}{|c|c|c|c|}
\hline & Taxa & Organ & References \\
\hline Quillworts & Isoëtites phyllophila Skog, Dilcher and Potter & Rhizome & $\begin{array}{l}\text { Skog et al. (1992), Skog and Dilcher } \\
\text { (1994) }\end{array}$ \\
\hline \multirow[t]{6}{*}{ Ferns } & Anemia dicksoniana (Heer) Krassilov & & Skog and Dilcher (1994) \\
\hline & $\begin{array}{l}\text { Anemia dakotensis (Rushforth) Skog and } \\
\text { Dilcher }\end{array}$ & Leaf & \\
\hline & $\begin{array}{l}\text { Gleichenia camptoniaefolia Debenham and } \\
\text { Ettinghausen) Heer }\end{array}$ & & \\
\hline & Gleichenia delicatula Heer & & \\
\hline & Matonidium brownii Rushforth & & \\
\hline & Marsilea* johnhallii Skog and Dilcher & & $\begin{array}{l}\text { Skog and Hill (1992), Skog and Dilcher } \\
\text { (1994); *Hermsen et al. (2014) } \\
\text { emended the generic name to } \\
\text { Marsileaceaephyllum }\end{array}$ \\
\hline \multirow[t]{6}{*}{ Conifers } & Pinus sp. & Leaf (needle fragments) & Mihai E. Popa (in preparation) \\
\hline & Peltaconus conditus Lesquereux & Seed cone & \\
\hline & ?Pityanthus & Pollen cone & \\
\hline & $\begin{array}{l}\text { Brachyphyllum crassum (Lesquereux) } \\
\text { Lesquereux }\end{array}$ & Leaf & \\
\hline & Geinitzia sp. & & \\
\hline & ?Athrotaxites sp. B & & \\
\hline
\end{tabular}

have more similar taxa than two different environments with a distance of only several kilometers (Kvacek and Dilcher, 2000).

\section{Comparison with the Palynological Record}

The high diversity of angiosperm leaf megafossils at different localities is in conflict with the microfossil record (Farley and Dilcher, 1986; Dilcher and Farley, 1988), which indicates a high percentage of non-angiosperm palynomorph abundance. This was interpreted as resulting from the dominance of ferns and gymnosperms in the upland and coastal regional floras and the dominance of angiosperms in local coastal environments (Skog and Dilcher, 1994; Kvacek and Dilcher, 2000). It has also been suggested that the Dakota Formation was formed at a time just prior to the development of wind dispersed angiosperm pollen (Kvacek and Dilcher, 2000). All these suggest that the high diversity of angiosperms from different localities is controlled by environment, rather than being a sampling effect (Farley and Dilcher, 1986), which further suggests successful competition of angiosperms in coastal environments with gymnosperms and ferns during that time (Retallack and Dilcher, 1986; Kvacek and Dilcher, 2000).

\section{CONCLUSIONS}

In this report, we recognize 24 fossil leaf species from the Hoisington III locality, Kansas, USA. This leaf assemblage represents the highest species richness of the four Dakota Formation localities (Braun Ranch and Hoisington III, Kansas, Courtland I, Minnesota, and Rose Creek, Nebraska). So far, a total of 70 fossil leaf species have been recognized from these four localities (Table 1). There is little overlap of angiosperm leaf species between any two Dakota Formation localities. At present, the high diversity of angiosperms that is locality specific and the little species overlap between any two Dakota Formation localities can best be interpreted as the evolution of angiosperm diversity, each being unique to the different environments in which they grew (Retallack and Dilcher, 1986).

\section{ACKNOWLEDGMENTS}

This paper represents a portion of HW's dissertation submitted to the Graduate School at the University of Florida in partial fulfillment of the requirements of a doctoral degree. HW thanks his Ph.D. supervisory committee members D. Dilcher, W. Judd, S. Manchester, E. Martin, N. Opdyke, and A. Randazzo for their support. HW would like to acknowledge the Department of Geological Sciences, the Graduate Student Council of the Stu- 
dent Government, the College of Liberal Arts and Sciences, the Graduate School at the University of Florida, the Geological Society of America, the Dilcher-Beck Paleobotany fund, and the Botanical Society of America (Paleobotanical Section) for travel support to present the research results at different professional meetings. We thank $\mathrm{S}$. Wing
(National Museum of Natural History) for access to Lesquereux's type and other Dakota Formation specimens and J. Blanchard and C. Sanders for proofreading the manuscript. This project was partially supported by National Science Foundation grants (DEB 73-10720; BSR 83-00476; BSR 8616657) to DLD.

\section{REFERENCES}

Angiosperm Phylogeny Group. 2009. An update of the Angiosperm Phylogeny Group classification for the orders and families of flowering plants: APG III. Botanical Journal of the Linnean Society, 161:105-121. https://doi.org/10.1111/j.1095-8339.2009.00996.x

Angiosperm Phylogeny Group. 2016. An update of the Angiosperm Phylogeny Group classification for the orders and families of flowering plants: APG IV. Botanical Journal of the Linnean Society, 181:1-20. https://doi.org/10.1111/boj.12385

Barclay, R.S., Johnson, K.R., Betterton, W.J., and Dilcher, D.L. 2003. Stratigraphy and megaflora of a K-T boundary section in the eastern Denver Basin. Rocky Mountain Geology, 38:45-71. https://doi.org/10.2113/gsrocky.38.1.45

Barral, A., Gomez, B., Feild, T.S., Coiffard, C., and Daviero-Gomez, V. 2013. Leaf architecture and ecophysiology of an early basal eudicot from the Early Cretaceous of Spain. Botanical Journal of the Linnean Society, 173:594-605. https://doi.org/10.1111/boj.12095

Berry, E.W. 1902. Notes on the phylogeny of Liriodendron. Botanical Gazette, 34:44-63.

Berry, E.W. 1909. Contributions to the Mesozoic flora of the Atlantic coastal plain - III. Bulletin of the Torrey Botanical Club, 36:245-264. https://doi.org/10.2307/2479310

Berry, E.W. 1911a. Contributions to the Mesozoic flora of the Atlantic coastal plain - VII. Bulletin of the Torrey Botanical Club, 38:399-424. https://doi.org/10.2307/2479244

Berry, E.W. 1911b. The Lower Cretaceous of Floras of the World, p. 99-151. In Clark, W.B. (ed.), Lower Cretaceous. Johns Hopkins Press, Baltimore.

Berry, E.W. 1911c. Correlation of the Potomac Formations, p. 153-172. In Clark, W.B. (ed.), Lower Cretaceous. Johns Hopkins Press, Baltimore.

Berry, E.W. 1911d. Systematic paleontology of the Lower Cretaceous deposits of Maryland: plants, p. 214-508. In Clark, W.B. (ed.), Lower Cretaceous. Johns Hopkins Press, Baltimore.

Berry, E.W. 1916. The Upper Cretaceous Floras of the World, p. 183-313. In Clark, W.B. (ed.), Upper Cretaceous. Johns Hopkins Press, Baltimore.

Berry, E.W. 1920. The age of the Dakota flora. American Journal of Science (Series 4), 50:387390. https://doi.org/10.2475/ajs.s4-50.299.387

Berry, E.W. 1922a. The flora of the Woodbine Sand at Arthurs Bluff, Texas. U.S. Geological Survey Professional Paper, 129:153-182.

Berry, E.W. 1922b. The flora of the Cheyenne Sandstone of Kansas. U.S. Geological Survey Professional Paper, 129:199-225.

Berry, E.W. 1923. Tree Ancestors: A Glimpse into the Past. Williams and Wilkins Co., Baltimore.

Blume, C.L. 1830. Schisandraceae. Flora Javae, 3:32-33.

Brenner, R.L., Ludvigson, G.A., Witzke, B.J., Zawistoshi, A.N., Kvale, E.P., Ravn, R.L., and Joeckel, R.M. 2000. Late Albian Kiow-Skull Creek marine transgression, Lower Dakota Formation, eastern margin of Western Interior Seaway, U.S.A. Journal of Sedimentary Research, 70:868-878. https://doi.org/10.1306/2DC4093E-0E47-11D7-8643000102C1865D

Brown, R.W. 1933. Fossil plants from the Aspen Shale of southwestern Wyoming. Proceedings of the United States National Museum, 82:1-10. https://doi.org/10.5479/si.00963801.822953.1

Brown, R.W. 1962. Paleocene Flora of the Rocky Mountains and Great Plains. U.S. Geological Survey Professional Paper, 375:1-119.

Crane, P.R. 1989. Paleobotanical evidence on the early radiation of nonmagnoliid dicotyledons. Plant Systematics and Evolution, 162:165-191. https://doi.org/10.1007/BF00936916 
Crane, P.R. and Dilcher, D.L. 1984. Lesqueria: an early angiosperm fruiting axis from the MidCretaceous. Annals of the Missouri Botanical Garden, 71:384-402. https://doi.org/10.2307/ 2399031

Dallwitz, M.J., Paine, T.A., and Zurcher, E.J. 1995 Onwards. User's Guide to Intkey: a Program for Interactive Identification and Information Retrieval. http://delta-intkey.com.

de Jussieu, A.L. 1789. Genera Plantarum, Secundum Ordines Naturales Disposita Juxta Methodum in Horto Regio Parisiensi Exaratam. Herissant \& Barrois, Paris. https://doi.org/ 10.5962/bhl.title.7762

Dilcher, D.L. 1974. Approaches to the identification of angiosperm leaf remains. Botanical Review, 40:1-157. https://doi.org/10.1007/BF02860067

Dilcher, D.L. 1979. Early angiosperm reproduction: an introductory report. Review of Palaeobotany and Palynology, 27:291-328. https://doi.org/10.1016/0034-6667(79)90015-0

Dilcher, D.L. 2000. Toward a new synthesis: Major evolutionary trends in the angiosperm fossil record. Proceedings of the National Academy of Sciences USA, 97(13):7030-7036. https:// doi.org/10.1073/pnas.97.13.7030

Dilcher, D.L. and Basson, P.W. 1990. Mid-Cretaceous angiosperm leaves from a new fossil locality in Lebanon. Botanical Gazette, 151:538-547.

Dilcher, D.L. and Crane, P.R. 1984. Archaeanthus: an early angiosperm from the Cenomanian of the Western Interior of North America. Annals of the Missouri Botanical Garden, 71:351-383. https://doi.org/10.2307/2399030

Dilcher, D.L. and Farley, M.B. 1988. Cenomanian miospores and co-occurring megafossils in the mid-continent of North America, p. 39. In (editor unknown), 7th International Palynological Congress (Abstract). (Publisher unknown), Brisbane.

Dilcher, D.L. and Kovach, W.L. 1986. Early angiosperm reproduction: Caloda delevoryana gen. et sp. nov., a new fruitification from the Dakota Formation (Cenomanian) of Kansas. American Journal of Botany, 73:1230-1237. https://doi.org/10.1002/j.15372197.1986.tb08570.x

Dilcher, D.L. and Wang, H. 2009. An Early Cretaceous fruit with affinities to Ceratophyllaceae. American Journal of Botany, 96:2256-2269. https://doi.org/10.3732/ajb.0900049

Doyle, J.A. and Hickey, L.J. 1976. Pollen and leaves from the mid-Cretaceous Potomac Group and their bearing on early angiosperm evolution, p. 139-206. In Beck, C.B. (ed.), Origin and Early Evolution of Angiosperms. Columbia University Press, New York.

Doyle, J.A. and Hotton, C.L. 1991. Diversification of early angiosperm pollen in a cladistic context, $\quad$ p. 169-195. In Blackmore, S. and Barnes, S.H. (eds.), Pollen and Spores: Patterns of Diversification. Clarendon Press, Oxford.

Ellis, B., Daly, D.C., Hickey, L.J., Johnson, K.K., Mitchell, J.D., Wilf, P., and Wing, S.L. 2009. Manual of Leaf Architecture. Cornell University Press, Ithaca.

Estrada-Ruiz, E., Upchurch, G.R., Wolfe, J.A., and Cevallos-Ferriz, S.R.S. 2011. Comparative morphology of fossil and extant leaves of Nelumbonaceae, including a new genus from the Late Cretaceous of western North America. Systematic Botany, 36:337-351. https://doi.org/ 10.1600/036364411X569525

Farley, M.B. and Dilcher, D.L. 1986. Correlation between miospores and depositional environments of the Dakota Formation (mid-Cretaceous) of north central Kansas and adjacent Nebraska, U.S.A. Palynology, 10:117-133. https://doi.org/10.1080/ 01916122.1986.9989306

Fontain, W.M. 1889. The Potomac of younger Mesozoic Flora. U.S. Geological Survey Monograph, 15:1-377.

Gandolfo, M.A. and Cúneo, R.N. 2005. Fossil Nelumbonaceae from the La Colonia Formation (Campanian-Maastrichtian, Upper Cretaceous), Chubut, Patagonia, Argentina. Review of Palaeobotany and Palynology, 133:169-178. https://doi.org/10.1016/j.revpalbo.2004.09.007

Golovneva, L.B. 2007. Occurrence of Sapindopsis (Platanaceae) in the Cretaceous of Eurasia. Paleontological Journal, 41:1077-1090. https://doi.org/10.1134/S003103010711007X

Guo, S.X. 2011. The Late Miocene Bangmai flora from Lincang County of Yunnan, southwestern China. Acta Palaeontologica Sinica, 50:353-408.

Halamski, A.T. 2013. Latest Cretaceous leaf floras from southern Poland and western Ukraine. Acta Palaeontologica Polonica, 58(2):407-443. http://dx.doi.org/10.4202/app.2011.0024

Harris, E.B. and Arens, N.C. 2016. A mid-Cretaceous angiosperm-dominated macroflora from the Cedar Mountain Formation of Utah, USA. Journal of Paleontology, 90:640-662. https:// doi.org/10.1017/jpa.2016.44 
Heer, O. 1883. Die fossile Flora der Polarländer. Flora Fossilis Arctica, 7:1-275.

Herman, A.B., Golovneva, L.B., Shczepetov, S.V., and Grabovsky, A.A. 2016. The Late Cretaceous Arman Flora of Magadan Oblast, Northeastern Russia. Stratigraphy and Geological Correlation, 24:651-760. https://doi.org/10.1134/S0869593816070029

Herman, A.B. and Kvaček, J. 2007a. Early Campanian Grünbach flora of Austria: Systematic composition and palaeoclimatic interpretations. Acta Palaeobotanica, 47:37-55.

Herman, A.B. and Kvaček, J. 2007b. Early Campanian Grünbach Flora of Austria. Paleontological Journal, 41:1068-1076. https://doi.org/10.1134/S0031030107110068

Herman, A.B. and Kvaček, J. 2010. Late Cretaceous Grünbach Flora of Austria. Naturhistorisches Museum, Wien.

Hermsen, E.J., Gandolfo, M.A., and Cuneo, N. R. 2014. New marsileaceous fossils from the Late Cretaceous of South America and a reevaluation of Marsileaceaephyllum. Plant Systematics and Evolution, 300:369-386. https://doi.org/10.1007/s00606-013-0886-7

Hickey, L.J. 1973. Classification of the architecture of dicotyledonous leaves. American Journal of Botany, 60:17-33. https://doi.org/10.1002/j.1537-2197.1973.tb10192.x

Hickey, L.J. 1979. A revised classification of the architecture of dicotyledonous leaves, p. 25-39. In Metcalfe, C.R. and Chalk, L. (eds.), Anatomy of the Dicotyledons: Systematic Anatomy of the Leaf and Stem, with a Brief History of the Subject. Clarendon Press, Oxford.

Hickey, L.J. and Doyle, J.A. 1977. Early Cretaceous evidence for angiosperm evolution. Botanical Review (Lancaster), 43:3-104. https://doi.org/10.1007/BF02860849

Hickey, L.J. and Wolfe, J.A. 1975. The bases of angiosperm morphology: vegetative morphology. Annals of the Missouri Botanical Garden, 62:538-589. https://doi.org/10.2307/2395267

Hu, S., Dilcher, D.L., Schneider, H., and Jarzen, D.M. 2006. Eusporangiate ferns from the Dakota Formation, Minnesota, USA. International Journal of Plant Sciences, 167:579-589. https://doi.org/10.1086/501235

Huang, Q.C. and Dilcher, D.L. 1994. Evolutionary and paleoecological implications of fossil plants from the Lower Cretaceous Cheyenne Sandstone of the Western Interior, p. 129-144. In Shurr, G.W., Ludvigson, G.A., and Hammond, R.H. (eds.), Perspectives on the Eastern Margin of the Cretaceous Western Interior Basin. Geological Society of America Special Paper 287. Geological Society of America, Boulder. https://doi.org/10.1130/SPE287-p129

Johnson, K.R. 2002. Megaflora of the Hell Creek and lower Fort Union Formations in the western Dakotas; Vegetational response to climate change, the Cretaceous-Tertiary boundary event, and rapid marine transgression, p. 329-391. In Hartman, H.H., Johnson, K.R., and Nichols, D.J. (eds.), The Hell Creek Formation and the Cretaceous-Tertiary Boundary in the Northern Great Plains: An Integrated Continental Record of the End of the Cretaceous. Geological Society of America, Boulder. https://doi.org/10.1130/0-8137-2361-2.329

Jud, N.A. 2015. Fossil evidence for a herbaceous diversification of early eudicot angiosperms during the Early Cretaceous. Proceedings of the Royal Society B: Biological Sciences, 282:20151045. http://dx.doi.org/10.1098/rspb.2015.1045

Jud, N.A. and Sohn, J.C. 2016. Evidence for an ancient association between leaf mining flies and herbaceous eudicot angiosperms. Cretaceous Research, 63:113-121. https://doi.org/ 10.1016/j.cretres.2016.02.019

Knowlton, F.H. 1919. A Catalogue of the Mesozoic and Cenozoic Plants of North America. Government Printing Office, Washington, D.C.

Knowlton, F.H. 1922. The Laramie flora of the Denver Basin with a review of the Laramie problem. U.S. Geological Survey Professional Paper, 130:1-175.

Knowlton, F.H. 1930. The flora of the Denver and associated formations of Colorado. U.S. Geological Survey Professional Paper, 155:1-142.

Koch, J.T. and Brenner, R.L. 2009. Evidence for glacioeustatic control of large, rapid sea-level fluctuations during the Albian-Cenomanian: Dakota Formation, eastern margin of Western Interior Seaway. Cretaceous Research, 30:411-423. https://doi.org/10.1016/ j.cretres.2008.08.002

Krassilov, V.A. and Bacchia, F. 2000. Cenomanian florule of Nammoura, Lebanon. Cretaceous Research, 21:785-799. https://doi.org/10.1006/cres.2000.0229

Kvacek, J. and Dilcher, D.L. 2000. Comparison of Cenomanian Floras from Western Interior North America and Central Europe. Acta Universitatis Carolinae-Geologica, 44(1):7-38.

Lesquereux, L. 1868. On some Cretaceous fossil plants from Nebraska. American Journal of Science (Series 2), 46:91-105. https://doi.org/10.2475/ajs.s2-46.136.91 
Lesquereux, L. 1871. Fossil flora, p. 281-318. In Hayden, F.V. (ed.), U.S. Geological Survey of Montana and Portions of Adjacent Territories, 5th Annual Report, Part III. Government Printing Office, Washington D.C.

Lesquereux, L. 1872. Enumeration and description of the fossil plants from the specimens obtained in the explorations of Dr. F.V. Hayden, 1870 and 1871. II. Remarks on the Cretaceous species described above. Annual Report of the United States Geological and Geographical Survey of the Territories, 5:283-303.

Lesquereux, L. 1873. Lignitic formation and fossil flora. Annual Report of the United States Geological and Geographical Survey of the Territories, 6:317-427.

Lesquereux, L. 1874. Contributions to the fossil flora of the Western Territories. Part I. The Cretaceous flora. U.S Geological and Geographical Survey Territory Annual Report, 6:1-136.

Lesquereux, L. 1876a. On the Tertiary flora of the North American lignite, considered as evidence of the age of the formation. Annual Report of the United States Geological and Geographical Survey of the Territories, 8:273-315.

Lesquereux, L. 1876b. A review of the Cretaceous flora of North America. Annual Report of the United States Geological and Geographical Survey of the Territories, 8:316-365

Lesquereux, L. 1878. Remarks on specimens of Cretaceous and Tertiary plants secured by the survey in 1877, with a list of species hitherto described. p. 481-520. In Hayden, F.V. (ed.), Tenth Annual Report of the United States Geological and Geographical Survey of the Territories. Government Printing Office, Washington D.C.

Lesquereux, L. 1883. Contributions to the fossil flora of the Western Territories. Part 3. The Cretaceous and Tertiary floras. U.S. Geological and Geographical Survey Territory Annual Report, 8:1-283.

Lesquereux, L. 1892. The flora of the Dakota Group. U.S. Geological Survey Monograph, $17: 400$.

Lesquereux, L. 1893. Cretaceous fossil plants from Minnesota. Geological and Natural History Survey of Minnesota, 3:1-22.

Lestiboudois, T. 1826. Botanographie Élémentaire ou Principes de Botanique, D’Anatomie et de Physiologie Végétable. Roret, Paris.

Matsuo, H. 1954. Discovery of Nelumbo from the Asuwa flora (Upper Cretaceous) in Fukui prefecture in the inner side of central Japan. Transactions and Proceedings of the Palaeontological Society of Japan, 14:155-158.

Matsuo, H. 1962. A study on the Asuwa Flora (Late Cretaceous age) in the Hokuriku District, Central Japan. Science Reports of Kanazawa University, 8:177-250.

Matthews, S.C. 1973. Notes on open nomenclature and on synonymy lists. Palaeontology, 16:713-719.

McNeill, J., Barrie, F.R., Buck, W.R., Demoulin, V., Greuter, W., Hawksworth, D.L., Herendeen, P.S., Knapp, S., Marhold, K., Prado, J., Prud'homme van Reine, W.F., Smith, G.F., and Wiersema, J.H. 2012. International Code of Nomenclature for Algae, Fungi, and Plants (Melbourne Code), Adopted by the Eighteenth International Botanical Congress Melbourne, Australia, July 2011. Koeltz Scientific Books, Königstein.

Mohr, B.A.R., Bernardes-de-Oliveira, M.E.C., and Taylor, D.W. 2008. Pluricarpellatia, a nymphaealean angiosperm from the Lower Cretaceous of northern Gondwana (Crato Formation, Brazil). Taxon, 57:1147-1158.

Newberry, J.S. 1868. Notes on the later extinct floras of North America, with descriptions of some new species of fossil plants from the Cretaceous and Tertiary strata. Annals of the Lyceum of Natural History of New York, 9:1-76. https://doi.org/10.1111/j.17496632.1870.tb00175.x

Newberry, J.S. 1895. The flora of the Amboy Clays. Monographs of the United States Geological Survey, 26:1-260.

Newberry, J.S. 1898. The later extinct floras of North America. Monographs of the United States Geological Survey, 35: 1-151.

Pan, A.D. 2010. Rutaceae leaf fossils from the Late Oligocene (27.23 Ma) Guang River flora of northwestern Ethiopia. Review of Palaeobotany and Palynology, 159:188-194. https:// doi.org/10.1016/j.revpalbo.2009.12.005

Perleb, K.J. 1826. Lehrbuch der Naturgeschichte des Pflanzenreichs. Magner, Friburgo, Alemaña.

Retallack, G. and Dilcher, D.L. 1981a. A coastal theory of flowering plant origin, p. 27-77. In Niklas, K.J. (ed.), Paleobotany, Paleoecology, and Evolution. Praeger Publishers, New York. 
Retallack, G.J. and Dilcher.D.L. 1981b. Early angiosperm reproduction: Prisca reynoldsii gen. et sp. nov. from mid-Cretaceous coastal deposits in Kansas, USA. Palaeontographica, Abteilung B, 179:103-137.

Retallack, G.J. and Dilcher, D.L. 1986. Cretaceous angiosperm invasion of North America. Cretaceous Research, 7:227-252. https://doi.org/10.1016/0195-6671(86)90027-3

Retallack, G.J. and Dilcher, D.L. 2012. Outcrop versus core and geophysical log interpretation of mid-Cretaceous paleosols from the Dakota Formation of Kansas. Palaeogeography, Palaeoclimatology, Palaeoecology, 329-330:47-63. https://doi.org/10.1016/ j.palaeo.2012.02.017

Richard, A. 1822. Cabomba. Dictionnaire Classique D'Historie Naturelle, 2:607-608.

Rodrigues, T.M. and Machado, S.R. 2008. Pulvinus functional traits in relation to leaf movements: a light and transmission electron microscopy study of the vascular system. Micron, 39:7-16. https://doi.org/10.1016/j.micron.2007.09.001

Romanov, M.S. and Dilcher, D.L. 2013. Fruit structure in Magnoliaceae s.I. and Archaeanthus and their relationships. American Journal of Botany, 100:1494-1508. https://doi.org/10.3732/ ajb.1300035

Salisbury, R.A. 1805. Description of the natural order of Nymphaeaceae. Annals of Botany (König \& Sims), 2:69-76.

Saporta, G.D. 1894. Flore fossile du Portugal. Nouvelles contributions à la flore Mésozoique. Accompangnées d'une notice stratigraphique par Paul Choffat. Imprimerie del'Academie Royale des Sciences, Lisbon.

Satter, R.L. and Morse, M.J. 1990. Light modulated circadian rhythmic leaf movements in nyctinastic legumes, p. 10-24. In Satter, R.L., Gorton, H.L., and Vogelmann, T.C. (eds.), The Pulvinus: Motor Organ for Leaf Movement. American Society of Plant Physiologists, Rockville.

Setterholm, D.R. 1994. The Cretaceous rocks of southwestern Minnesota: Reconstructions of a marine to nonmarine transition along the eastern margin in the Western Interior Seaway, $p$. 97-110. In Shurr, G.W., Ludvigson, G.A., and Hammond, R.H. (ed.), Perspectives on the Eastern Margin of the Cretaceous Western Interior Basin. Geological Society of America, Boulder. https://doi.org/10.1130/spe287-p97

Sims, J. 1820. Chloranthus monostachys. One-spiked Chloranthus, or Chu-lan. Curtis's Botanical Magazine, 48:2190.

Skog, J. and Dilcher, D. 1994. Lower vascular plants of the Dakota Formation in Kansas and Nebraska, USA. Review of Palaeobotany and Palynology, 80:1-18. https://doi.org/10.1016/ 0034-6667(94)90089-2

Skog, J., Dilcher, D., and Potter, F. 1992. A new species of Isoëtites from the Mid-Cretaceous Dakota Group of Kansas and Nebraska. American Fern Journal, 82:151-161. https://doi.org/ $10.2307 / 1547528$

Skog, J. and Hill, C. 1992. The Mesozoic herbaceous Lycopsids. Annals of the Missouri Botanical Garden, 79:648-675. https://doi.org/10.2307/2399758

Smith, A.C. 1947. The families Illiciaceae and Schisandraceae. Sargentia, 7:1-224.

Taylor, D.W., Brenner, G.J., and Basha, S.H. 2008. Scutifolium jordanicum gen. et sp. nov. (Cabombaceae), an aquatic fossil plant from the Lower Cretaceous of Jordan, and the relationships of related leaf fossils to living genera. American Journal of Botany, 95:340-352. https://doi.org/10.3732/ajb.95.3.340

Taylor, D.W. and Gee, C.T. 2014. Phylogenetic analysis of fossil water lilies based on leaf architecture and vegetative characters: testing phylogenetic hypotheses from molecular studies. Bulletin of the Peabody Museum of Natural History, 55(2):89-110. https://doi.org/ 10.3374/014.055.0208

Upchurch, G.R. 1984. Cuticle evolution in early Cretaceous angiosperms from the Potomac Group of Virginia and Maryland. Annals of the Missouri Botanical Garden, 71:522-550. https:/ /doi.org/10.2307/2399036

Upchurch, G.R., Crane, P.R., and Drinnan, A.N. 1994. The megaflora from the Quantico locality (upper Albian), Lower Cretaceous Potomac Group of Virginia. Virginia Museum of Natural History Memoir, 4:1-57.

Upchurch, G.R. and Dilcher, D.L. 1990. Cenomanian angiosperm leaf megafossils from the Rose Creek locality of the Dakota Formation, southeastern Nebraska. U.S. Geological Survey Bulletin, 1915:1-55.

von Berchtold, F.G. and Presl, J.S. 1820. O prirozenosti Rostlin. K.W. Endersa, Praha. 
Wang, H. and Dilcher, D.L. 2006a. Early Cretaceous angiosperm leaves from the Dakota Formation, Braun Ranch locality, Kansas, USA. Palaeontographica Abteilung B, 273:101137.

Wang, H. and Dilcher, D.L. 2006b. Aquatic angiosperms from the Dakota Formation (Albian, Lower Cretaceous), Hoisington III locality, Kansas, USA. International Journal of Plant Sciences, 167:385-401. https://doi.org/10.1086/499502

Wang, H. and Dilcher, D.L. 2009. Late Cretaceous angiosperm leaves from the Courtland clay pit, Minnesota, USA. Palaeontographica Abteilung B, 281:143-177. https://doi.org/10.1127/ palb/281/2009/143

Wang, H., Dilcher, D.L., Schwarzwalder, R.N., and Kvaček, Y. 2011. Vegetative and reproductive morphology of an extinct Early Cretaceous member of Platanaceae from the Braun's Ranch locality, Kansas, U.S.A. International Journal of Plant Sciences, 172:139-157. https://doi.org/ 10.1086/657281

Witzke, B.J. and Ludvigson, G.A., 1996. Mid-Cretaceous fluvial deposits of the Eastern Margin, Western Interior Basin: Nishnabotna Member, Dakota Formation-a field guide to the Cretaceous of Guthrie County. Geological Society Guide Book Series, 17:1-75.

Wolfe, J.A., Doyle, J.A., and Page, V.M. 1975. The bases of angiosperm phylogeny: paleobtany. Annals of the Missouri Botanical Garden, 62:801-824. https://doi.org/10.2307/2395274

Xie, S.P., Manchester, S.R., Liu, K.N., Wang, Y.F., and Sun, B.N. 2013. Citrus linczangensis sp. n., a Leaf Fossil of Rutaceae from the Late Miocene of Yunnan, China. International Journal of Plant Sciences, 174:1201-1207. https://doi.org/10.1086/671796

Zenker, J.C. 1833. Beitrage zur Naturgeschichte der Urwelt. Organische Reste (Petrefacten) aus der Altenburger Braunkohlen-formation, dem Blankenburger Quadersandstein, jenaischen bunten Sandstein und bhmischen bergangsgebirge. Druck und Verlay von Friedrich Manuke, Jena. 